
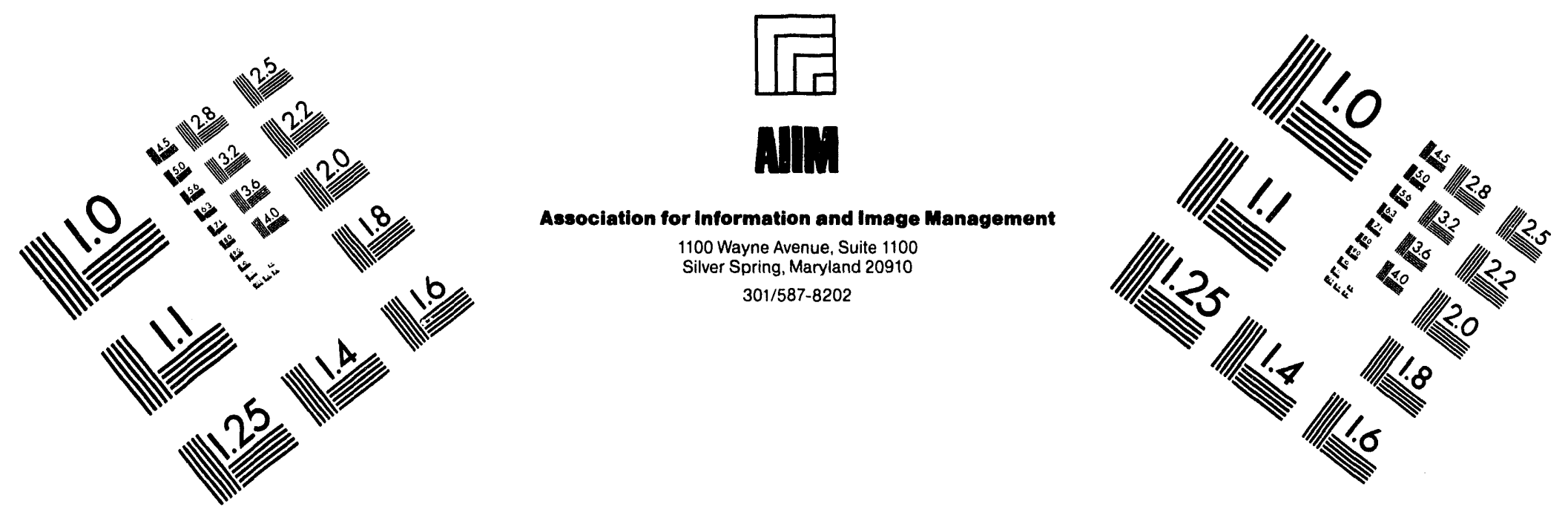

\title{
Centimeter
}

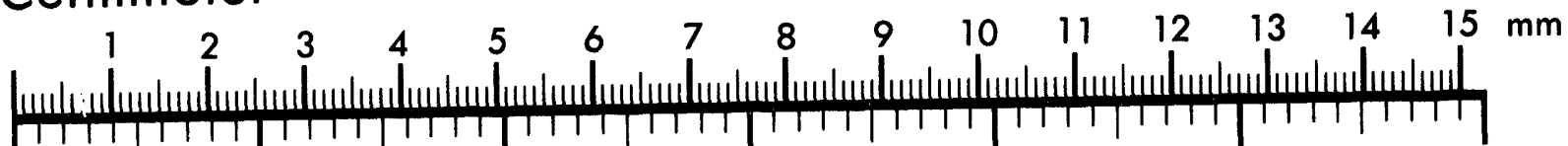

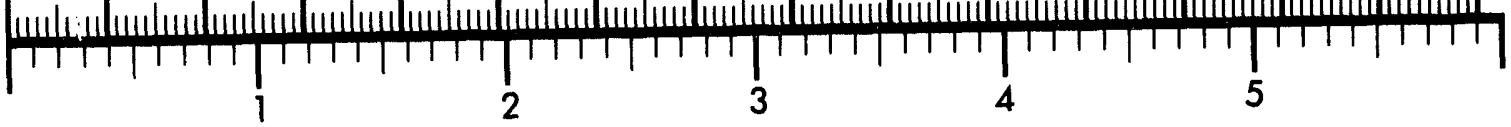
Inches
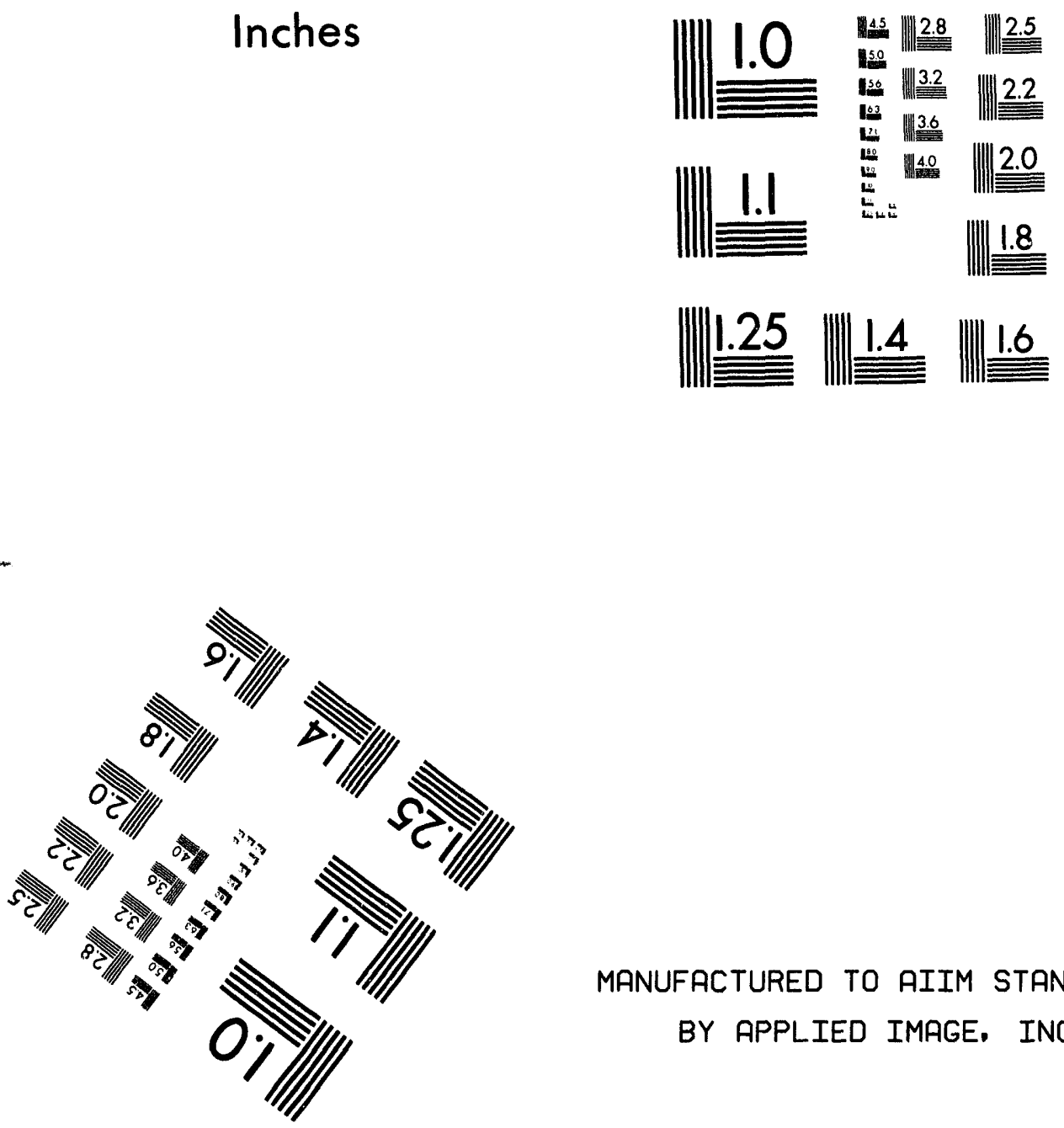

MANUFACTURED TO AIIM STANDARDS

BY APPLIED IMAGE, INC.

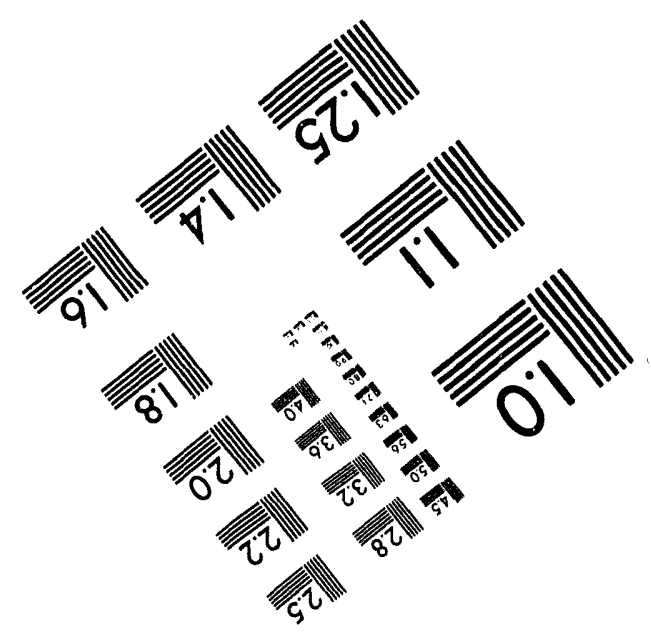



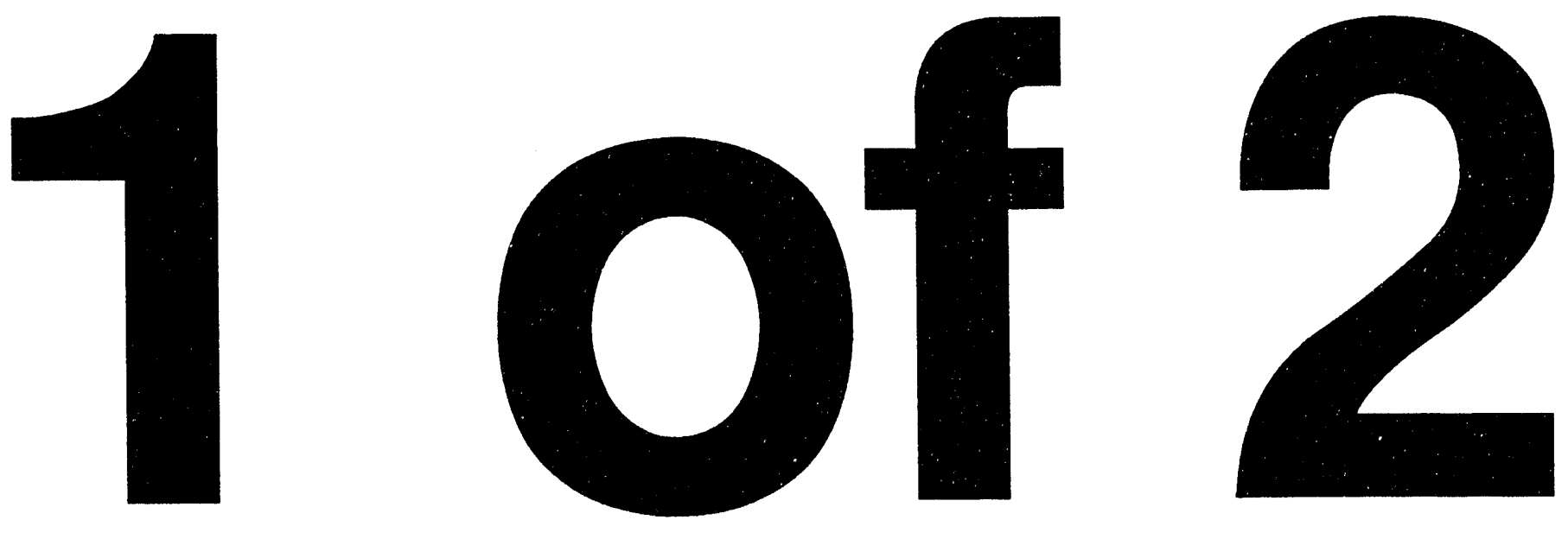
DOE/RL-94-28

Revision 0

\section{State Waste Discharge Permit Application 400 Area Septic System}

Date Published

June 1994

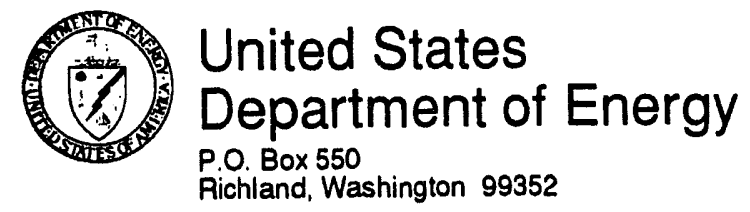

Approved for Public Release

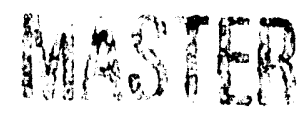


TRADEMARK DISCLAIMER

Reference herein to any specific commercial product, process, or service by trade name, trademark, manufacturer, or otherwise, does not necessarily constitute or imply its endorsement, recommendation, or favoring by the United States Government or any agency thereof or its contractors or subcontractors.

This report has been reproduced from the best available copy. Available in paper copy and microfiche.

Available to the U.S. Department of Energy

and its contractors from

Office of Scientific and Technical Information

P.O. Box 62

Oak Ridge, TN 37831

(615) 576.8401

Available to the public from the U.S. Department of Commerce National Technical Information Service

5285 Port Royal Road

Springfield, VA 22161

(703) $487-4650$

Printed in the United States of Amorica

DISCLM-5.CHP (8.91) 


\section{Department of Energy}

Richland Operations Office P.O. Box 550

Richland, Washington 99352 JUN 23

94-RPS-236

Mr. David C. Nylander

Nuclear Waste Program

State of Washington

Department of Ecology

P.0. Box 1386, MSIN 91-05

Richland, Washington 99352-0539

Dear Mr. Nylander:

STATE WASTE DISCHARGE PERMIT APPLICATIONS FOR THE TABLE 4 MISCELLANEOUS STREAMS

Transmitted herein are the State Waste Discharge Permit (SWDP) Applications for the "Miscellaneous Streams." The Miscellaneous Streams are identified on Table 4 of Ecology Consent Order DE $91 N M-177$ (216 Consent Order). The permit applications include the following:

- State Waste Discharge Permit Application - 100-N Sewage Lagoon (DOE/RL-94-22)

- State Waste Discharge Permit Application - 183-N Backwash Discharge Pond (DOE/RL-94-23)

- State Waste Discharge Permit Application - 200-E Chemical Drain Field (DOE/RL-94-24)

- State Waste Discharge Permit Application - 200-E Powerhouse Ash Pit (DOE/RL-94-25)

- State Waste Discharge Permit Application - 200-W Powerhouse Ash Pit (DOE/RL-94-26)

- State Waste Discharge Permit Application - 400 Area Septic System (DOE/RL-94-28).

Section 6, Table 4 of the 216 Consent Order identifies eleven miscellaneous streams which require the submittal of Washington Administrative Code (WAC) 173-216 SW'P Applications by June 30, 1994. Of the eleven streams identified, the five following streams do not require permitting under WAC 173-216:

- 300 Area Powerhouse Ash Waste Water (will be permitted under a National Pollutant Discharge Elimination System [NPDES] permit)

- 300 Area Filter Backwash streams (will be permitted under a NPDES permit) 
- 234-5Z Ventilation Steam Condensate/Dry Air Compressor Cooling Water (will be rerouted to and permitted under the 200 Areas Treated Effluent Disposal Facility)

- 209-E Building Steam Condensate (has been eliminated)

- 300 Area Sanitary Sewer (will be rerouted to the City of Richland Publicly Owned Treatment Works before June 1995).

The enclosed WAC 173-216 permit applications were prepared for the remaining six streams, and thus fulfill the requirements of the 216 Consent Order.

State Environmental Policy Act (SEPA) environmental checklists were not prepared for the "Miscellaneous Streams" 1isted on Table 4 of the 216 Consent Order. The SEPA regulations [WAC 197-11-855(1)] exempt the existing streams from the SEPA process.

Should you have any questions or require any additional information regarding these permit applications, please contact Mr. J. E. Rasmussen on (509) 376-2247.

EAP:JET

$$
\text { Sincerely, }
$$

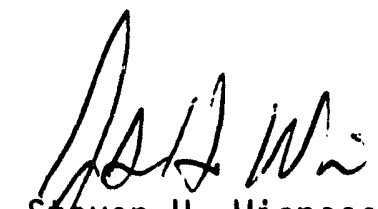

Steven $H$. Wisness, Acting Program Manager Office of Environmental Assurance,

Enclosures

cc $w / 0$ encl:

Administrative Records

B. P. Atencio, WHC

J. J. Luke, WHC

M. A. Selby, Ecology

J. E. Turnbaugh, WHC 
DOE/RL-94-28, Rev. 0

06/94

400 Area Septic System

- 209-E Building Steam Condensate

- 400 Area Sanitary Waste Water

- 200-W Powerhouse Ash Waste Water

- 200-E Powerhouse Ash Waste Water

- 300 Area Powerhouse Ash Waste Water

- 100-N Sanitary Sewer System

- 300 Area Filter Backwash

- 300 Area Sanitary Sewer System

- 234-5Z Steam Condensate/Dry Air Compressor Cooling

- 272-E, 2703-E Buildings Waste Water

- 183-N Filter Backwash Waste Water.

This document constitutes the State Waste Discharge Permit application for the 400 Area Septic System. The influent to the system is domestic waste water. Although the 400 Area Septic System is not a Public Owned Treatment Works, the Public Owned Treatment Works application is more applicable than the application for industrial waste water. Therefore, the State Waste Discharge Permit application for Public Owned Treatment Works Discharges to Land was used.

The 400 Area Sanitary Waste Water is generated from standard sanitary processes and discharged to the 400 Area Septic System. The 400 Area Sanitary Waste Water is presently being managed through the use of gravity collection lines, a septic tank, and a 
DOE/RL-94-28, Rev. 0

$06 / 94$

400 Area Septic System

1 surface disposal pond. There are approximately 700 employees in the 400 Area who use

2 the domestic waste water system.

A number of options for modifying the sewer system have been evaluated in order 5 to eliminate the current surface infiltration pond. In 1991 a tie line that would route

7 was completed. Department of Energy, Richland Operations Office has been negotiating

8 a contract with the Washington Public Power Supply System; however, to date, no

9 agreement has been reached.

An engineering study of the various systems to determine the best alternative for the 400 Area Sanitary Sewage, in case the Department of Energy, Richland Operations Office and the Washington Public Power Supply System fail to reach an agreement, was performed in 1993. The recommendation of the Engineering Study was to pursue a fully lined surface evaporation pond. The Department of Energy, Richland Operations Office and Westinghouse Hanford Company are currently evaluating the construction of a fully lined evaporative lagoon treatment system. 
DOE/RL-94-28, Rev. 0 $06 / 94$

400 Area Septic System

\section{CONTENTS}

FOREWORD $\ldots \ldots \ldots \ldots \ldots \ldots \ldots \ldots \ldots \ldots \ldots \ldots \ldots \ldots \ldots \ldots \ldots \ldots \ldots \ldots$ ii

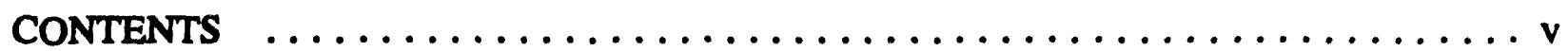

GLOSSARY $\ldots \ldots \ldots \ldots \ldots \ldots \ldots \ldots \ldots \ldots \ldots \ldots \ldots \ldots \ldots \ldots \ldots$ vii

METRIC CONVERSION CHART $\ldots \ldots \ldots \ldots \ldots \ldots \ldots \ldots \ldots$ viii

1.0 PERMIT APPLICATION $\ldots \ldots \ldots \ldots \ldots \ldots \ldots \ldots \ldots \ldots$ Application-1

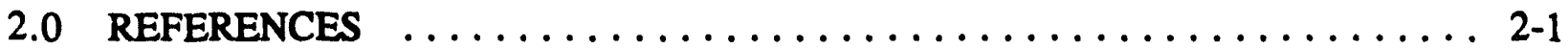

APPENDICES:

A GENERAL INFORMATION $\ldots \ldots \ldots \ldots \ldots \ldots \ldots \ldots \ldots \ldots \ldots$ A-1

B TREATMENT PLANT INFORMATION $\ldots \ldots \ldots \ldots \ldots \ldots \ldots \ldots \ldots$ B-1

C WASTE WATER INFORMATION $\ldots \ldots \ldots \ldots \ldots \ldots \ldots \ldots \ldots \ldots$ C-1

D SLUDGE MANAGEMENT AND DISPOSAL $\ldots \ldots \ldots \ldots \ldots \ldots \ldots \ldots$ D-1

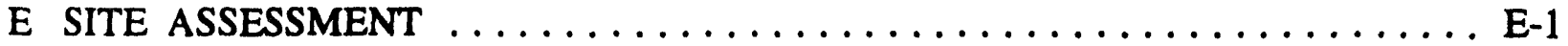


DOE/RL-94-28, Rev. 0

06/94

400 Area Septic System

1

2

3

4

5

6

This page intentionally left blank. 
DOE/RL-94-28, Rev. 0 06/94

400 Area Septic System

\section{GLOSSARY}

BMP

BOD

CFR

COD

DOE

DOE-RL

Ecology

EPA

gpd

GWQC

MGD

$\mathrm{mg} / \mathrm{L}$

PNL

POTW

PSPL

RCRA

RCW

SWDP

TKN

ug/L

USGS

WAC

WHC

WPPSS best management practice

biological oxygen demand

Code of Federal Regulations

chemical oxygen demand

U.S. Department of Energy

U.S. Department of Energy, Richland Operations Office

Washington State Department of Ecology

U.S. Environmental Protection Agency

gallons per day

Ground Water Quality Criteria

million gallons per day

milligrams per liter

Pacific Northwest Laboratory

Public Owned Treatment Works

Puget Sound Power and Light Company

Resource Conservation and Recovery Act

Revised Code of Washington

State Waste Discharge Permit

total Kjedldahl nitrogen

micrograms per liter

United States Geological Survey

Washington Administrative Code

Westinghouse Hanford Company

Washington Public Power Supply System 
DOE/RL-94-28, Rev. 0

06/94

400 Area Septic System

\section{METRIC CONVERSION CHART}

INTO METRIC UNITS

OUT OF METRIC UNITS

\begin{tabular}{|c|c|c|c|c|c|}
\hline If you know & Multiply by & To get & If you know & Multiply by & To get \\
\hline \multicolumn{3}{|c|}{ l length } & \multicolumn{3}{|c|}{ Length } \\
\hline inches & 2.54 & centimeters & centimoters & 0.393 & inches \\
\hline feet & 0.3048 & meters & meters & 3.2808 & feet \\
\hline yards & 0.914 & meters & moters & 1.09 & yards \\
\hline miles & 1.609 & kilometers & kilometers & 0.62 & miles \\
\hline \multicolumn{3}{|c|}{ Area } & \multicolumn{3}{|c|}{ Area } \\
\hline square feet & 0.092 & square meters & square meters & 10.7639 & square feet \\
\hline square yards & 0.836 & square meters & square meters & 1.20 & square yards \\
\hline square miles & 2.59 & $\begin{array}{l}\text { square } \\
\text { kilometers }\end{array}$ & $\begin{array}{l}\text { square } \\
\text { kilomoters }\end{array}$ & 0.39 & square miles \\
\hline acres & 0.404 & hectares & hectares & 2.471 & acres \\
\hline \multicolumn{3}{|c|}{ Mass (weight) } & \multicolumn{3}{|c|}{ Mass (weight) } \\
\hline ounces & 28.35 & grams & grams & 0.0352 & ounces \\
\hline pounds & 0.453 & kilograms & kilograms & 2.2046 & pounds \\
\hline short ton & 0.907 & metric ton & metric ton & 1.10 & short ton \\
\hline \multicolumn{3}{|c|}{ Volume } & \multicolumn{3}{|c|}{ Volume } \\
\hline fluid ounces & 29.57 & milliliters & milliliters & 0.03 & fluid ounces \\
\hline quarts & 0.95 & liters & liters & 1.057 & quarts \\
\hline gallons & 3.79 & liters & liters & 0.26 & gallons \\
\hline cubic feet & 0.03 & cubic meters & cubic meters & 35.3147 & cubic feet \\
\hline cubic yards & 0.76 & cubic meters & cubic meters & 1.308 & cubic yards \\
\hline \multicolumn{3}{|c|}{ Temperature } & \multicolumn{3}{|c|}{ Temperature } \\
\hline Fahrenheit & $\begin{array}{l}\text { subtract } 32 \\
\text { then wultiply } \\
\text { by } 5 / 9 \text { ths }\end{array}$ & Celsius & Celsius & $\begin{array}{l}\text { multiply by } \\
9 / 5 \text { ths, then } \\
\text { add } 32\end{array}$ & Fahrenheit \\
\hline
\end{tabular}

Source: Lindeburg 1990. 
DOE/RL-94-28, Rev. 0

400 Area Septic System

\subsection{PERMIT APPLICATION}

This section presents the State Waste Discharge Permit (SWDP) application for the $\mathbf{4 0 0}$ Area Septic System. The $\mathbf{4 0 0}$ Area Sanitary Waste Water is generated from standard sanitary processes and is discharged to the 400 Area Septic System. The 400 Area Sanitary Waste Water is presently being managed through the use of gravity collection lines, a septic tank, and a surface disposal pond. There are approximately 700 employees in the 400 Area who use the domestic waste water system.

\subsection{ORGANIZATION}

The Washington Administrative Code (WAC) 173-216 SWDP application form for the 400 Area Septic System is presented in this section. Information required by the SWDP application form is provided on the form when adequate space is available. Otherwise, information is provided in the appendices as noted on the completed form. The appendices follow precisely the format of the SWDP application and are designed to supplement the permit application form. Appendix A contains site location maps referenced in Section A of the permit application form. Appendices B through E correspond to Sections B through E in the permit application form. Within each appendix, those questions which require additional space have been restated and the answer directly follows the question. The questions in the appendices are worded precisely as they are in the application form, and are highlighted in bold capital letters which are underlined.

\subsection{STATE WASTE DISCHARGE PERMIT APPLICATION FORM}

The following pages contain the SWDP application for the 400 Area Septic System. 
DOE/RL-94-28, Rev. 0

06/94

400 Area Septic System

This page intentionally left blank.

Application-2 


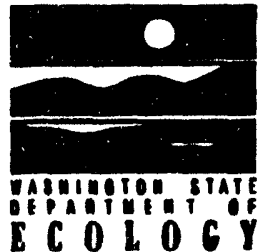

\section{STATE WASTE DISCHARGE PERMIT APPLICATION FOR POTW DISCHARGES TO LAND}

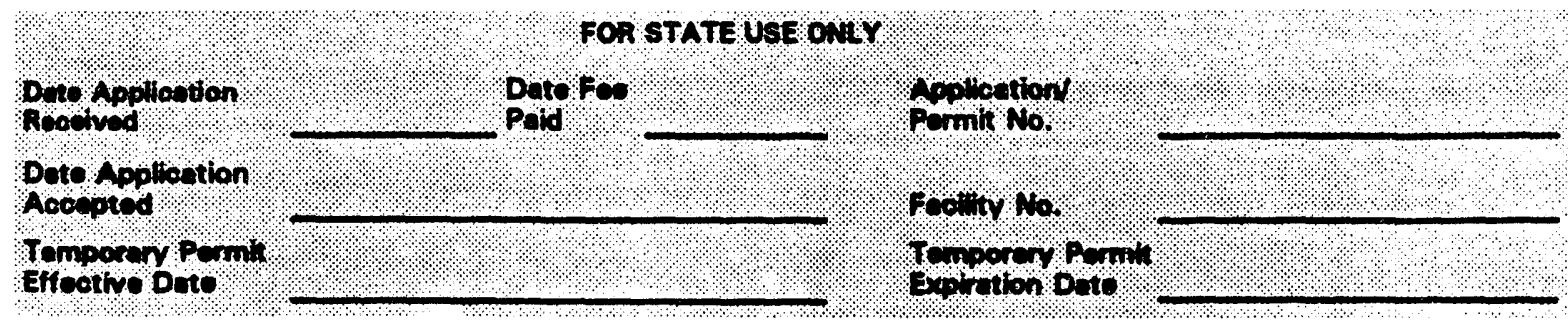

This application is for a waste discharge permit as required in accordance with provisions of Chapter 90.48 RCW and Chapter 173-216 WAC. Additional information may be required. Information previously submitted and applicable to this application should be referenced in the appropriate section.

\section{SECTION A. GENERAL INFORMATION}

1. Applicant Name: $\quad$ U.S Department of Energy. Richland Operations Office

2. Facility Name: (If different from applicant) 400 Area Septic System

3. Unified Business Identification Number (UBI \#): 21-0565159 (DOE tax exempt number)

4. Mailing Address: P.O. Box 550

Streot
Richland, WA
City/Stote
400 Area - Hanford Site
Streot
See Maps in Appendix A.
City/Stote
99352

5. Facility Address: 400 Area - Hanford Site

6. Person to contact who is familiar with the information contained in this application: J.E. Rasmussen US DOE, Branch Chief, Regulatory Permits Name Titlo 509-376-2247

7. Check One: $\square$ Permit Renewal Existing Unpermitted Discharge Proposed Discharge Anticipated date of discharge:

I certify under penalty of law that this document and all antachments were prepared under my direction or supervision in accordance with a system designed to assure that qualified personnel properly gather and evaluate the information submitted. Based on my inquiny of the person or persons who manage the system, or those persons directly responsible for gathering the information, the information submitted is, to the best of my knowledge and belief, true, accurate, and complete. I am aware that there are significant penalties for submitting false information, including the possibilipy of a fine and/or imprisonn.ent for knowing violations.

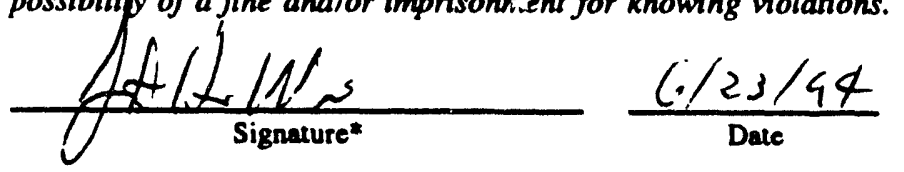

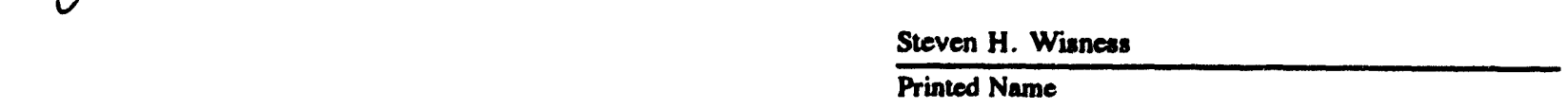

*Applications must be signed by either a principal executive officer or a ranking elected official.
Acting Program Manager, Office of Environmental Assurance, Permits and Policy Title

Page 1 of 6 


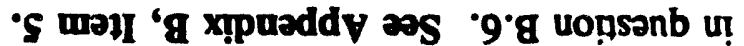

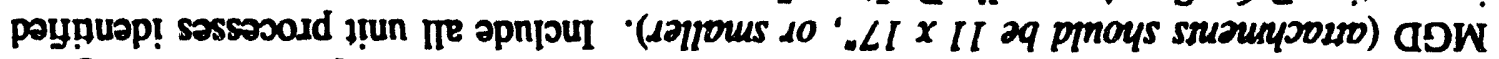

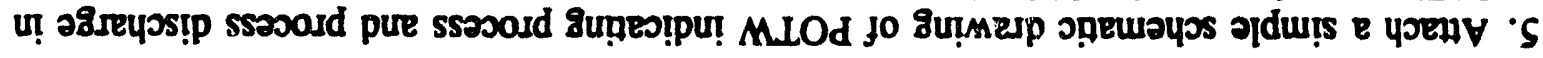

\begin{tabular}{c}
\hline $00 L$ \\
\hline$* 9661$ \\
\hline$\varepsilon 861$ \\
\hline $8 L 61$ \\
\hline$* \varepsilon 0^{\circ}+9$ \\
\hline$* 11^{\circ} 9 t$ \\
$* \varepsilon 20^{\circ} 0$
\end{tabular}

$$
\begin{aligned}
& \text { :uop̣eindod usised } \\
& \text { :(resh suotsinsoy pourueld if }
\end{aligned}
$$

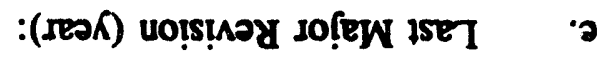

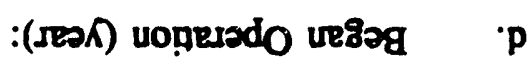

$$
\begin{aligned}
& \text { :(Kep/squ peon SS Ju⿰nyuI } 0 \\
& \text { :(Kep/sqD peon GOG juonjuI }
\end{aligned}
$$

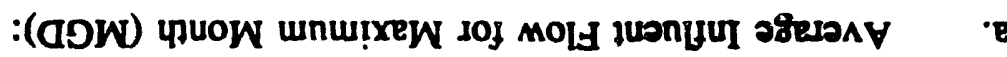

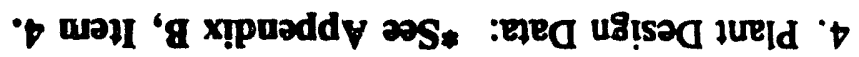
- podoponop UอSQ OAEY STEnuEU

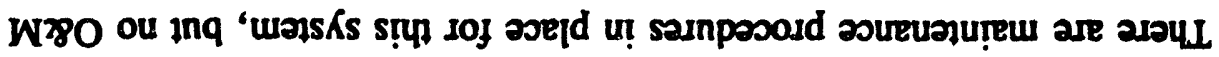

$\begin{array}{ll}\square & \square \\ \square & \square \\ \text { ON }_{\text {SOX }}\end{array}$

MLOd IE Kdoj

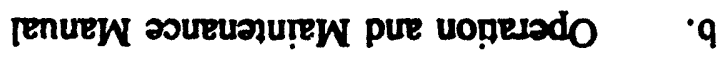

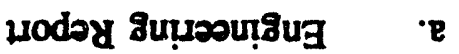
$\operatorname{adK} \mathbf{I}$

:s[enuew uopiedodo pure usissad jureld ' $\varepsilon$

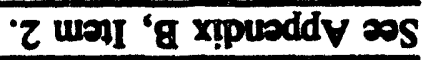

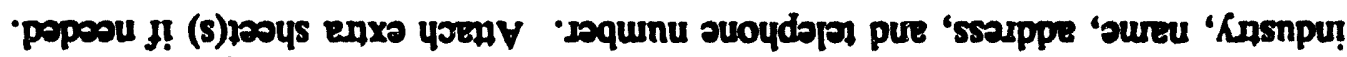

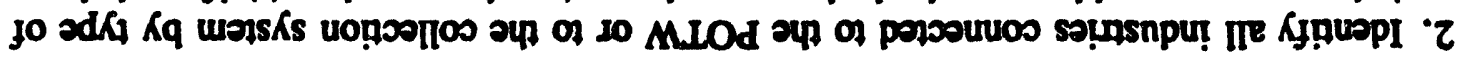

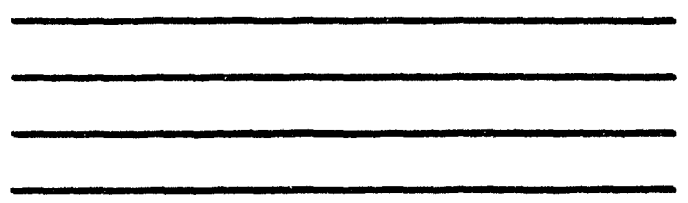

possos uop̣etndod

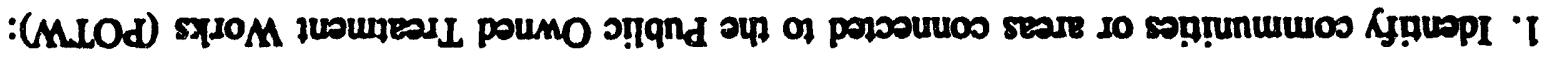


6. Check appropriate unit process.

\begin{tabular}{|c|c|c|c|c|}
\hline Treatment & \multicolumn{3}{|c|}{ Unit Process } & Check \\
\hline \multirow{6}{*}{ Preliminary Treatment } & \multicolumn{3}{|c|}{ Manually Operated Bar Screens } & \\
\hline & \multicolumn{3}{|c|}{ Mechanically Operated Bar Screens } & \\
\hline & \multicolumn{3}{|l|}{ Grit Removal } & \\
\hline & \multicolumn{3}{|l|}{ Pre-Aeration } & \\
\hline & \multicolumn{3}{|l|}{ Comminutors/Grinders } & \\
\hline & \multicolumn{3}{|l|}{ Other (specify) } & \\
\hline \multirow{2}{*}{ Primary Treatment } & \multicolumn{3}{|c|}{ Primary Sedimentation Tank/Clarifiers } & \\
\hline & \multicolumn{3}{|c|}{ Other (specify) - 50,000 Gallon Septic Tank } & $\checkmark$ \\
\hline \multirow{6}{*}{ Secondary Treatment } & \multicolumn{3}{|l|}{ Oxidation Ditch } & \\
\hline & \multicolumn{3}{|l|}{ Aerated Lagoon } & \\
\hline & \multicolumn{3}{|l|}{ Non-aerated Lagoon } & \\
\hline & \multicolumn{3}{|l|}{ Secondary Clarifiers } & \\
\hline & \multicolumn{3}{|l|}{ Polishing Ponds } & \\
\hline & \multicolumn{3}{|l|}{ Other (specify) } & \\
\hline \multirow{5}{*}{ Additional Treatment } & \multicolumn{3}{|l|}{ Coagulation } & \\
\hline & \multicolumn{3}{|l|}{ Filtration } & \\
\hline & \multicolumn{3}{|l|}{ Storage (Lined Lagoon) } & \\
\hline & \multicolumn{3}{|l|}{ Storage (Unlined Lagoon) } & \\
\hline & \multicolumn{3}{|l|}{ Other (specify) } & \\
\hline \multirow{2}{*}{ Disinfection } & \multicolumn{3}{|l|}{ Chlorination } & \\
\hline & \multicolumn{3}{|l|}{ Other (specify) } & \\
\hline \multirow{5}{*}{ Land Application } & Method & Check & Mothod & Check \\
\hline & Drainfield & & Flood Irrigation & \\
\hline & Rapid Infiltration & & $\begin{array}{l}\text { Ridge and Furrow } \\
\text { Irrigation }\end{array}$ & \\
\hline & Constructed Wetlands & & Subsurface Irrigation & \\
\hline & Sprinkler Irrigation & & $\begin{array}{l}\text { Other - Infiltration } \\
\text { Pond }\end{array}$ & $\checkmark$ \\
\hline
\end{tabular}




\section{SECTION C. WASTEWATER INFORMATION}

1. Provide measurements for treated wastewater prior to land application for the parameters listed below, unless waived by the permitting authority. All analytical methods used to meet these requirements shall, unless approved otherwise in writing by Ecology, conform to the Guidelines Extablishine Test Procedures for the Analysis of Pollutants Contained in 40 CER Prit 136.

\begin{tabular}{|c|c|c|c|}
\hline Paramoter & $\begin{array}{l}\text { Concentrations } \\
\text { Measured }\end{array}$ & $\begin{array}{l}\text { Analytical } \\
\text { Mothod }\end{array}$ & $\begin{array}{l}\text { Detection } \\
\text { Limit }\end{array}$ \\
\hline pH & \multicolumn{3}{|c|}{ See Appendix C, Item 1.} \\
\hline \multicolumn{4}{|l|}{ Conductivity } \\
\hline \multicolumn{4}{|c|}{ Total Dissolved Solids } \\
\hline \multicolumn{4}{|c|}{ Total Suspended Solids } \\
\hline \multicolumn{4}{|l|}{ BOD (5 day) } \\
\hline \multicolumn{4}{|c|}{ Total Fissidual Chlorine } \\
\hline \multicolumn{4}{|l|}{ Ammonia-N } \\
\hline \multicolumn{4}{|l|}{ TKN-N } \\
\hline \multicolumn{4}{|l|}{ Nitrate-N } \\
\hline \multicolumn{4}{|l|}{ Ortho-phosphate-P } \\
\hline \multicolumn{4}{|l|}{ Total-phosphate-P } \\
\hline \multicolumn{4}{|l|}{ Total Oil \& Grease } \\
\hline \multicolumn{4}{|l|}{ Calcium } \\
\hline \multicolumn{4}{|l|}{ Magnesium } \\
\hline \multicolumn{4}{|l|}{ Sodium } \\
\hline \multicolumn{4}{|l|}{ Potassium } \\
\hline \multicolumn{4}{|l|}{ Chloride } \\
\hline \multicolumn{4}{|l|}{ Sulfate } \\
\hline \multicolumn{4}{|l|}{ Fluoride } \\
\hline \multicolumn{4}{|l|}{ Cadmium (total) } \\
\hline \multicolumn{4}{|l|}{ Chromium (total) } \\
\hline \multicolumn{4}{|l|}{ Lead (total) } \\
\hline \multicolumn{4}{|l|}{ Mercury } \\
\hline \multicolumn{4}{|l|}{ Selenium (total) } \\
\hline \multicolumn{4}{|l|}{ Silver (total) } \\
\hline \multicolumn{4}{|l|}{ Copper (total) } \\
\hline \multicolumn{4}{|l|}{ Iron (total) } \\
\hline \multicolumn{4}{|l|}{ Manganese (total) } \\
\hline \multicolumn{4}{|l|}{ Zine (total) } \\
\hline \multicolumn{4}{|l|}{ Barium (total) } \\
\hline Fecal Coliform & & & . \\
\hline Total Coliform & & & \\
\hline
\end{tabular}


2. Has the effluent been analyzed for any other parameters than those identified in question C.1? If so, when? Attach results. (Note: Ecology may require additional testing.) See Appendix C, Item 2.

\section{SECTION D. SLUDGE MANAGEMENT AND DISPOSAL}

\section{Sludge Management Plan $\square$ Yes $x$ No}

Plan approved by: See Appendix D, Item 1.

Local Health District

Department of Ecology

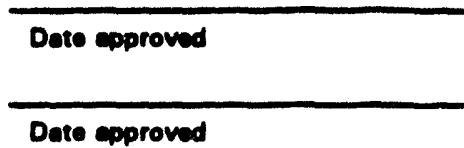

2. Describe sludge generation, stabilization, utilization, and disposal. Attach extra sheets as necessary.

The septic tank accumulates settleable solids. The solids from the septic tank are scheduled to be pumped every three to five years as needed per the septic system maintenance procedure. The solids are disposed of in the 100-N Sanitary Sewer.

\section{SECTION E. SITE ASSESSMENT}

1. Give the legal description of the land treatment site(s). Give the acreage of each land treatment site(s). Attach a copy of the contract(s) authorizing use of land for treatment.

See Appendix E, Item 1.

2. List all environmental control permit or approvals needed for this project; for example, septic tank permits, sludge application permits, or air emissions permits.

See Appendix E, Item 2. 
3. Attach a United States Geological Survey (USGS) topographic map. Show the following on this map:

a. Location and name of internal and adjacent streets

b. Surface water drainage systems within $1 / 4$ mile of the site

c. All wells within 1 mile of the site

d. Chemical and product handling and storage facilities

c. Infiltration sources, such as drainfields and lagoons within $t / /$ mile of the site

f. Wastewater discharge points including bypasses

g. Other activities and land uses within $k$ mile of the site

See Appendix E, Item 3.

4. Attach well loss and well I.D.\# when available for all wells within 500 feet and any available water quality data.

See Appendix E, Item 4.

5. Describe soils on the site using information from local soil survey reports.

(Submit on separate sheet.)

See Appendix E, Item 5.

6. Describe the local geology and hydrogeology within one mile of the site.

(Submit on separate sheet.)

See Appendix E, Item 6.

7. List the names and addresses of contractors of consultants who provided information and cite sources of information by title and author.

See Appendix E, Item 7. 
DOE/RL-94-28, Rev. 0

06/94

400 Area Septic System

\subsection{REFERENCES}

Baker, V. R., B. N. Bjornstad, A. J. Busacca, K. R. Fecht, E. P. Kiver, U. L. Moddy, J. G. Rigby, D. F. Stradling, and A. M. Tallman, 1991, "Quaternary Geology of the Columbia Plateau," Quaternary Nonglacial Geology; Conterminous U.S., R. B. Morrison, Editor, Geology of North America, Geological Society of America, Vol. K-2, Boulder, Colorado.

Bovay, 1993, 400 Area Sanitary Waste Engineering Study, WHC-SD-WM-ER-341, Rev. 0, Bovay Northwest Inc., Richland, Washington.

DOE, 1988, Site Characterization Plan, Reference Repository Location, Hanford Site, Washington, Consultation Draft, DOE-RW-0164, U.S. Department of Energy, Office of Civilian Radioactive Waste Management, Washington, D.C.

DOE-RL, 1993, Phase I and II Feasibility Study Report for the 300-FF-5 Operable Unit, DOE-RL-93-22, U.S. Department of Energy, Richland Operations Office, Richland, Washington.

Ecology, U.S. EPA, U.S. DOE, 1994, Hanford Federal Facility Agreement and Consent Order, 2 volumes as amended, Washington State Department of Ecology, U.S. Environmental Protection Agency, and U.S. Department of Energy, Olympia, Washington.

EPA, 1979, Methods for the Chemical Analysis of Water and Wastes, EPA-600/4-79-020, U.S. Environmental Protection Agency, Washington D.C.

EPA, 1980, Design Manual, Onsite Wastewater Treatment and Disposal System, EPA 625/1-80-012, U.S. Environmental Protection Agency, Washington D.C.

EPA, 1992, Test Methods for Evaluating Solid Waste, Physical/Chemical Methods, SW-846, Latest Edition, U.S. Environmental Protection Agency, Washington DC.

Fecht, K. R., S. P. Reidel, and A. M. Tallman, 1987, Paleodrainage of the Columbia River System on the Columbia Plateau of Washington: A Summary, RHO-BW-SA-318P, Rockwell Hanford Operations, Richland, Washington.

Gephart, R. E., R. C. Arnett, R. G. Baca, L. S. Leonhart, and F. A. Spane Jr., 1979, Hydrologic Studies Within the Columbia Plateau, Washington: An Integration of Current Knowledge, RHO-BWI-ST-5, Rockwell Hanford Operations, Richland, Washington. 
Hajek, B. F., 1966, Soil Survey: Hanford Project in Benton County, Washington, BNWL-243, Pacific Northwest Laboratory, Richland, Washington.

HEDL, 1975, Final Soil Investigation Report for the Fast Flux Test Facility Richland, Washington for the United States Atomic Energy Commission, HEDL-BC-6041, Hanford Engineering Development Laboratory, Westinghouse Hanford Company, Richland, Washington (from Bechtel, 1971, Final Soil Investigation Report for the Fast Flux Test Facility Richland, Washington, for the United States Atomic Energy Commission, TID-25934, Bechtel Corporation, San Francisco, CA).

John A. Blume \& Associates, 1970, Siesmic and Geologic Siting Evaluation Fast Flux Test Facility Near Richland, Washington, JABE-WADCO-01, WADCO, Richland, Washington.

John A. Blume \& Associates, 1971, Subsurface Geologic Investigations for the FFTF Project in Pasco Basin, JABE-WADCO-07, WADCO, Richland, Washington.

Lindeburg, M. R. PE, Engineering Unit Conversions, Second Ed, 1990, Professional Publications, Inc., Belmont, California.

Metcalf and Eddy, 1991, Wastewater Engineering: Treatment, Disposal, and Reuse, Third Edition. Revised by George Tchobanoglous and Franklin L. Burton, McGraw-Hill Publishing Company, New York, New York.

PNL, 1989, Hydrogeology of the 200 Areas Low-Level Burial Grounds An Interim Report, PNL-6820, Pacific Northwest Laboratory, Richland, Washington.

PSPL, 1982, Skagit/Hanford Nuclear Project, Preliminary Safety Analysis Report, Vol. 4, App. 20, Amendment 23, Puget Sound Power and Light Company, Bellevue, Washington.

Reidel, S. P. and K. R. Fecht, 1981, "Wanapum and Saddle Mountains Basalt in the Cold Creek Syncline Area," Subsurface Geology of the Cold Creek Syncline, RHO-BWI-ST-14, Rockwell Hanford Operations, Richland, Washington.

Smith, G. A., B. N. Bjornstad, and K. R. Fecht, 1989, "Neogene Terrestrial Sedimentation on and Adjacent to the Columbia Plateau; Washington, Oregon, and Idaho," Volcanism and Tectonism in the Columbia River Hlood-Basalt Province, Special Paper 239, S. P. Reidel, and P. R. Hooper, editors, Geological Society of America, Boulder, Colorado. 
DOE/RL-94-28, Rev. 0

$06 / 94$

400 Area Septic System

Tallman, A. M., K. R. Fect, M. C. Marratt, and G. V. Last, 1979, Geology of the Separations Areas, Hanford Site, South-Central, Washington, RHO-ST-23, Rockwell Hanford Operations, Richland, Washington.

USPHS, 1988, Septic System Design Manual, United States Public Health Service, Washington D.C.

WHC, 1975, Final Geology Report for the Fast Flux Test Facility Richland, Washington for the United States Atomic Energy Commission, BR-5853-C-005, Hanford Engineering Development Laboratory, Richland, Washington.

WHC, 1991a, Geology and Hydrology of the 300 Area and Vicinity, Hanford Site, SouthCentral Washington, WHC-EP-0500, Westinghouse Hanford Company, Richland, Washington.

WHC, 1991b, Geology and Hydrology of the Hanford Site: A Standardized Text for Use in Westinghouse Hanford Company Documents and Reports, WHC-SD-ER-TI-003, Westinghouse Hanford Company, Richland, Washington.

WHC, 1991c, Revised Stratigraphy for the Ringold Formation, Hanford Site, South Central Washington, WHC-SD-EN-EE-004, Westinghouse Hanford Company, Richland, Washington.

WHC, 1991d, Geologic Setting of the 200 West Area: An Update, WHC-SD-EN-TI-008, Rev. 0, Westinghouse Hanford Company, Richland, Washington.

WHC, 1992a, Summary of the Geology of the 200-BP-1 Operable Unit, WHC-SD-EN-TI-037, Rev. 0, Westinghouse Hanford Company, Richland, Washington.

WHC, 1992b, Geologic Setting of the 200 East Area: An Update, WHC-SD-EN-TI-012, Rev. 0, Westinghouse Hanford Company, Richland, Washington.

WHC, 1992c, Groundwater Impact Assessment Report for the 400 Area Ponds, WHC-EP-0587, Westinghouse Hanford Company, Richland, Washington.

WHC, 1993a, Characterization Report for the Table 4 Miscellaneous Streams in Consent Order No. DE 91NM-177, WHC-SD-EN-EV-020, Rev. 0, Westinghouse Hanford Company, Richland, Washington.

WHC, 1993b, Sampling and Analysis Plan for Miscellaneous Streams, WHC-DS-WM-PLN-069, Rev. 0, Westinghouse Hanford Company, Richland, Washington. 
DOE/RL-94-28, Rev. 0

06/94

400 Area Septic Syctem

1 WHC, 1994, Groundwater Map of the Hanford Site, WHC-EP-0394-7, Westinghouse

2 Hanford Company, Richland, Washington.

3 
DOE/RL-94-28, Rev. 0

06/94

400 Area Septic System

\section{APPENDICES}

APPENDIX A GENERAL INFORMATION $\ldots \ldots \ldots \ldots \ldots \ldots \ldots \ldots$ A-:

APPENDIX B TREATMENT PLANT INFORMATION $\ldots \ldots \ldots \ldots \ldots$ B-1

APPENDIX C WASTE WATER INFORMATION $\ldots \ldots \ldots \ldots \ldots \ldots$ C-1

APPENDIX $D$ SLUDGE MANAGEMENT AND DISPOSAL $\ldots \ldots \ldots \ldots$ D-1

APPENDIX E SITE ASSESSMENT $\ldots \ldots \ldots \ldots \ldots \ldots \ldots \ldots \ldots$ E-1 
DOE/RL-94-28, Rev. 0

06/94

400 Area Septic System

1

2

3

4

5

6

This page intentionally left blank. 
DOE/RL-94-28, Rev. 0 06/94

400 Area Septic Syctem

This page intentionally left blank. 
DOE/RL-94-28, Rev. 0

06/94

400 Area Septic System

\section{CONTENTS}

\section{EIGURES}

A-1 General Hanford Site Map. ........................ A-1

A-2 Location of the 400 Area Septic System. . . . . . . . . . . . . . A-2 
DOE/RL-94-28, Rev. 0

06/94

400 Aree Septic System

This page intentionally left blank. 
DOE/RL-94-28, Rev. 0

06/94

400 Area Septic System

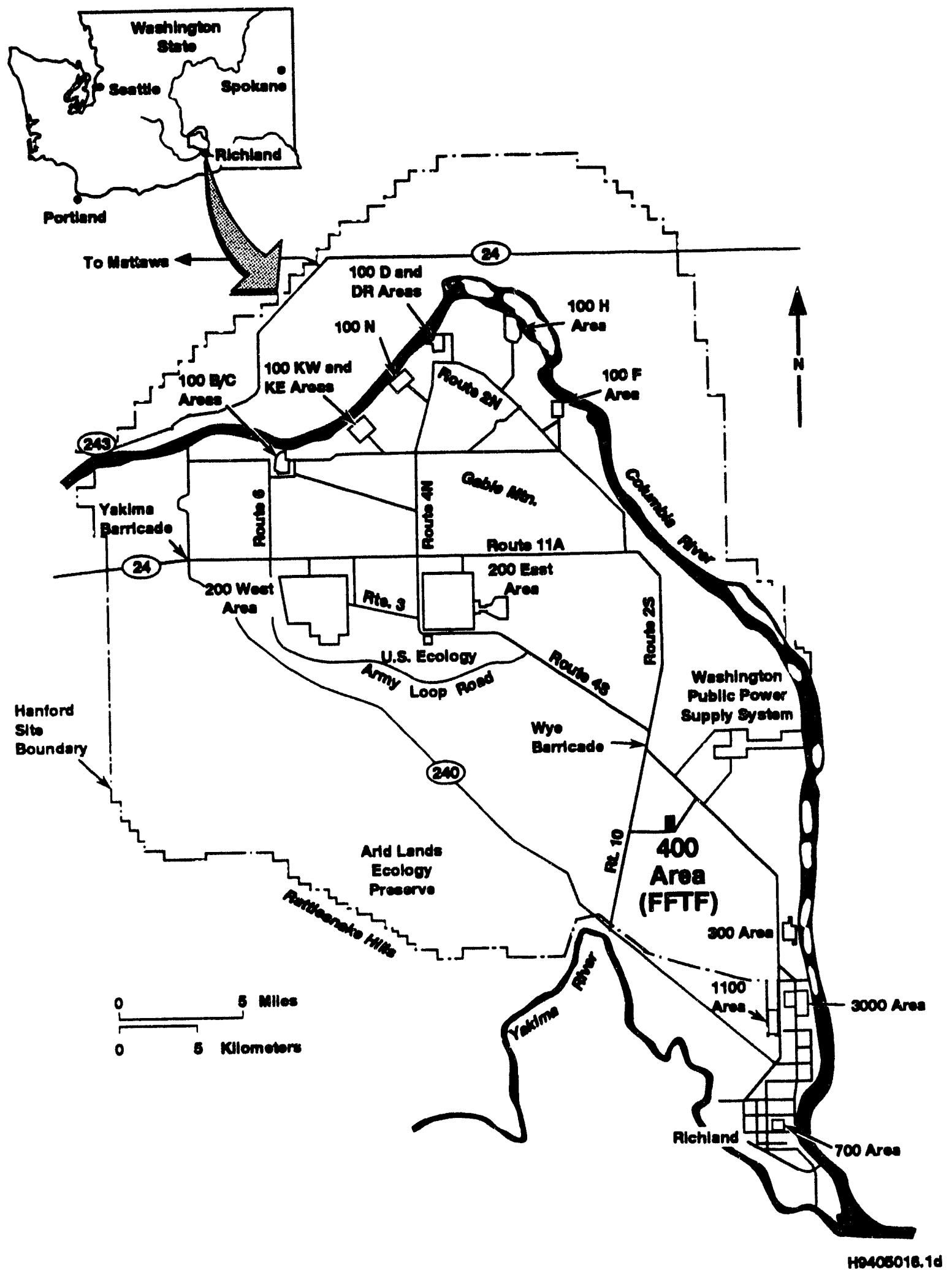

Figure A-1. General Hanford Site Map. 
DOE/RL-94-28, Rev. 0

400 Area Septic System

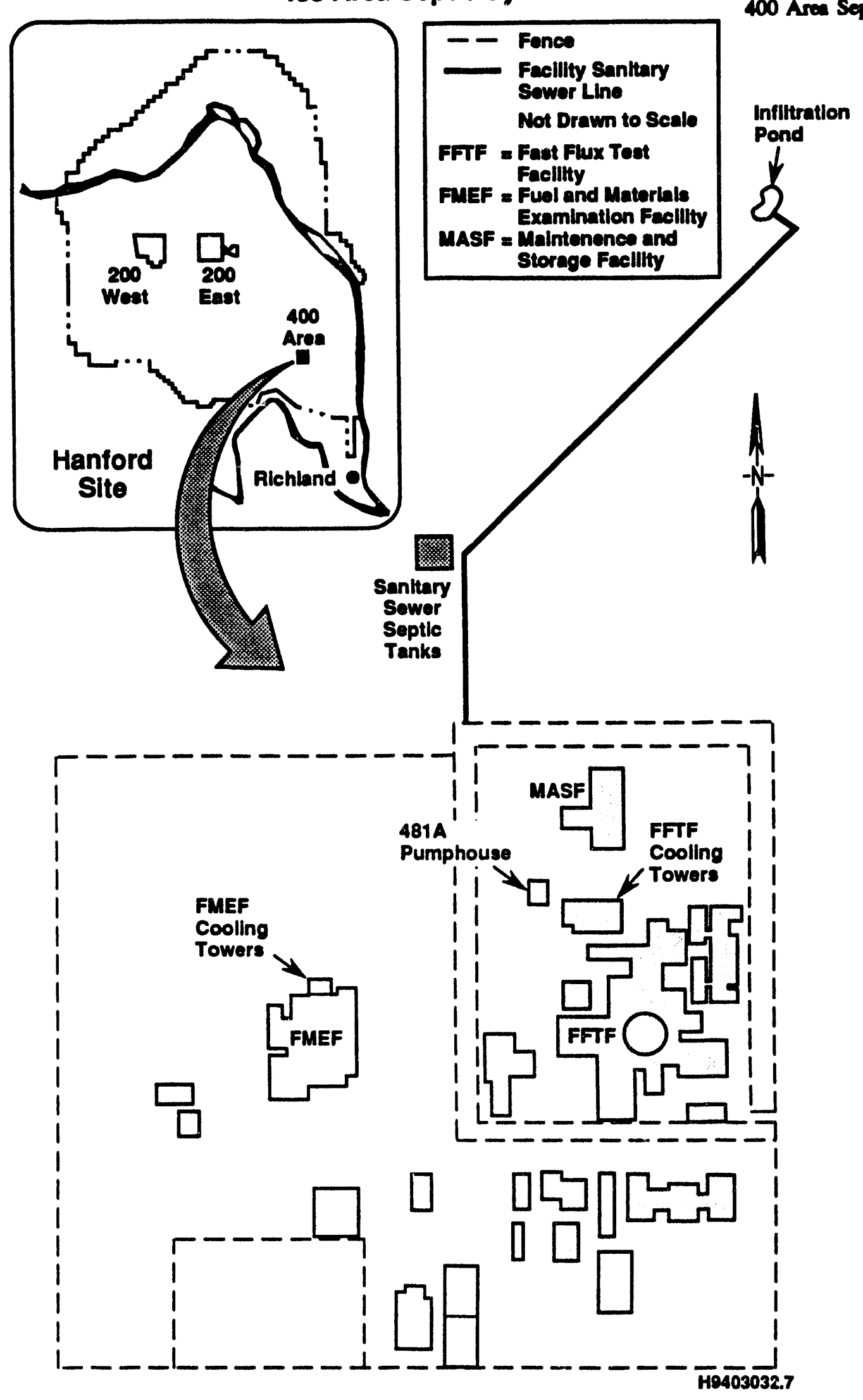

06/94

400 Area Septic System

Infiltration

Pond

FUEF = Fual and Matorlals

Wxamination Faollity

Maintenenes and

$\mathcal{3}$

Figure A-2. Location of the 400 Area Septic System. 
DOE/RL-94-28, Rev. 0 06/94

400 Ares Septic System

APPENDIX B

TREATMENT PLANT INFORMATION

App B-i 
DOE/RL-94-28, Rev. 0

06/94

400 Area Septic System

1

2

3

4

5

6

This page intentionally left blank. 
DOE/RL-94-28, Rev. 0

$06 / 94$

400 Aree Septic System

\section{CONTENTS}

SECTION B, ITEM 1

IDENTIFY COMMUNITIES OR AREAS CONNECTED TO THE

PUBLIC OWNED TREATMENT WORKS (POTW): $\ldots \ldots \ldots \ldots \ldots \ldots \ldots$ B-1

SECTION B, TTEM 2

IDENTIFY ALL INDUSTRIES CONNECTED TO THE POTW OR

TO THE COLLECTION SYSTEM BY TYPE OF INDUSTRY, NAME, ADDRESS, AND TELEPHONE NUMBER. ATTACH

EXTRA SHEET(S) IF NEEDED. $\ldots \ldots \ldots \ldots \ldots \ldots \ldots \ldots \ldots \ldots$ B-1

SECTION B, ITEM $4 a, 4 b$, and $4 c . \ldots \ldots \ldots \ldots \ldots \ldots \ldots \ldots \ldots \ldots \ldots \ldots$

SECTION B, ITEM $4 \mathrm{f}$

PLANNED REVISIONS (YEAR): $\ldots \ldots \ldots \ldots \ldots \ldots \ldots \ldots \ldots \ldots \ldots \ldots$ B-3

SECTION B, TTEM 5

ATTACH A SIMPLE SCHEMATIC DRAWING OF POTW

INDICATING PROCESS AND PROCESS DISCHARGE IN MGD

(ATTACHMENTS SHOULD BE 11"X 17", OR SMALLER) .

INCLUDE ALL UNIT PROCESSES IDENTIFIED IN QUESTION B.6. . . . . B-3

TABLE

B-1 Buildings Connected to the 400 Area Septic System ............. B-2

FIGURE

B-1 Schematic Diagram for the 400 Area Septic System $\ldots \ldots \ldots \ldots \ldots \ldots$. . 4 
DOE/RL-94-28, Rev. 0 06/94

100 Area Septic Systom

This page intentionally left blank. 
DOE/RL-94-28, Rev. 0

06/94

400 Area Soptic System

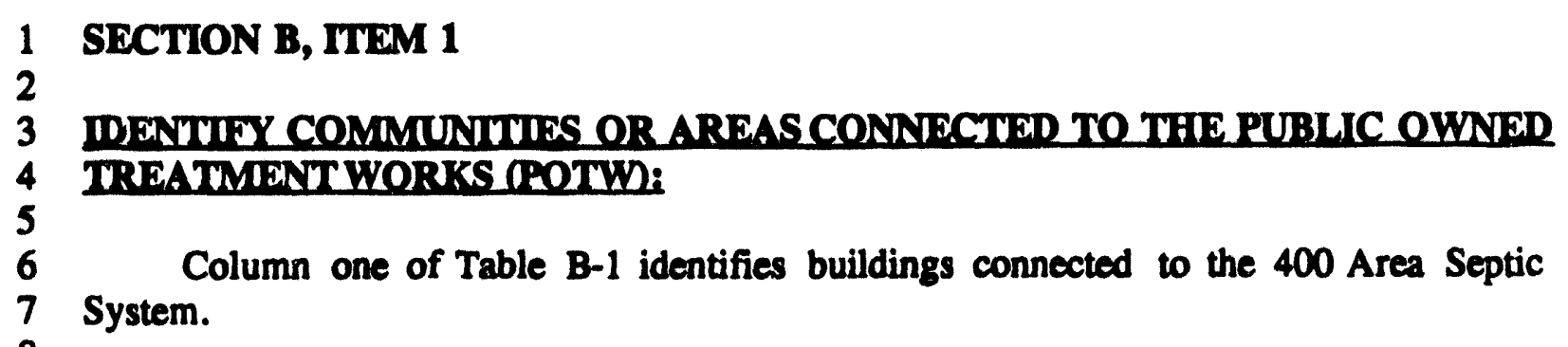

3 IDENTIEY COMMUNITIES OR AREAS CONNTCTIED TO THE PUBLC OWNED

4 TREATMMENTWORKS POOTW: System.

Column one of Table B-1 identifies buildings connected to the 400 Area Septic

5

6

7

\section{SECTION B, ITEM 2}

\section{IDENTIFY ALL INDUSTRIES CONNECTED TO THE POTW OR TO THE COLLECTION SYSTEM BY TYPE OF INDUSTRY, NAME, ADDRESS, AND TELEPHONE NUMBER, ATTACHEXTRA SHEET(S) IF NEEDED.}

Columns two, three, and four in Table B-1 identify building name, industries (types of buildings) connected to the 400 Area Septic System, and the 400 Area occupancy. The 400 Area buildings discharging waste to the 400 Area Infiltration Pond have been identified and classified as "administrative" or "process" buildings. Buildings that do not contain processes, and generate domestic waste water from bathroom and kitchen use only are classified as "administrative." Buildings with functions or purposes other than administrative are classified as "process" (even though they may only generate sanitary waste from bathroom and kitchen use). 
DOE/RL-94-28, Rev. 0

06/94

400 Aree Septic System

Table B-1. Bulldings Connected to the 400 Aren Septic System

(Sheet 1 of 1)

\begin{tabular}{|c|c|c|c|}
\hline $\begin{array}{l}\text { Building } \\
\text { Number }\end{array}$ & Building Name & $\begin{array}{l}\text { Building } \\
\text { Classifications }\end{array}$ & Occupancy \\
\hline 427 & FMEF & Administrative & \multirow[t]{22}{*}{700} \\
\hline 436 & 400 Area Training Building & Process & \\
\hline 437 & MASF & Administrative & \\
\hline 4701-A & Guard Station & Process & \\
\hline 4701-B & Guard Station & Administrative & \\
\hline $4701-C$ & Guard Station & Administrative & \\
\hline 4702 & Office Building & Administrative & \\
\hline 4703 & FFTF Control Building & Administrative & \\
\hline 4704-N & Computer Maintenance & Process & \\
\hline 4704-S & Fire Station & Administrative & \\
\hline 4706 & Support Services Building & Administrative & \\
\hline 4707 & Site Support Building & Administrative & \\
\hline $4 ? 10$ & Operations Support Building & Administrative & \\
\hline 4713-A & Maintenance and Storage & Administrative & \\
\hline 4713-B & Maintenance and Storage & Process & \\
\hline 4719 & Medical Aid Station & Process & \\
\hline 4722-B & Carpenter Shop & Administrative & \\
\hline $4722-C$ & Paint Shop & Process & \\
\hline $4732-A$ & Warehouse & Process & \\
\hline 4734-D & Warehouse & Process & \\
\hline 4790 & Patrol Headquarters & Process & \\
\hline 4862 & FMEF & Administrative & \\
\hline
\end{tabular}


DOE/RL-94-28, Rev. 0

06/94

400 Area Septic System

\section{SECTION B, ITEM 4a, 4b, and 4c.}

No original design data is available for the 400 Area Septic System. Information provided in Items $4 a, 4 b$, and $4 c$ are actual operational values. Data in Item $4 a$ is from the Bovay Engineering Report, (Bovay 1993). Data in Item $4 \mathrm{~b}$ is from the Characterization Report, (WHC 1993a). Data in Item $4 c$ is from recent sampling conducted by Westinghouse Hanford Company.

\section{SECTION B, ITEM 4 f}

\section{PLANNED REVISIONS (YEAR):}

As it is currently configured, the 400 Area sanitary sewer system domestic waste water receives primary treatment in the existing septic tank. The effluent is then gravity fed to an unlined infiltration pond north of the 400 Area.

There are two alternate discharge routes that are being considered for revision of the system. The first alternative involves the tie-in routing domestic waste water from the 400 Area to the Washington Public Power Supply System (WPPSS) Waste Water Treatment Facility which was installed in 1991 . However, the waste water flow was never intentionally routed through this line due to the lack of a formal contract with WPPSS. This tie-in is currently plugged.

DOE-RL has been negotiating a contract with representatives from WPPSS since the initial installation of the tie line. As of this time no agreement has been reached. Bovay Northwest was contracted to perform an engineering study to determine the best alternative solution for resolving the issue, should the DOE-RL/WPPSS negotiations fail to reach an agreement. The engineering study was distributed in September of 1993 (Bovay 1993).

The engineering study listed seven possible options for bringing the system into compliance. The study rated the seven recommendations based on capital cost, operating cost, future expandability, and regulatory considerations. After rating all of the options using the above criteria, the second alternative, a fully lined evaporative lagoon treatment system, was recommended if an agreement to connent the tie-in was not reached. This system would eliminate any discharges to the ground.

The evaporative lagoon will be able to accommodate future flows. This revision would use the existing septic tank, but would also add a new pump pit if required to accommodate future flows and populations. Funding for this project has been given priority for Fiscal Year 1995 General Plant Project funding. Should this funding be available for Fiscal Year 1995, the project would be completed in mid-1996. If Fiscal Year 1995 funding is not 
DOE/RL-94-28, Rev. 0

$06 / 94$

400 Area Seplic System

1 available, the routine funding process will be followed and the system would not be

2 operational until early 1998.

3

4

5 SECTION B, TTEM 5

6

7 ATTACH A SIMPUE SCHIMATIC DRAWING OF POTW INDICATING PROCESS

8 AND PROCESS DISCHARGE IN MGD (ATCACHMENTS SHOULD BE $11^{\prime \prime} \times 17^{\prime \prime}$. OR

9 SMALLER). NNCLUDE ALL UNIT PROCESSES IDENTIEIED NN OUESTION B.6.

10

11

A schematic drawing for the $\mathbf{4 0 0}$ Area Septic System is provided as Figure B-1. 
DOE/RL-94-28, Rev. 0

$06 / 94$

400 Area Septic System

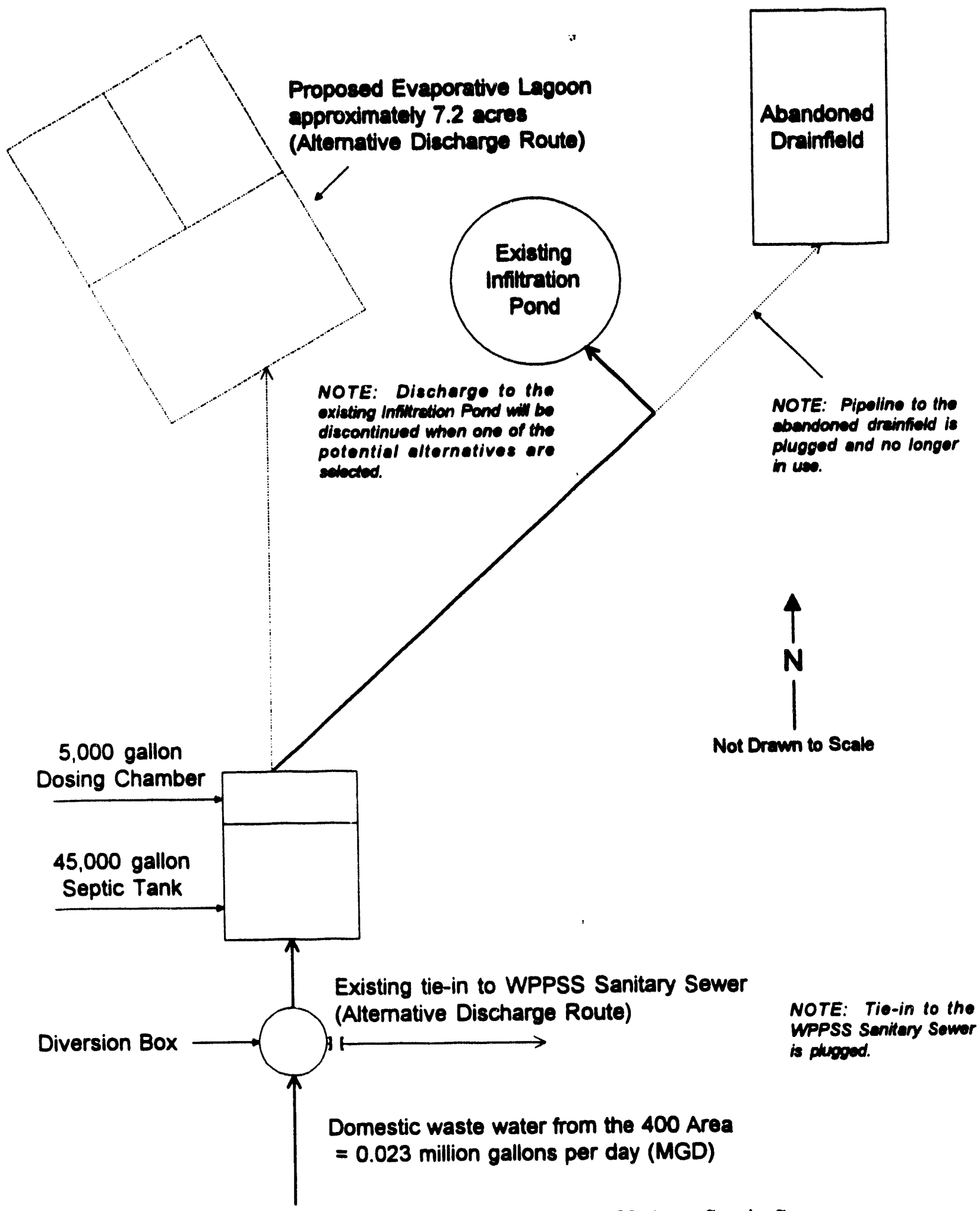

Figure B-1. Schematic Diagram for the 400 Area Septic System. 
DOE/RL-94-28, Rev. 0

06/94

400 Area Septic System

\section{APPENDIX C}

WASTE WATER INFORMATION

App C-i 
DOE/RL-94-28, Rev. 0 06/94

400 Area Septic System

This page intentionally left blank.

App C-ii 
DOE/RL-94-28, Rev. 0 $06 / 94$

400 Area Septic System

\title{
CONTENTS
}

\author{
SECTION C, TTEM 1 \\ PROVIDE MEASUREMENTS FOR TREATED WASTE WATER \\ PRIOR TO LAND APPLICATION FOR THE PARAMETERS \\ LISTED BELOW, UNLESS WAIVED BY THE PERMITTING \\ AUTHORTYY. ALL ANALYTICAL METHODS USED TO MEET \\ THESE REQUIREMENTS SHALL, UNLESS APPROVED \\ OTHERWISE IN WRITING BY ECOLOGY, CONFORM TO THE \\ GUIDELINES ESTABLISHING TEST PROCEDURES FOR THE \\ ANALYSIS OF POLLUTANTS CONTAINED IN \&O CER PART 136, ....... C-1 \\ SECTION C, ITEM 2 \\ HAS THE EFFLUENT BEEN ANALYZED FOR ANY OTHER \\ PARAMETERS THAN THOSE IDENTIFIED IN QUESTION C.1? \\ IF SO, WHEN? ATTACH RESULTS. NOTE: ECOLOGY MAY \\ REQUIRE ADDITIONAL TESTING.) $\ldots \ldots \ldots \ldots \ldots \ldots \ldots \ldots \ldots \ldots \ldots$ C-1
}

\section{TABLE}

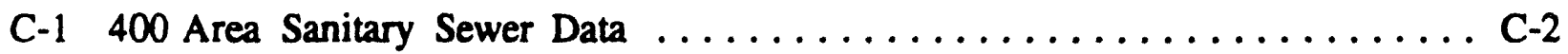


DOE/RL-94-28, Rev. 0 06/94

400 Area Septic System

This page intentionally left blank. 
DOE/RL-94-28, Rev. 0

06/94

400 Area Septic System

\section{SECTION C}

\section{SECTION C, ITEM 1}

PROVIDE MEASUREMENTS FOR TREATED WASTE WATER PRIOR TO LAND

APPLICATIONFOR THE PARAMETERS UISTED BELOW. UNLESS WAIVED BY THE PERMTIUTNG AUTHORTTY. ALL ANALYTCAL METHODS USFD TO MEET THIESE REOUTREMENTS SHALL, UNLESS APPROVED OTHERWISE IN WRTTING BY ECOLOGY. CONFORM TO THE GUIDELINES ESTABLISHING TEST PROCEDURES FOR THE ANALYSIS OE POLLUTANTS CONTAINED IN 40 CER PART 136.

\section{SECTION C, ITEM 2}

\section{HAS THE EFELUENT BEEN ANALYZED FOR ANY OTHER PARAMETERS THAN THOSE IDENTIFIED IN OUESTION C.1? IF SO. WHEN? ATTACH RESULTS, NOTE: ECOLOGY MAY REOUIRE ADDITIONAL TESTING.)}

The samples and resultant data presented in Table C-1 were obtained in accordance with a sampling and analysis plan (WHC 1993b). The data confirm process knowledge information and show that the stream is consistent with the expected effluent from typical septic tank treatment systems. The constituent concentrations are consistent with typical waste water streams as discussed in Metcalf and Eddy (1991) and the EPA design manual (EPA 1980).

Two constituents, iron $(\mathrm{Fe})$ and manganese $(\mathrm{Mn})$ were measured above the WAC-173-200 Ground Water Quality Criteria (GWQC). Iron was detected at $6620 \mathrm{ug} / \mathrm{L}$ $(G W Q C=300 \mathrm{ug} / \mathrm{L})$. Manganese was detected at $149 \mathrm{ug} / \mathrm{L}(\mathrm{GWQC}=50 \mathrm{ug} / \mathrm{L})$. The source of these metals is not known for certainty, but is thought to be the metal piping within the 400 Area. 
DOE/RL-94-28, Rev. 0 06/94

Table C-1. 400 Area Sanitary Sewer Data.

400 Area Septic System

Sheet 1 of 3

\begin{tabular}{|c|c|c|c|c|c|c|}
\hline \multicolumn{7}{|c|}{ BFFLUENT ' } \\
\hline CONSTITUENT & o & $\begin{array}{l}\text { MEAN } \\
\text { CONC. }\end{array}$ & S.D. & UNITS & METHOD • & D.L. \\
\hline \multicolumn{7}{|c|}{ Waste Water Parameters d } \\
\hline Conductivity & 2 & 952 & 11 & umho/cm & 120.1 & 6 \\
\hline $\mathrm{pH}$ & 2 & 7.4 (J2) & N/A & $\mathrm{pH}$ & 9040 & 0.1 \\
\hline TDS & 2 & 438 & 15 & $\mathrm{mg} / \mathrm{L}$ & 160.1 & 5 \\
\hline TSS & 2 & 348 & 342 & $\mathrm{mg} / \mathrm{L}$ & 160.2 & 5 \\
\hline BOD & 2 & 190 & N/A & $\mathrm{mg} / \mathrm{L}$ & 5210 & 2 \\
\hline TKN & 2 & 78.4 & 2.0 & $\mathrm{mg} / \mathrm{L}$ & 351.3 & 1.0 \\
\hline Total Phosphorous & 2 & 7.1 & 0.4 & $\mathrm{mg} / \mathrm{L}$ & 365.2 & 0.05 \\
\hline $\begin{array}{l}\text { Total Oil and } \\
\text { Grease }\end{array}$ & 2 & 99 & 104 & $\mathrm{mg} / \mathrm{L}$ & 9070 & 5 \\
\hline $\begin{array}{l}\text { Coliform Bacteria } \\
\text { (Bact.) }\end{array}$ & 2 & ND & N/A & $\begin{array}{l}\text { Bact./ } \\
100 \mathrm{ml}\end{array}$ & $9131 / 9132$ & 1 \\
\hline \multicolumn{7}{|l|}{ Metals } \\
\hline $\mathrm{Ca}$ & 2 & 45750 & 919 & $\mathrm{ug} / \mathrm{L}$ & 6010 & $10(\mathrm{P})$ \\
\hline $\mathbf{M g}$ & 2 & 12200 & 282 & $\mathrm{ug} / \mathrm{L}$ & 6010 & $30(\mathrm{P})$ \\
\hline $\mathrm{Na}$ & 2 & 52200 & 989 & $\mathrm{ug} / \mathrm{L}$ & 6010 & $29(\mathrm{P})$ \\
\hline $\mathbf{K}$ & 2 & 25700 & 424 & $\mathrm{ug} / \mathrm{L}$ & 6010 & 5000 \\
\hline $\mathrm{Cd}$ & 2 & $1.9(\mathrm{U}, \mathrm{B})$ & 0.2 & $\mathrm{ug} / \mathrm{L}$ & 6010 & 1.7 \\
\hline $\mathrm{Cr}$ & 2 & $10.4(\mathrm{~B} 1)$ & 0.7 & $\mathrm{ug} / \mathrm{L}$ & 6010 & $7(\mathrm{P})$ \\
\hline $\mathrm{Pb}$ & 2 & $17.3(\mathrm{~B} 2)$ & 0.1 & $\mathrm{ug} / \mathrm{L}$ & 6010 & 11 \\
\hline $\mathrm{Se}$ & 2 & 33 (U2) & N/A & $\mathrm{ug} / \mathrm{L}$ & 6010 & 33 \\
\hline $\mathrm{Ag}$ & 2 & 2.1 (UJ2) & N/A & $\mathrm{ug} / \mathrm{L}$ & 6010 & 2.1 \\
\hline $\mathrm{Cu}$ & 2 & 145 & 3 & $\mathrm{ug} / \mathrm{L}$ & 6010 & $6(\mathrm{P})$ \\
\hline $\mathrm{Fe}$ & 2 & 6620 & 877 & $\mathrm{ug} / \mathrm{L}$ & 6010 & 7 (P) \\
\hline
\end{tabular}


DOE/RL-94-28, Rev. 0

Table C-1. 400 Area Sanitary Sewer Data.

Sheet 2 of 3

\begin{tabular}{|c|c|c|c|c|c|c|}
\hline \multicolumn{2}{|c|}{ ?. } & \multicolumn{2}{|c|}{ EFFLUENT } & \multirow[b]{2}{*}{ UNTTS } & \multirow[b]{2}{*}{ METHOD • } & \multirow[b]{2}{*}{ D.L. } \\
\hline CONSTITUENT & n & $\begin{array}{l}\text { MEAN } \\
\text { CONC. }\end{array}$ & S.D. & & & \\
\hline \multicolumn{7}{|c|}{ Metals (continued) } \\
\hline Mn & 2 & 149 & 13 & ug $/ \mathrm{L}$ & 6010 & $2(\mathrm{P})$ \\
\hline $\mathrm{Zn}$ & 2 & 1225 & 7 & $u g / L$ & 6010 & $2(\mathrm{P})$ \\
\hline $\mathrm{Ba}$ & 2 & 269 & 4 & $\mathrm{ug} / \mathrm{L}$ & 6010 & $2(\mathrm{P})$ \\
\hline As & 2 & $15.6(\mathrm{U}, \mathrm{B})$ & 0.1 & $\mathrm{ug} / \mathrm{L}$ & 6010 & $1(\mathrm{P})$ \\
\hline \multicolumn{7}{|l|}{ Anions } \\
\hline $\mathrm{Fl}^{-}$ & 2 & 0.5 & 0.3 & $\mathrm{mg} / \mathrm{L}$ & 300.0 & 0.1 \\
\hline $\mathrm{Cl}^{-}$ & 2 & 44 & 3 & $\mathrm{mg} / \mathrm{L}$ & 300.0 & 2 \\
\hline $\mathrm{SO}_{4}=$ & 2 & 36 & 3 & $\mathrm{mg} / \mathrm{L}$ & 300.0 & $2-10$ \\
\hline $\mathrm{NO}_{2}=\mathrm{NO}_{3}^{-}$ & 2 & 0.44 & 0.06 & $\mathrm{mg} / \mathrm{L}$ & 353.2 & 0.05 \\
\hline \multicolumn{7}{|l|}{ Screening } \\
\hline TOC & 3 & 93 & 1 & $\mathrm{mg} / \mathrm{L}$ & 9060 & 1 \\
\hline TOX & 2 & $0.50(\mathrm{U})$ & N/A & $\mathrm{mg} / \mathrm{L}$ & 9020 & 0.50 \\
\hline \multicolumn{7}{|l|}{ Radionuclides $^{\mathrm{C}}$} \\
\hline Gross Alpha & 2 & 7.9 (J2) & 4.4 & $\mathrm{pCi} / \mathrm{L}$ & EP-10 & $2-3$ \\
\hline Gross Beta & 2 & $27(\mathrm{~J} 2)$ & 3.5 & $\mathrm{pCi} / \mathrm{L}$ & EP-10 & $2-4$ \\
\hline Tritium & 2 & 6650 & 71 & $\mathrm{pCi} / \mathrm{L}$ & EP-20 & 200 \\
\hline Sr-89 & 2 & $0.15(\mathrm{U} 2)$ & 0.09 & $\mathrm{pCi} / \mathrm{L}$ & $\begin{array}{l}\text { RC-303,304 } \\
306,309\end{array}$ & 0.5 \\
\hline Sr-90 & 2 & $-0.32(\mathrm{U} 2)$ & 0.55 & $\mathrm{pCi} / \mathrm{L}$ & $\begin{array}{l}\text { RC-303,304 } \\
306,309\end{array}$ & $0.9-1$ \\
\hline
\end{tabular}




\section{Table C-1. 400 Area Sanitary Sewer Data.} Sheet 3 of 3

$$
\begin{aligned}
& \text { BOD = Biologica Oxygen Demand } \\
& \text { PAH = Polycyclic Aromatic Hydrocarbons } \\
& \text { SVOC }=\text { Semi-Volatile Organic Compound } \\
& \text { TDS }=\text { Total Dissolved Solids } \\
& \text { TIC }=\text { Tenatively Identified Compound } \\
& \text { TKN }=\text { Total Kjeldahl Nitrogen } \\
& \text { TOC }=\text { Total Organic Carbon } \\
& \text { TOX }=\text { Total Organic Halide } \\
& \text { TSS = Total Suspended Solids } \\
& \text { VOC = Volatile Organic Compound }
\end{aligned}
$$

$$
\begin{aligned}
& \mathrm{mg} / \mathrm{L}=\text { milligrams per liter } \\
& \mathrm{pCi} / \mathrm{L}=\text { picocuries per liter } \\
& \text { ug } /=\text { micrograms per liter } \\
& \text { umho/cm }=\text { micromhos per centimeter } \\
& \text { N/A = Not Applicable } \\
& \text { ND }=\text { Not Detected }
\end{aligned}
$$

a $\quad n=$ Number of sample results averaged. mean conc $=$ mean concentration S.D. = one standard deviation about the mean

b Three digit numbers with a decimal (i.e., 120.1, 300.0 etc.) are from EPA 1979. Four digit procedure numbers (i.e., 6010, 9131 etc.) are from EPA 1992. Four digit numbers with a letter following (i.e., 5210B) are from "Standard Methods for the Examination of Water and Wastewater", 18th Edition, (APHA, 1992). with the data.

d Qualifiers which may appear in this table are:

(U) - Indicates the compound or analyte was analyzed for and not detected in the sample. The value reported is the sample quantitation limit (D.L.) corrected for sample dilution by the laboratory.

(J) - Indicates the compound or analyte was analyzed for and detected, but due to a QC deficiency identified during data validation, the associated quantitation limit is an estimate. This flag is also used when estimating concentrations of TICs or when the presence of a target compound is confirmed at a concentration of less than the D.L. but greater than the instrument detection limit.

(B) - This flag applies to results in which the analyte was detected in both the sample and the associated blank. For the metals, (B) also indicates the analyte concentration is less than the D.L. but greater than the instrument detection level.

Data qualifiers may appear in combinations. An alpha numeric combination (i.e., U2) indicates that two of the sample results used in the mean had a (U) qualifier. Two qualifiers separated by a comma (i.e., B,U) indicates that one of the samples in the mean has a (B) qualifier and one has a (U) qualifier.

e Contractor internal laboratory procedures are used for radiochemical analysis. 
DOE/RL-94-28, Rev. 0

06/94

400 Area Soptic System

\section{APPENDIX D}

SLUDGE MANAGEMENT AND DISPOSAL

App D-i 
DOE/RL-94-28, Rev. 0 06/94

400 Aren Septic System

This page intentionally left blank. 
DOE/RL-94-28, Rev. 0 06/94

400 Arm Septic Syetom

\section{CONTENTS}

\section{SECTION D, ITEM 1}

SLUDGE MANAGEMENT PLAN $\ldots \ldots \ldots \ldots \ldots \ldots \ldots \ldots \ldots \ldots$ D-1 
DOE/RL-94-28, Rev. 0 06/94

400 Area Septic Syetem

This page intentionally left blank. 
DOE/RL-94-28, Rev. 0 $06 / 94$

400 Area Septic System

1 SECTION D, ITEM 1

2

3 SLUDGEMANAGRMENTPLAN

4

5 Implementation of the revisions to the system that were discussed in Appendix B, 6 Item 4f, will include a fully compliant Sludge Management Plan. 
DOE/RL-94-28, Rev. 0 06/94

400 Area Septic Syatem

1

2

3

4

5

6

This page intentionally left blank.

D-2 
DOE/RL-94-28, Rev. 0 06/94

400 Area Septic System

APPENDIX E

STTE ASSESSMENT 
DOE/RL-94-28, Rev. 0

06/94

400 Area Septic System

1

2

3

4

5

6

This page intentionally left blank. 
DOE/RL-94-28, Rev. 0

06/94

400 Area Septic System

\section{CONTENTS}

SECTION E, ITEM 1

GIVE THE LEGAL DESCRIPTION OF THE LAND TREATMENT

SITE(S). GIVE THE ACREAGE OF EACH LAND TREATMENT

SITE(S). ATTACH A COPY OF THE CONTRACT(S)

AUTHORIZING USE OF THE LAND FOR TREATMENT. $\ldots \ldots \ldots \ldots \ldots \ldots$ E-1

SECTION E, ITEM 2

LIST ALL ENVIRONMENTAL CONTROL PERMITS OR

APPROVALS NEEDED FOR THIS PROJECT; FOR EXAMPLE, SEPTIC TANK PERMITS, SLUDGE APPLICATION PERMITS,

OR AIR EMISSIONS PERMITS.

SECTION E, ITEM 3

ATTACH A UNITED STATES GEOLOGICAL SURVEY (USGS)

TOPOGRAPHIC MAP. SHOW THE FOLLOWING ON THIS MAP:

SECTION E, ITEM 4

ATTACH WELL LOGS AND WELI I.D.\# WHEN AVAILABLE

FOR ALL WELLS WITHIN 500 . EET AND ANY AVAILABLE

WATER QUALITY DATA.

SECTION E, ITEM 5

DESCRIBE SOILS ON THE SITE USING INFORMATION FROM

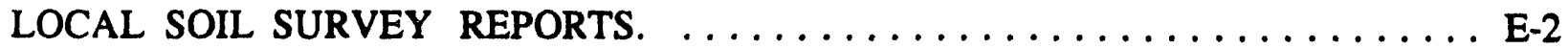

SECTION E, ITEM 6

DESCRIBE THE REGIONAL GEOLOGY AND HYDROGEOLOGY

WITHIN ONE MILE OF THE SITE. $\ldots \ldots \ldots \ldots \ldots \ldots \ldots \ldots \ldots \ldots$ E-5

SECTION E, ITEM 7

LIST THE NAMES AND ADDRESSES OF CONTRACTORS OR CONSULTANTS WHO PROVIDED INFORMATION AND CITE

SOURCES OF INFORMATION BY TITLE AND AUTHOR.

TABLE

E-1 Analytical Data for Well $699-2-7 \ldots \ldots \ldots \ldots \ldots \ldots \ldots \ldots \ldots$ E-3 
DOE/RL-94-28, Rev. 0 06/94

400 Area Septic System

\section{EIGURES}

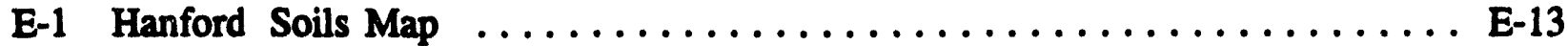

E-2 Soils Map for the 400 Area Septic System $\ldots \ldots \ldots \ldots \ldots \ldots \ldots \ldots$ E-14

E-3 Hanford Geologic Map .......................... E-15

E-4 Legend for Hanford Geologic Map $\ldots \ldots \ldots \ldots \ldots \ldots \ldots \ldots \ldots$ E-16

E-5 Regional Stratigraphic Column $\ldots \ldots \ldots \ldots \ldots \ldots \ldots \ldots \ldots \ldots \ldots$ E-17

E-6 Geology Map for the 400 Area Septic System $\ldots \ldots \ldots \ldots \ldots \ldots \ldots$ E-18

E-7 Line of Cross-Section for the 400 Area $\ldots \ldots \ldots \ldots \ldots \ldots \ldots \ldots$ E-19

E-8 Cross-Section for the 400 Area $\ldots \ldots \ldots \ldots \ldots \ldots \ldots \ldots \ldots \ldots$ E-20

E-9 Hanford Water Table Map $\ldots \ldots \ldots \ldots \ldots \ldots \ldots \ldots \ldots \ldots \ldots$ E-21 
DOE/RL-94-28, Rev. 0 $06 / 94$

400 Area Septic System

\section{SECTION E, ITEM 1}

GIVE THE LEGALDESCRIPTION OF THE LAND TREATMENT SITE(S), GIVE THE ACREAGEOF EACH LAND TREATMENTS STTE(S). ATTACHA COPY OF THE CONTRACT(S) AUTHORIZING USE OF THE LAND FOR TREATMENT.

Legal Description:

SW 1/4, NE 1/4, Section 18, Township 11N, Range 28E, Benton County, WA.

The land treatment site has the following acreage:

400 Area Infiltration Pond (Total Area): 0.10 acre

A specific contract authorizing use of the 400 Area Infiltration Pond for a land treatment site does not exist, but the Hanford Site was created by the U.S. Government to serve as a research and production facility for federal government nuclear projects.

18 The Hanford Site has been in use since the early 1940's and all disposal facilities, such as the 400 Area Infiltration Pond, have been authorized by the U.S. Government.

\section{SECTION E, ITEM 2}

\section{LIST ALL ENVIRONMENTAL CONTROL PERMITS OR APPROVALS NEEDED FOR THIS PROJECT: FOR EXAMPLE. SEPTIC TANK PERMITS, SLUDGE APPLICATION PERMITS, OR AIR EMISSIONS PERMITS.}

There are no additional permits specifically required for this system in its current configuration. The following permits are general permits for the Hanford Site.

- Hanford Site Radioactive Air Emissions Permit: Number FF-01

- Hanford Site Dangerous Waste Permit: Number WA7890008967

- National Pollutant Discharge Elimination System General Permit: Number WA-R-00-A17F.

The planned revision discussed in Appendix B, Item $4 \mathrm{f}$ will require submittal of a 240-Engineering Report and all of the required authorizations will be obtained prior to beginning construction. 
DOE/RL-94-28, Rev. 0

06/94

400 Area Septic System

\section{SECTION E, ITEM 3}

\section{ATTACH A UNITED STATES GEOLOGICALSURVEY (USGS) TOPOGRAPHIC MAP. SHOW THE FOULOWING ON THIS MAP:}

a. Location and name of internal and adjacent streets

b. Surface water drainage systems within 1/4 mile of the site

c. All wells within 1 mile of the site

d. Chemical and product handling and storage facilities

e. Infiltration sources, such as drain fields and lagoons within 1/4 mile of the site

f. Waste water discharge points (DP) including bypasses

g. Other activities and land uses within 1/4 mile of the site.

Drawing H-13-000098 addresses the above items as applicable. Although this drawing is not a USGS topographic map, it was derived from the Hanford Site topographic map database. The Hanford Site map database provides more detail and allows the items to be addressed at a more appropriate scale than a USGS map. The waste water discharge point shown for the waste stream on Drawing H-13-000098 includes all component substreams prior to discharge. No chemical or product handling and storage areas are related directly to the disposal areas, thus none are shown on Drawing H-13-000098. The 400 Area Percolation Ponds, which are part of the process sewer system, are located within $1 / 4$ mile of the 400 Area Infiltration Pond.

\section{SECTION E, ITEM 4}

ATTACH WELLLOGS AND WELL I.D.\# WHEN AVAILABLE FOR ALL WELLS WITHIN 500 FEET AND ANY AVAILABLE WATER QUALITY DATA.

The only well within 500 feet of the 400 Area Infiltration Pond is 699-2-7. Available analytical data for well 699-2-7 is presented in Table E-1. No well log is available for well 699-2-7.

\section{SECTION E, ITEM 5}

\section{DESCRIBE SOILS ON THE SITE USING INFORMATION FROM LOCALSOIL SURVEYREPORTS.}

The most recent study of the soil on the Hanford Site was done by Hajek (1966). This study presents a soil map and descriptive report of soils in the Benton County portion of the Hanford Site. On the basis of morphologic and genetic characteristics, 13 soil types were identified. An approximate land use capability classification is provided for these soils on the basis of soil limitations for, and damage risks associated with, 
DOE/RL-94-28, Rev. 0 06/94

Table E-1. Analytical Data for Well 699-2-7.' (Sheet 1 of 2)

\begin{tabular}{|c|c|c|c|c||}
\hline DATB & ANALYTE & CODE $^{2}$ & VALUE & UNITS \\
\hline 03-Mar-86 & Nitrate & & 96 & $\mathrm{mg} / \mathrm{L}$ \\
\hline 24-Jun-86 & Nitrate & & 69 & $\mathrm{mg} / \mathrm{L}$ \\
\hline 13-Aug-86 & Nitrate & & 37,200 & $\mathrm{ppb}$ \\
\hline 07-Nov-86 & Nitrate & & 33,400 & $\mathrm{ppb}$ \\
\hline 26-Jan-87 & Nitrate & & 34,300 & $\mathrm{ppb}$ \\
\hline 31-May-87 & Nitrate & & 28,300 & $\mathrm{ppb}$ \\
\hline 24-Jul-87 & Nitrate & & 32,900 & $\mathrm{ppb}$ \\
\hline 21-Oct-87 & Nitrate & & 48,600 & $\mathrm{ppb}$ \\
\hline 27-Jan-88 & Nitrate & & 39,900 & $\mathrm{ppb}$ \\
\hline 30-Jan-89 & Nitrate & & 55,500 & $\mathrm{ppb}$ \\
\hline 13-Apr-90 & Nitrate & & 73,400 & $\mathrm{ppb}$ \\
\hline 18-Dec-91 & Nitrate & & 15,000 & $\mathrm{ppb}$ \\
\hline 07-Feb-92 & Nitrate & & 69,000 & $\mathrm{ppb}$ \\
\hline 30-Apr-92 & Nitrate & & 78,000 & $\mathrm{ppb}$ \\
\hline 18-Aug-92 & Nitrate & & 82,000 & $\mathrm{ppb}$ \\
\hline 03-Dec-92 & Nitrate & & 83,000 & $\mathrm{ppb}$ \\
\hline 02-Feb-93 & Nitrate & & 79,000 & $\mathrm{ppb}$ \\
\hline 14-May-93 & Nitrate & & 88,000 & $\mathrm{ppb}$ \\
\hline 19-Aug-93 & Nitrate & & 78,000 & $\mathrm{ppb}$ \\
\hline 18-Nov-93 & Nitrate & & 93,000 & $\mathrm{ppb}$ \\
\hline 03-Mar-86 & Tritium & & 16,000 & $\mathrm{pCi/L}$ \\
\hline 24-Jun-86 & Tritium & $\mathrm{U}$ & 13,000 & $\mathrm{pCi} / \mathrm{L}$ \\
\hline 13-Aug-86 & Tritium & & 12,900 & $\mathrm{pCi} / \mathrm{L}$ \\
\hline 07-Nov-86 & Tritium & & 12,100 & $\mathrm{pCi/L}$ \\
\hline
\end{tabular}


DOE/RL-94-28, Rev. 0

06/94

400 Area Septic System

Table E-1. Analytical Data for Well 699-2-7!

(Sheet 2 of 2)

\begin{tabular}{|c|c|c|c|c|}
\hline DATE & ANALYTE & CODE $^{2}$ & VALUE & UNITS \\
\hline $26-J a n-87$ & Tritium & & 6,790 & $\mathrm{pCi} / \mathrm{L}$ \\
\hline $31-M a y-87$ & Tritium & & 10,900 & $\mathrm{pCi} / \mathrm{L}$ \\
\hline $24-J u l-87$ & Tritium & & 10,700 & $\mathrm{pCi} / \mathrm{L}$ \\
\hline $21-$ Oct-87 & Tritium & & 13,300 & $\mathrm{pCi} / \mathrm{L}$ \\
\hline $27-J a n-88$ & Tritium & & 13,300 & $\mathrm{pCi} / \mathrm{L}$ \\
\hline 30-Jan-89 & Tritium & & 12,300 & $\mathrm{pCi} / \mathrm{L}$ \\
\hline 13-Apr-90 & Tritium & & 14,300 & $\mathrm{pCi} / \mathrm{L}$ \\
\hline $21-$ Mar-91 & Tritium & & 11,900 & $\mathrm{pCi} / \mathrm{L}$ \\
\hline 18-Dec-91 & Tritium & & 12,200 & $\mathrm{pCi} / \mathrm{L}$ \\
\hline 18-Dec-91 & Tritium & & 12,300 & $\mathrm{pCi} / \mathrm{L}$ \\
\hline $07-$ Feb-92 & Tritium & & 11,700 & $\mathrm{pCi} / \mathrm{L}$ \\
\hline 30-Apr-92 & Tritium & & 13,100 & $\mathrm{pCi} / \mathrm{L}$ \\
\hline 18-Aug-92 & Tritium & & 13,500 & $\mathrm{pCi} / \mathrm{L}$ \\
\hline $03-$ Dec-92 & Tritium & & 13,100 & $\mathrm{pCi} / \mathrm{L}$ \\
\hline 02-Feb-93 & Tritium & & 14,100 & $\mathrm{pCi} / \mathrm{L}$ \\
\hline 14-May-93 & Tritium & & 14,500 & $\mathrm{pCi} / \mathrm{L}$ \\
\hline 19-Aug-93 & Tritium & & 15,100 & $\mathrm{pCi} / \mathrm{L}$ \\
\hline 18-Nov-93 & Tritium & & 15,100 & $\mathrm{pCi} / \mathrm{L}$ \\
\hline
\end{tabular}

'Source: Westinghouse Hanford Company Geohydrology Support Functions GeoDAT Database

${ }^{2}$ Code: $\mathrm{U}=$ Undetected 
1 agricultural use. Approximate engineering classifications for these soils, using the

2 Unified Soil Classification System, are also provided in Hajek (1966). The soil types

3 mapped on the Hanford Site are shown on Figure E-1. There is no soil data for the 4 north slope of the Hanford Site. The soil present in the vicinity of the 400 Area consists 5 of the Quincy sand (Rupert sand) and a small amount of Burbank loamy sand. A map 6 depicting the soils within one mile of the 400 Area Infiltration Pond is provided as 7 Figure E-2.

The Quincy sand (Rupert sand) represents one of the most extensive soils at the Hanford Site. The soil is a brown to grayish brown, moderately deep, coarse sand. Quincy soils will develop under grass and sagebrush in coarse alluvial deposits mantled by wind-blown sand. Relief characteristically consists of hummocky terraces and dunelike ridges. The surface and subsoil of the Quincy sand (Rupert sand) were assigned to Group SM (silty sand), which consists of coarse-grained soils composed predominantly of sands with more than 12 percent fines.

The Burbank loamy sand is a dark grayish brown, coarse-textured, excessively drained soil underlain by gravel. The surface soil is usually about 16 inches thick, but can be as much as 30 inches. The gravel content of the subsoil may range from 20 to 80 percent (by volume). The surface of the Burbank loamy sand is Group SM (silty sand) and the subsoil is Group GM (silty gravel) to GP (poorly graded gravel). Group GM (silty gravel) are coarse-grained soils composed predominantly of gravels with more than 12 percent fines. Group GP (poorly graded gravel) contains coarse-grained soils that are predominantly well-sorted gravels with less than 5 percent fines.

\section{SECTION E, ITEM 6}

\section{DESCRIBE THE REGIONAL GEOLOGY AND HYDROGEOLOGY WITHIN ONE MILE OF THE SITE.}

\section{REGIONAL GEOLOGY}

A summary of the regional geologic characteristics of the Pasco Basin and the Hanford Site is presented below in terms of stratigraphy and structure. WHC (1992b), WHC (1991b), and WHC (1991d) may be consulted for additional detail. Figure E-3 is a map depicting the geology of the Hanford Site. Figure E-4 is a legend explaining Figure E-3. 
DOE/RL-94-28, Rev. 0

06/94

400 Area Septic Syatom

\section{REGIONAL STRATIGRAPHY}

The Hanford Site lies within the Pasco Basin, a regional structural and topographic, sediment-filled depression. The sediments of the Pasco Basin are underlain by Miocene-age basalt of the Columbia River Basalt Group, a thick sequence of flood basalts that covers a large area in eastern Washington, westem Idaho and northeastern Oregon. The sediments overlying the basalts, from oldest to youngest, include: the Miocene-Pliocene Ringold Formation, local alluvial deposits of possible late Pliocene or probable early Pleistocene age, local "Palouse" soil of mostly colian origin, glaciofluvial deposits of the Pleistocene Hanford formation, and surficial Holocene colian and fluvial sediments. The generalized stratigraphy of the Hanford Site is described from the oldest to youngest formation in the following paragraphs. The regional stratigraphy is depicted on Figure E-5.

\section{Columbia River Basalt Group and the Ellensburg Formation}

The Columbia River Basalt Group consists of an assemblage of tholeiitic, continental flood basalts of Miocene Age with an accumulated thickness in excess of 10,000 feet within the Pasco Basin. These flows cover an area of more than 63,000 square miles in Washington, Oregon, and Idaho and have an estimated volume of about 40,800 cubic miles. The majority of the flows were erupted 14.5 to 17 million years ago (WHC 1991b).

The Columbia River Basalt Group is formally divided into five formations (from oldest to youngest): Imnaha Basalt, Picture Gorge Basalt, Grande Ronde Basalt, Wanapum Basalt, and Saddle Mountains Basalt. Of these, all are present within the Pasco Basin except for the Picture Gorge Basalt. The Saddle Mountains Basalt, is divided into seven members (from oldest to youngest); the Umatilla, Wilbur Creek, Asotin, Esquatzel, Pomona, Elephant Mountian, and Ice Harbor Members, and forms the uppermost basalt unit throughout most of the Pasco Basin. The Elephant Mountain Member is the uppermost unit beneath most of the Hanford Site, except near the 300 Area where the Ice Harbor Member is found and north of the 200 Areas where the Saddle Mountains Basalt has been eroded down to the Umatilla Member in the Gable Gap area (WHC 1991b). The Elephant Mountain Member has also been locally eroded in the vicinity of the northeast corner of the 200 East Area (WHC 1991b). On anticlinal ridges bounding the Pasco Basin, erosion has removed the Saddle Mountains Basalt, exposing the Wanapum and Grande Ronde basalts (WHC 1991b).

The Ellensburg Formation consists of all sedimentary units that occur between the basalt flows of the Columbia River Basalt Group in the central Columbia Basin (Reidel and Fecht 1981). The Ellensburg Formation generally consists of two main lithologies: volcaniclastics and siliciclastics. The volcaniclastics consist mainly of primary pyroclastic air fall deposits and reworked epiclastics derived from volcanic terrains west of the 
1 Columbia Plateau. Siliciclastic strata consist of clastic, plutonic, and metamorphic 2 detritus derived from the Rocky Mountain terrains to the east.

3

At the Hanford Site, the three uppermost units of the Ellensburg Formation are the Levy interted, the Rattlesnake Ridge interbed, and the Selah interbed. The Levy interbed is confined to the vicinity of the 300 Area. The Rattlesnake Ridge and Selah interbeds are found beneath most of the Hanford Site (WHC 1992d).

\section{Suprabasalt Sediments}

The suprabasalt sedimentary sequence at the Hanford Site is up to approximately 750 feet thick in the west-central Cold Creek syncline, while it pinches out against the anticlinal ridges that bound or are present within the Pasco Basin (WHC 1991a). The suprabasalt sediments are dominated by laterally extensive deposits of the late Miocene to Pliocene-age Ringold Formation and the Pleistocene-age Hanford formation. Locally occurring strata separating the Ringold and Hanford formations are assigned to the informally defined Plio-Pleistocene unit, early "Palouse" soil, and pre-Missoula gravels, which comprise the remainder of the sequence (DOE-RL 1993).

Ringold Formation. Overlying the Columbia River Basalt Group is the late Miocene to Pliocene-age Ringold Formation (Fecht et al. 1987, DOE 1988). The Ringold Formation accumulated to a thickness of up to 1,200 feet in the Pasco Basin (Tallman et al. 1979). On the Hanford Site, the Ringold Formation is up to 600 feet thick in the deepest part of the Cold Creek syncline south of the 200 West Area and 560 feet thick in the western Wahluke syncline near the 100-B Area (WHC 1991b). The Ringold Formation pinches out against the anticlinal flanks that bound or are present within the Pasco Basin, and is largely absent in the northern and northeastern parts of the 200 East Area and adjacent areas to the north (WHC 1991b, WHC 1992b). The recent studies of the Ringold Formation (WHC 1991c) indicate it is best described on the basis of sediment facies associations and their distribution. The facies associations have been divided into fluvial gravel, fluvial sand, overbank deposits, lacustrine deposits, and alluvial fans. The lower Ringold contains five separate stratigraphic intervals dominated by fluvial gravels, which have been designated units A, B, C, D, and E, from oldest to youngest. These gravel units are separated by basin-wide overbank and lacustrine deposits (WHC 1992b). A more detailed discussion of the Ringold Formation stratigraphy can be found in WHC (1991c).

Post-Ringold Pre-Hanford Sediments. Thin alluvial deposits situated stratigraphically between the Ringold Formation and Hanford formation are found within the Pasco Basin. The three informally defined units include: the Plio-Pleistocene unit, the early "Palouse" soil, and the Pre-Missoula gravels. The Plio-Pleistocene unit and early "Palouse" soil are not found in or near the 200 East Area; they are found to the west of the site area near the eastern boundary of the 200 West Area. The preMissoula gravels are not found in the site area. The Plio-Pleistocene unit and early 
1 "Palouse" soil are described in detail in PNL (1989) and WHC (1991d). The pre-

2 Missoula gravels are discussed in PSPL (1982) and Fecht et al. (1987).

3

Hanford Formation. The informally designated Hanford formation consists of unconsolidated, glaciofluvial sediments that were deposited during several episodes of cataclysmic flooding during the Pleistocene Epoch. The sediments are composed of pebble- to boulder-size gravel, fine- to coarse-grained sand, and silt. These sediments are divided into three facies: gravel dominated, sand-dominated, and silt-dominated (WHC 1992b). These facies are referred to as coarse-grained deposits, plane-laminated sand facies, and rhythmite facies, respectively (Baker et al. 1991). The silt-dominated deposits are also referred to as "Touchet" Beds, and the gravel-dominated facies generally correspond to the Pasco gravels.

The Hanford formation is thickest in the vicinity of the 200 Areas where it is up to 350 feet thick (WHC 1992b). The formation was deposited by cataclysmic flood waters that originated from glacial lake Missoula (Fecht et al. 1987, DOE 1988, Baker et al. 1991). The deposits are absent from ridges above approximately 1,180 feet above mean sea level, the highest level of cataclysmic flooding in the Pasco Basin (WHC 1991b).

Holocene Surficial Deposits. Holocene surficial deposits consist of silt, sand, and gravel that form a $<16$-feet veneer across much of the Hanford Site. These sediments were deposited by eolian and alluvial processes (WHC 1991b).

\section{REGIONAL GEOLOGIC STRUCTURE}

The Hanford Site is located within the Pasco Basin near the eastern edge of the Yakima Fold Belt. The Yakima Fold Belt consists of a series of segmented, narrow, asymmetric, east-west trending anticlines separated by broad synclines or basins that, in many cases, contain thick accumulations of Neogene- to Quaternary-aged sediments (DOE 1988, Smith et al. 1989). The Pasco Basin is one of the larger structural basins of the fold belt.

The northern limbs of the anticlines of the Yakima Fold Belt generally dip steeply to the north or are vertical. The southern limbs generally dip at relatively shallow angles to the south. Thrust or high-angle reverse faults with fault planes that strike parallel or subparallel to the axial trends are principally found on the north sides of the anticlines. The amount of vertical stratigraphic offset associated with these faults varies (WHC 1991b).

Deformation of the Yakima Folds occurred under north-south compression and was contemporaneous with the eruption of the basalt flows. The fold belt was enlarging during the eruption of the Columbia River Basalt Group and continued to enlarge through the Pliocene, into the Pleistocene, and perhaps to the present (WHC 1991b). 
The Pasco Basin is a structural depression bounded on the north by the Saddle Mountain anticline; on the west by the Umtanum Ridge, Yakima Ridge, and Rattlesnake Hills anticlines; and on the south by the Rattlesnake Mountain anticline. The Palouse slope, a west-dipping monocline, bounds the Pasco Basin on the east. The Pasco Basin is divided into the Wahluke and Cold Creek synclines by the Gable Mountain anticline, the eastem extension of the Umtanum Ridge anticline.

The Cold Creek syncline lies between the Umtanum Ridge-Gable Mountain uplift and the Yakima Ridge uplift, and is an asymmetric and relatively flat-bottomed structure. The bedrock of the northern limb dips gently to the south, and the southern limb dips steeply to the north. The deepest parts of the Cold Creek syncline, the Wye Barricade depression, and the Cold Creek depression are located approximately 7.5 miles southeast of the 200 Areas and just to the west-southwest of the 200 West Area, respectively (Tallman et al. 1979).

\section{LOCAL GEOLOGY}

The three primary geologic units beneath the 400 Area are: the Elephant Mountain Member of the Saddle Mountains Basalt Formation, the Ringold Formation, and Hanford formation. The following discussion focuses on the suprabasalt sediments in the vicinity of the 400 Area. This information has been summarized from the Groundwater Impact Assessment Report for the 400 Area Ponds (WHC 1992). Figure E-6 is a map depicting the geology within one mile of the 400 Area Sanitary Lagoon. A local cross-section has also been included for more detailed information. The line of cross section is shown on Figure E-7 and the cross section is provided on Figure E-8.

\section{Saddle Mountain Basalt Formation}

The uppermost basalt flow in the 400 Area is the Elephant Mountain Member, which is located approximately 594 feet below ground surface. The basalt consists of flow breccia from a depth of 594 to 626 feet, underlaid by scoria to a depth of 641 feet. Hard dense basalt extends downward from the scoria to the bottom of the hole at 649 feet. The dense basalt contains horizontal to sub-horizontal flow structures and fractures dipping at 25 degrees.

\section{Ringold Formation}

The Ringold Formation overlies the Elephant Mountain Member Basalt. The Ringold Formation is approximately 262 feet thick and is composed of fluvial gravels and overbank and lacustrine deposits. The fluvial gravels are approximately 138 feet thick. Overlying the fluvial gravels are the overbank and lacustrine deposits, composed of thinly bedded silt and clay. The thickness of the overbank and lacustrine deposits is 
DOE/RL-94-28, Rev. 0

$06 / 94$

400 Area Septic System

1 approximately 219 feet. The contact between the Ringold Formation and the Hanford

2 formation is not well defined in the 400 area.

3

Overlying the overbank and lacustrine sediments are light brown and brown-gray silty sands that are both locally gravelly and clay-like. The thickness of sands is approximately 45 feet. Dense, light gray-brown fluvial sandy gravels overlie the silty sands and are approximately 39 to 69 feet thick. Because of the lack of stratigraphic detail in the $\mathbf{4 0 0}$ Area, this unit may be part of the Hanford formation.

\section{Hanford Formation}

The contact between the Ringold Formation and Hanford formation in the 400 area is not completely understood. The Hanford formation near the 400 Area appears to be dominated by the sand-dominated facies (WHC 1992c).

Overlying the Ringold Formation are dense, well-graded, gray gravelly sands consisting of light gray, fine to medium sand with some gravel. The thickness of this unit is up to 69 feet. Overlying the gravelly sands are horizontally stratified gray-brown, poorly graded, fine- to medium-grained dense sands that are locally silty and gravelly. Individual bedding layers range from a fraction of an inch to several inches. The thickness of the horizontally stratified sands ranges from 120 to 180 feet.

Under the 400 Area, the sand units have unique structural features known as "sand" dikes or clastic dikes. These dikes were encountered in excavations created during construction of the FFTF and are apparently common in the area. The dikes are composed of silt and sand in distinct bands (or beds) paralleling the dike walls and separated by a thin laminae of silty material. The width of the dikes ranges from several inches to six feet. The near-vertical deposits exhibit cross lamination and dewatering features. The vertical extent of the dikes is unknown. The dikes have been interpreted as non-tectonic structures related to rapid loading and unloading during cataclysmic flooding (Baker et al. 1991).

\section{Holocene Surficial Deposits}

The Hanford formation is overlain by eolian deposits that blanket the ground surface of the 400 Area. These deposits consist of five to 15 feet of eolian, fine- to medium-grained sand dunes characterized by cross-bedding. The sand is derived from the top of the Hanford formation, and is stabilized on the ground surface by growths of sagebrush and grass.

\section{REGIONAL HYDROGEOLOGY}

The hydrogeology of the Pasco Basin has been broadly characterized as consisting of four primary hydrogeologic units (DOE 1988). These units correspond to the upper 
1 three formations of the Columbia River Basalt Group (Grande Ronde Basalt, Wanapum

2 Basalt, and Saddle Mountains Basalt) and the suprabasalt sediments. The basalt

3 aquifers consist of the flood basalts of the Columbia River Basalt Group and relatively

4 minor amounts of intercalated fluvial and volcaniclastic sediments of the Ellensburg

5 Formation. Confined zones in the basalt aquifers are present in the sedimentary

6 interbeds and/or interflow zones that occur between dense basalt flows. The main

7 water-bearing portions of the interflow zones are networks of interconnecting vesicles

8 and fractures of the basalt flow tops and bottoms (DOE 1988).

The uppermost aquifer is part of a flow system that is local to the Pasco Basin, as are the uppermost basalt interbed aquifers (Gephart et al. 1979, DOE 1988). The uppermost aquifer system is regionally unconfined and occurs within the glaciofluvial sands and gravels of the Hanford formation and the fluvial/lacustrine sediments of the Ringold Formation. Confined to semi-confined aquifers of more limited extent also occur in the suprabasalt sediments of the Pasco Basin. These confined zones are generally located within the local flow system, between the unconfined aquifer and the underlying basalt surface. Groundwater in these aquifer systems is most likely recharged and discharged locally. Deeper in the basalt, interbed aquifer systems are part of the regional, or interbasin, flow system, which extends outside the margins of the Pasco Basin (DOE 1988). A water table map of the Hanford Site is provided as Figure E-9.

\section{LOCAL HYDROGEOLOGY}

The primary hydrostratigraphic units in the 400 Area are the confined aquifer system of the Saddle Mountain Basalt Formation and Ellensburg Formation, and the unconfined to confined aquifer system of the Ringold Formation and the $\mathrm{H}$ anford formation. The following discussion focuses on the hydrogeology of the suprabasalt sediments.

Sediments overlying the Elephant Mountain flow total approximately 600 feet thick. Approximately $\mathbf{4 4 0}$ feet of the lower portion of these sediments are saturated and comprise what is probably a single unconfined aquifer. Locally confined or semiconfined conditions may, however, be present within this unconfined aquifer in areas where relatively impermeable cemented or fine-grained materials act as confining layers. The water table of the unconfined aquifer is located roughly at the contact between the Ringold Formation and Hanford formation. This location corresponds to a depth of approximately 160 feet, and an elevation of about 390 feet above mean sea level.

Groundwater in the vicinity of the 400 Area moves in the unconfined aquifer to the southeast. Pumping of the production well 499-S1-8J at a depth of 360 to 390 feet within the 400 Area may result in drawdown in proximity to the well, but a noticeable cone of depression is not evident with the present water level data. Disposal of sanitary and process sewer effluent may have produced a small mound of groundwater beneath the 
DOE/RL-94-28, Rev. 0

$06 / 94$

400 Area Septic Systern

1 sewage lagoon and the 400 Area ponds. The height of the groundwater mound is

2 estimated to be one foot, based on water level data from wells in the vicinity of the $\mathbf{4 0 0}$

3 Area ponds.

Westinghouse Hanford Company

P.O. Box 1970

Richland, WA 99352

UST THE NAMTS AND ADDRESSES OF CONTRACTORSOR CONSULTANTS WHO PROVIDED INFORMATION AND CITE SOURCES OF INFORMATION BY TUTLEAND AUTHOR.

Kaiser Engineers Hanford

P.O. Box 888

Richland, WA 99352

Science Applications International Corp. 1845 Terminal Drive

Richland, WA 99352

Enserch Environmental Corp.

1201 Jadwin Avenue, Suite 202

Richland, WA 99352

Golder Associates Inc.

1933 Jadwin Avenue, Suite 125

Richland, WA 99352

Hart Crowser, Inc.

1201 Jadwin Avenue, Suite 204

Richland, WA 99352

References: $\quad$ Sources of information used for Section E are included in REFERENCES. 


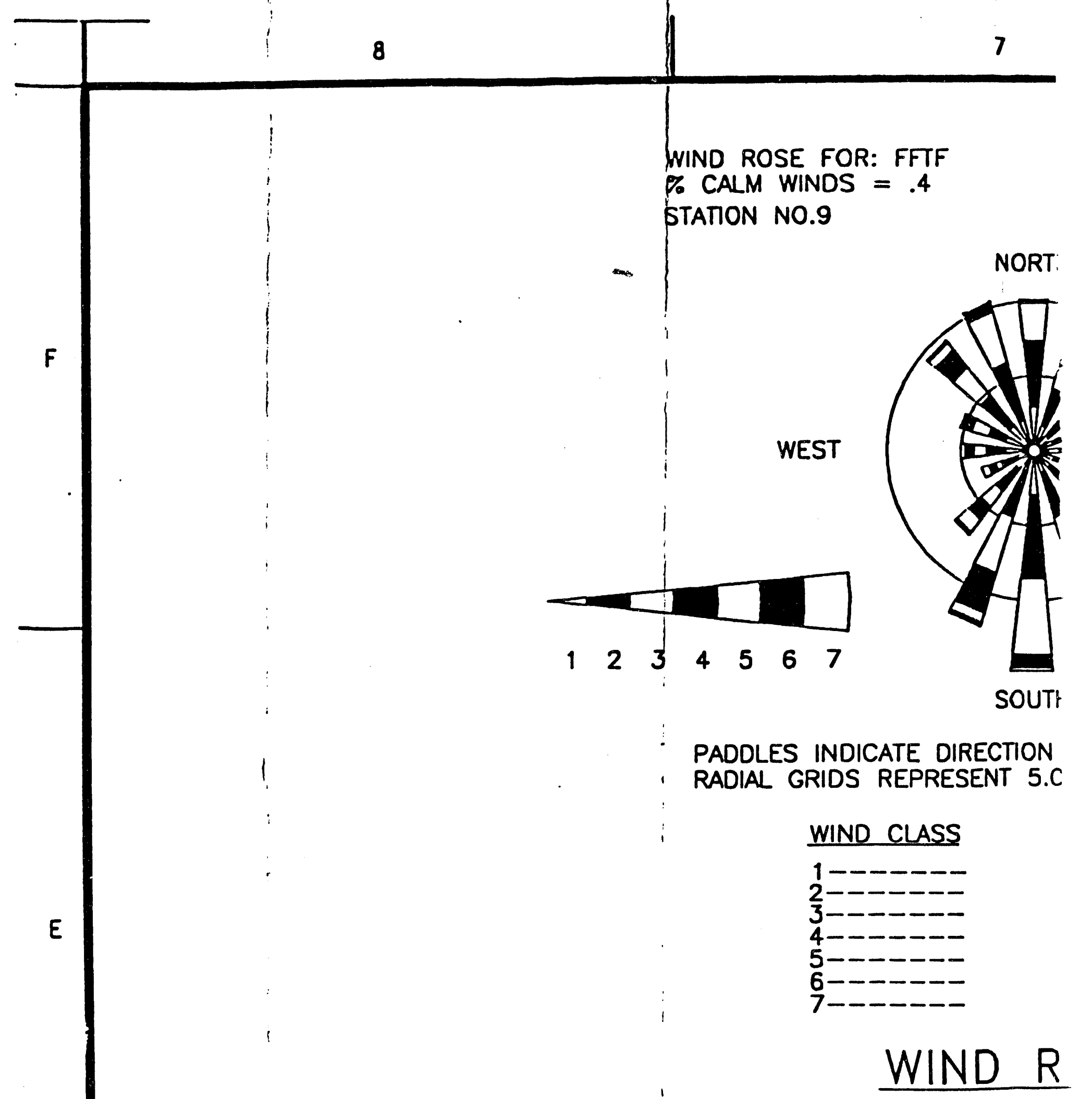


D ROSE FOR: FFTF

:ALM WINDS $=.4$

PERIOD COVERED

ION NO.9

$1 / 1 / 93-12 / 31 / 93$

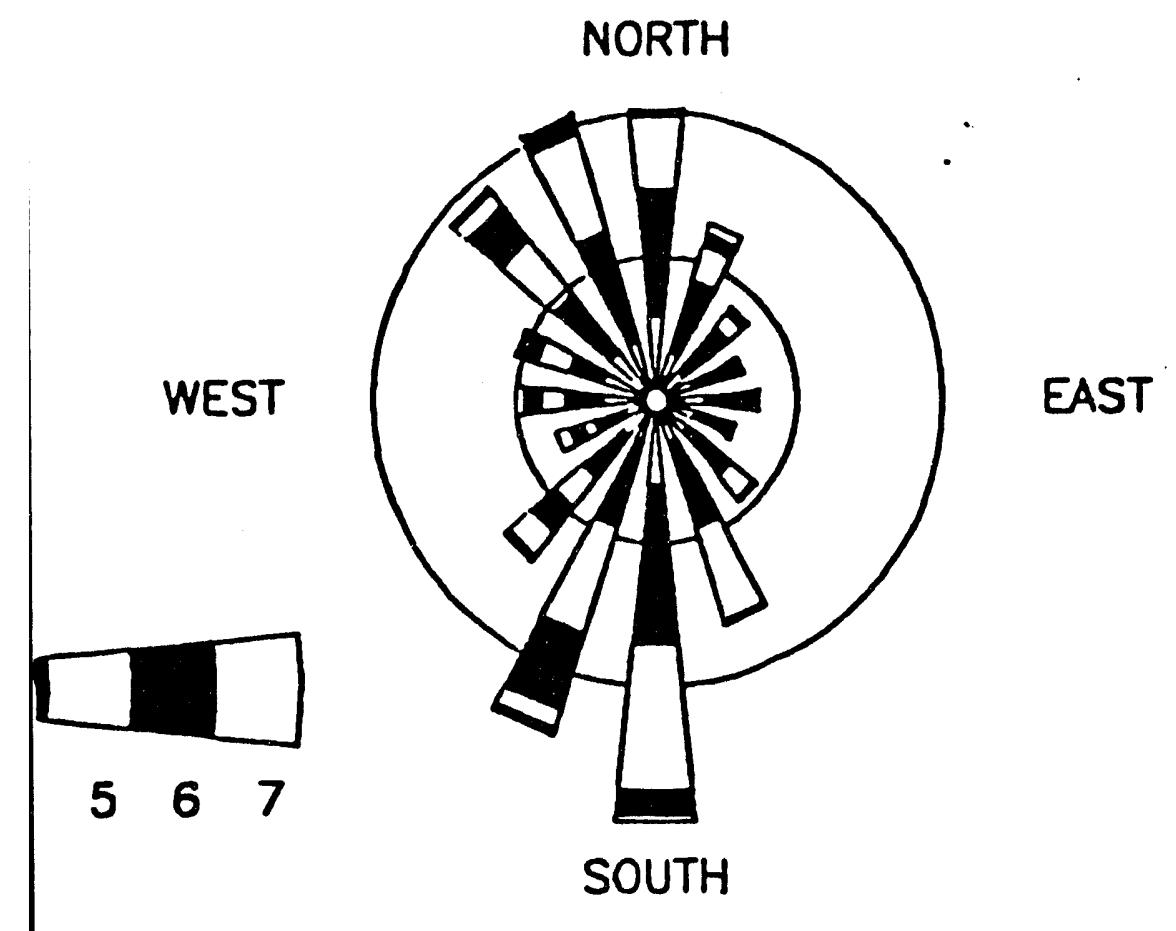

ADDLES INDICATE DIRECTION WIND IS COMING FROM.

ADIAL GRIDS REPRESENT $5.9 \%$ AND $10.0 \%$ OCCURRENCE.

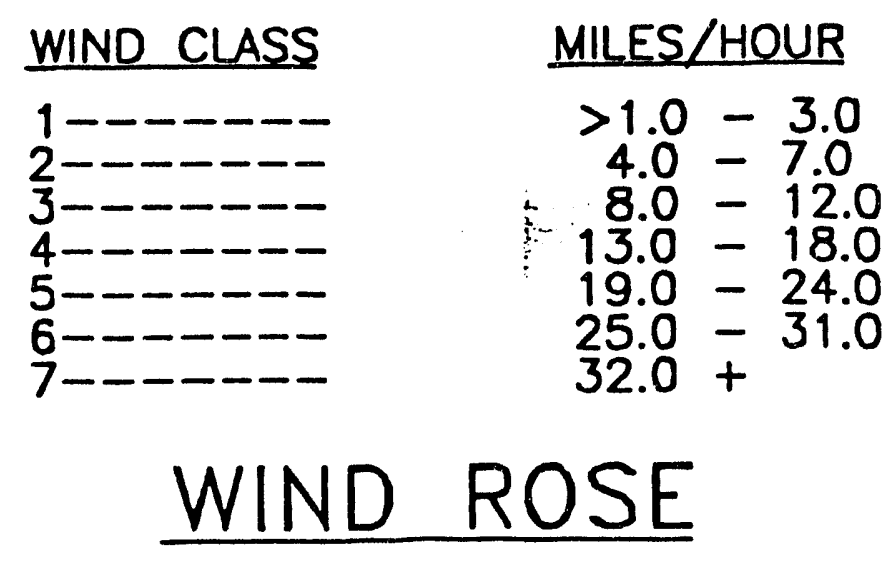




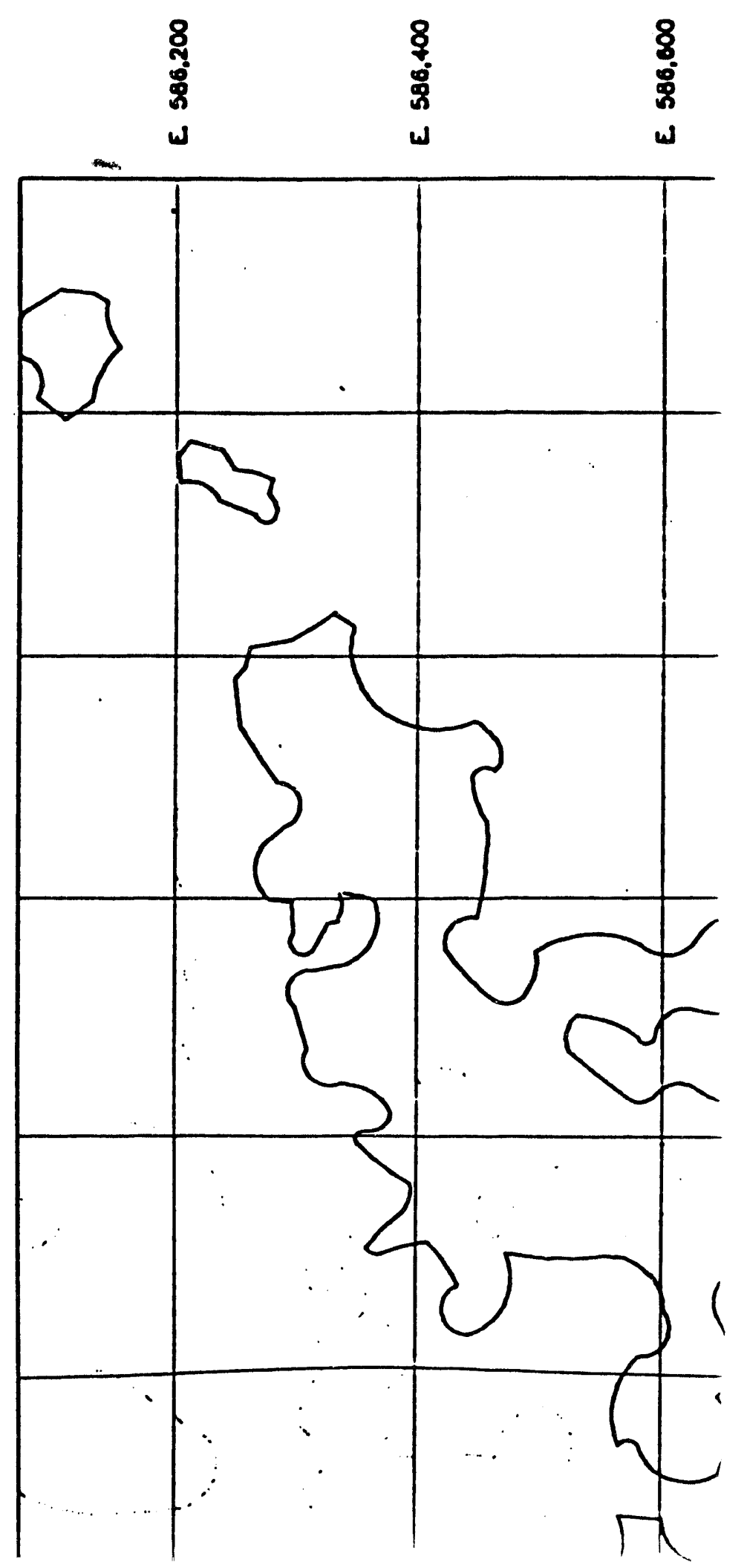




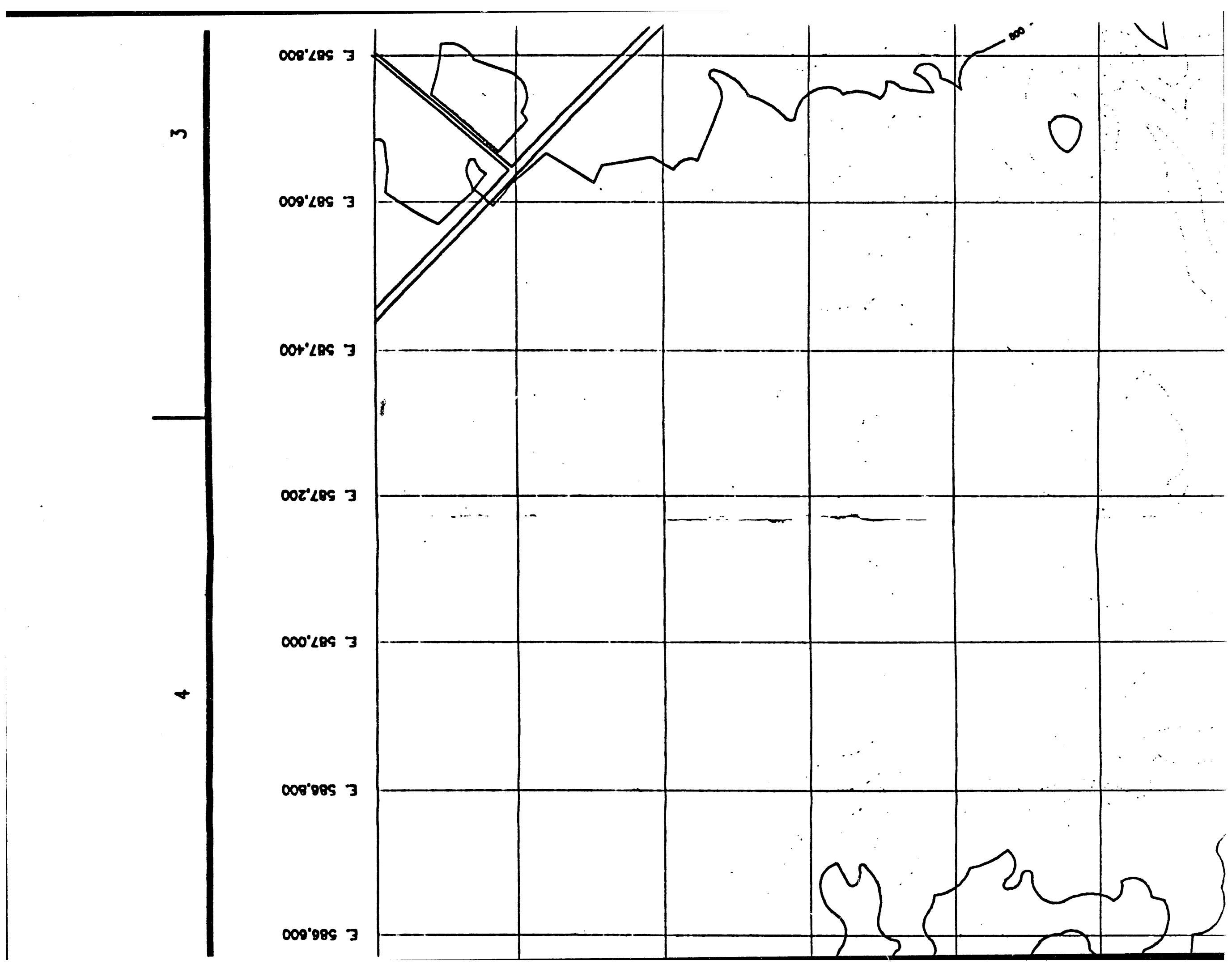




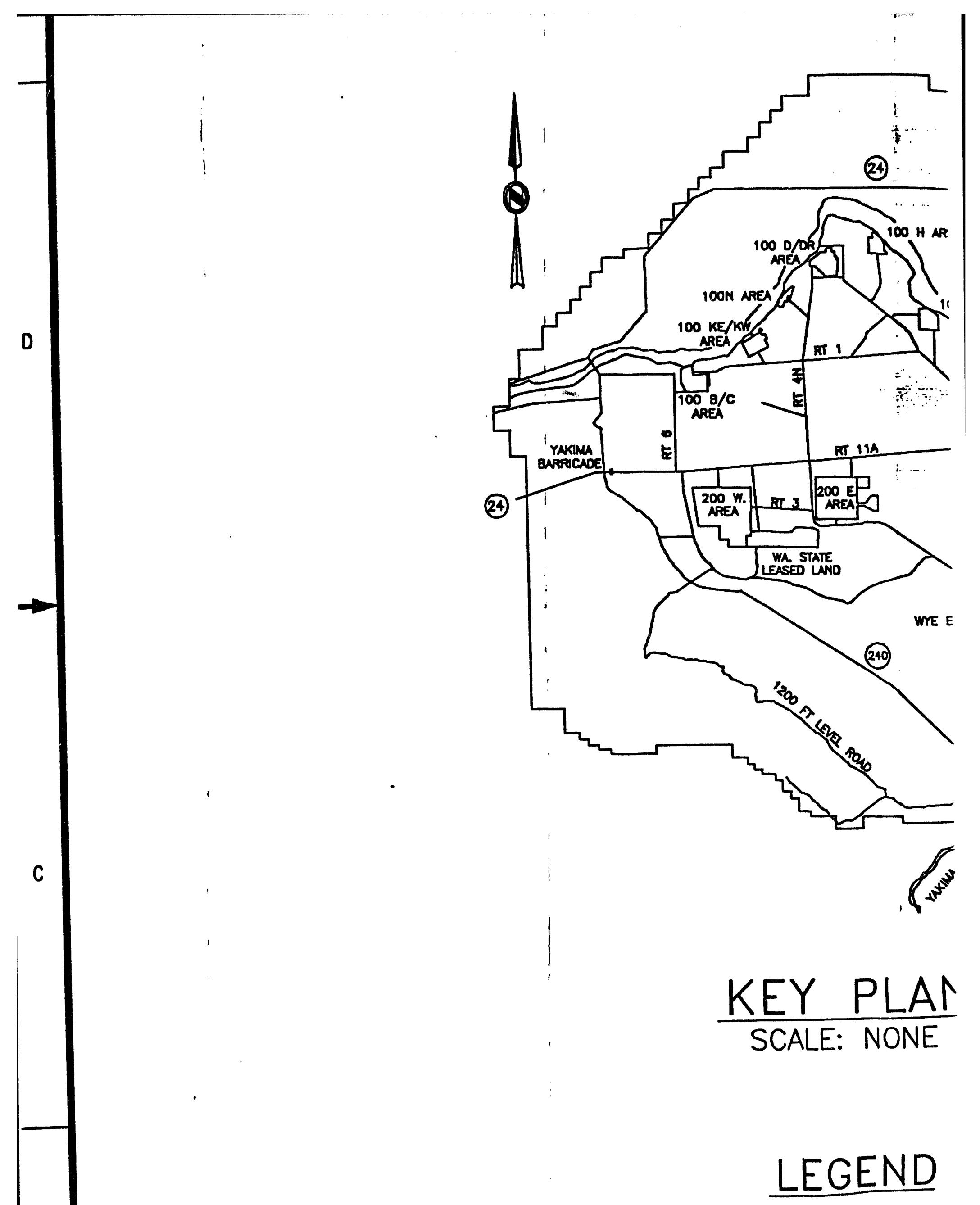




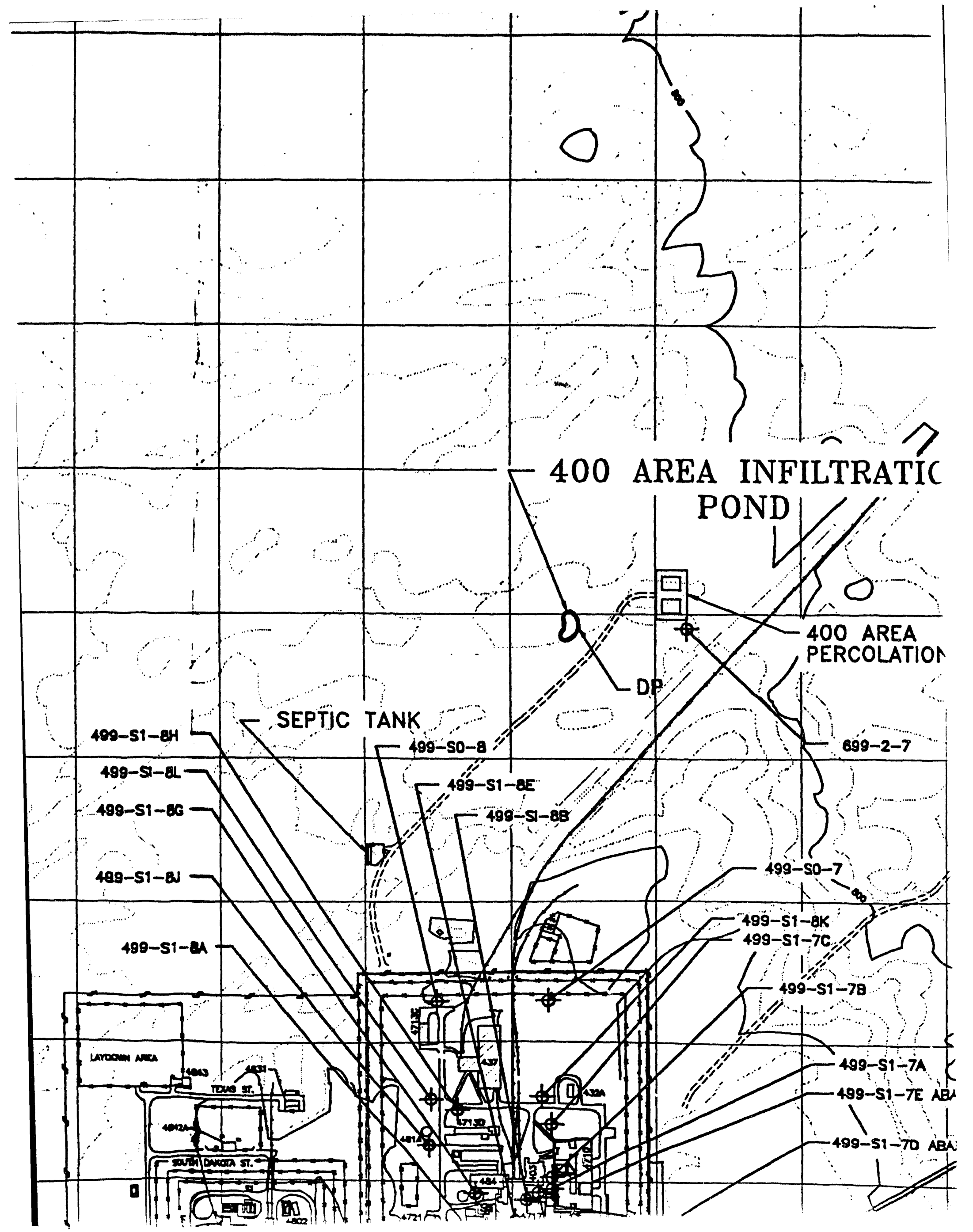




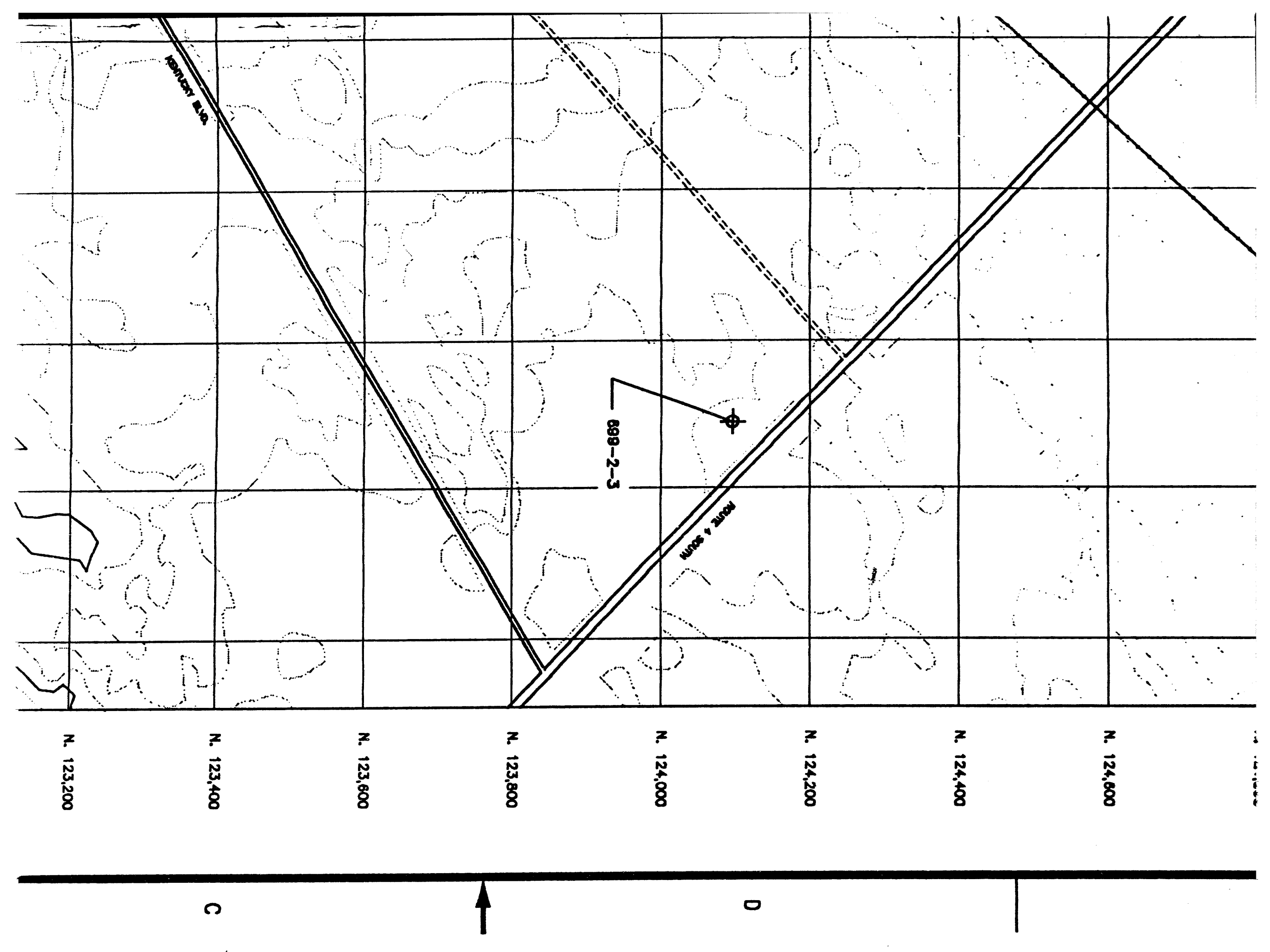




\section{LEGEND}

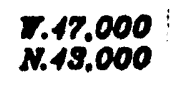

HANFORD PLANT COORDINATES (FEET)

E.576.250 ' WASHINGTON STATE COORDINATES

N.136,000 (METERS)

- Mar INDEX CONTOUR (METERS)

INTERMEDIATE CONTOUR

8

$=$ IMPROVED ROAD
$=$ UNIMPROVED ROAD

ニニニニ DIRT ROAD

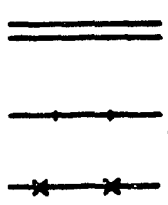

SIDEWALKS \PARKING LOTS

RALROADS

SECURITY,WARNING,MISC FENCES

POST \& CHANN

(CRIB,BURIAL GROUND FENCES)

PERIMETER FENCES

\section{GENERAL NOT}

1. THIS MAP WAS PRODUCED EY MAPPING SERVICES.

2. THE WASHINGTON COORDINATE SYSTEM OF 1983 SC $71 / 2$ MINUTE USGS QUADRANGLE MAP THAT WAS CORPORATION IN 1989 (DRAWING H-6-2436). TH BUTTE 1986 PROVISIONAL EDITION. CONTOUR INTER

7. ENTIRE AREA SHOWN IS WITHIN TOWNSHIP 11 NOR: 


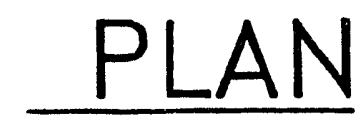

三: NONE

$\underline{\text { GEND }}$

ES

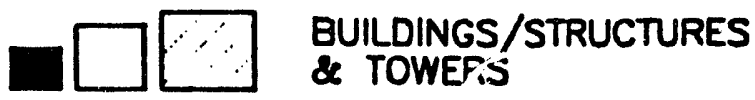

242-A BUILDING NUMBER

$\square$ MOBILE OFFICES

$N-27$

ф WELI

D ABANDONED WELL

O TANKS

216-A-42 CRIB

218-E-10 BURIAL GROUND

DP DISCHARGE POINT

S

IAL NOTES:

NG SERVICES.

$M$ OF 1983 SOUTH ZONE WAS ADDED TO THE IAP THAT WAS DIGITIZED BY AUSTIN MCDANIEI 6-2436). THE BASE MAP WAS THE GABLE IONTOUR INTERVAL 10 FEET.

ISHIP 11 NORTH AND RANGES 27 AND 28 EAST.

\section{SITE PL}

SCALE: $1: 60 C$
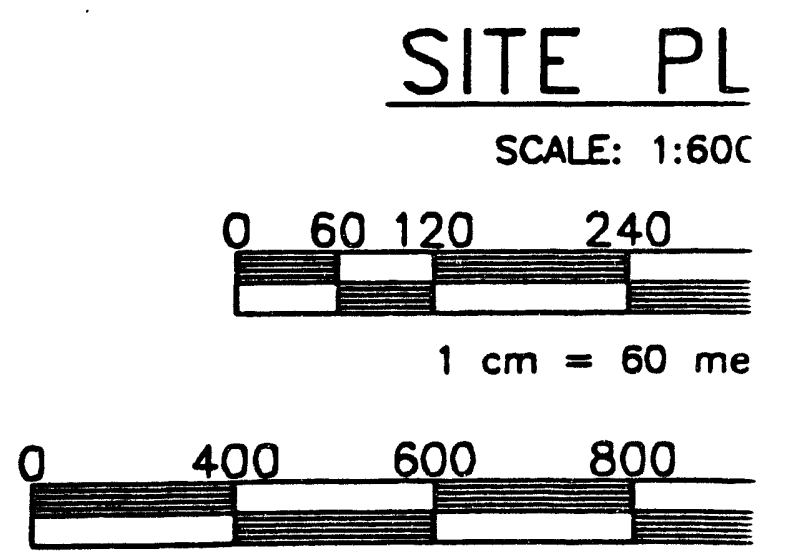


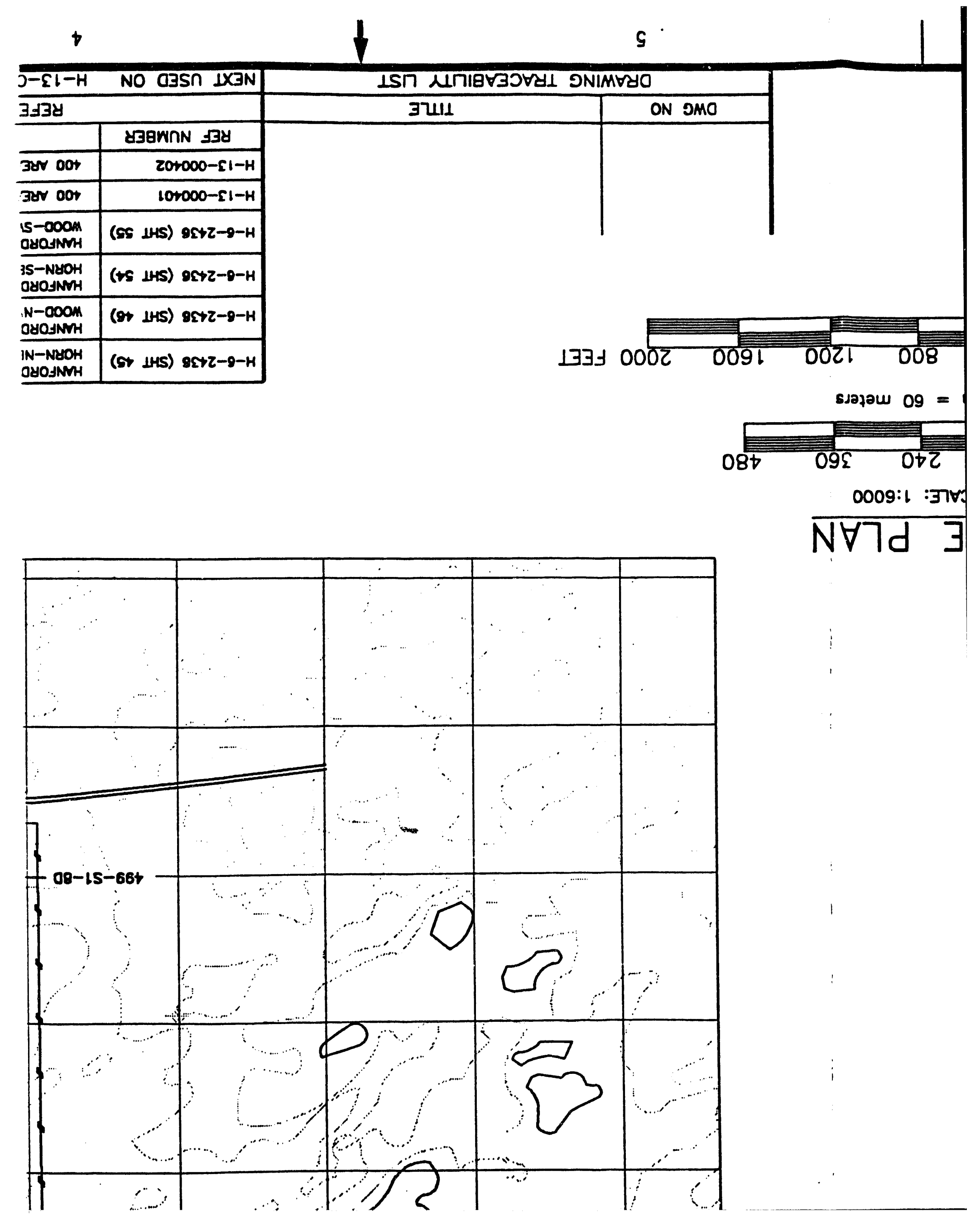




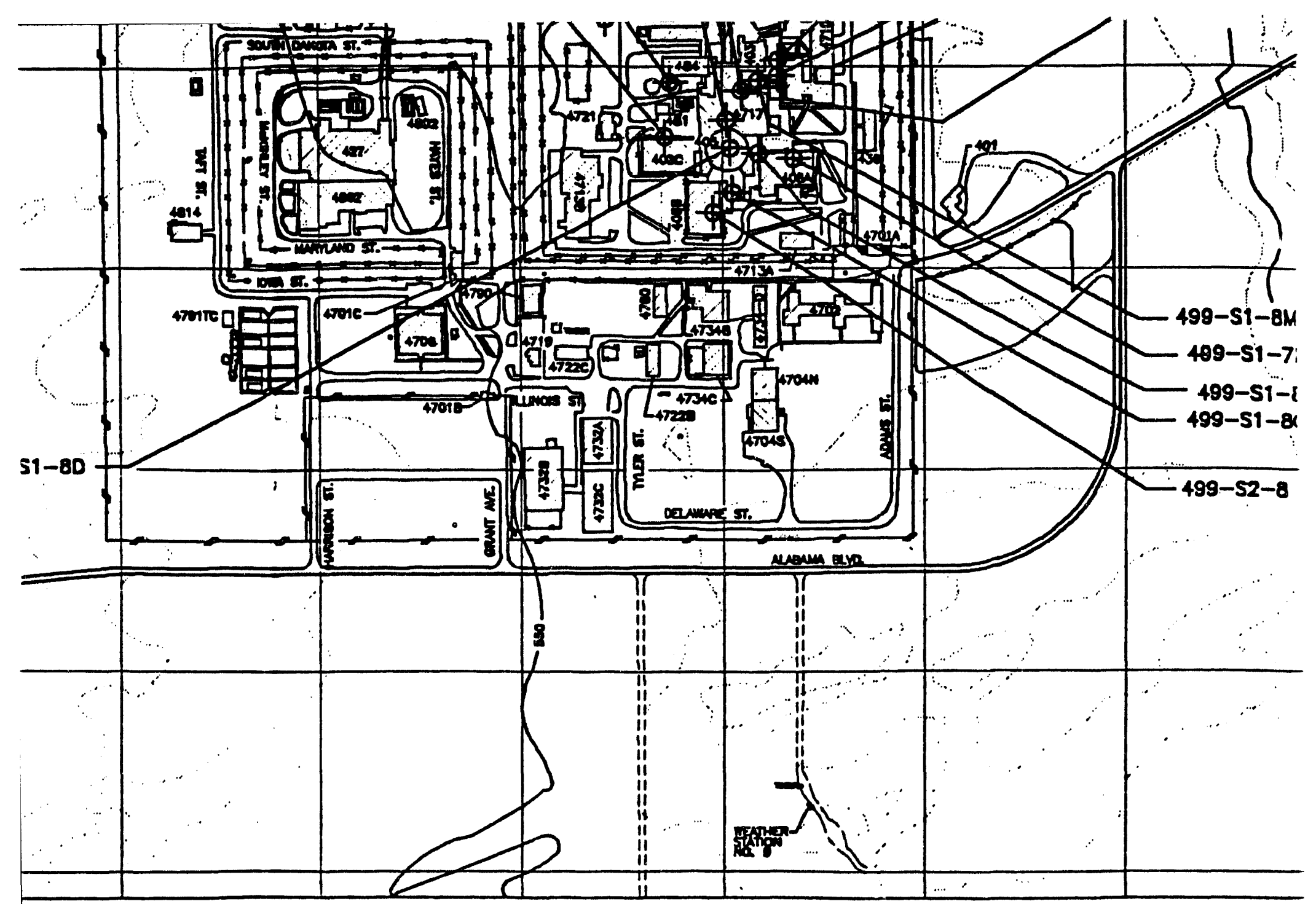

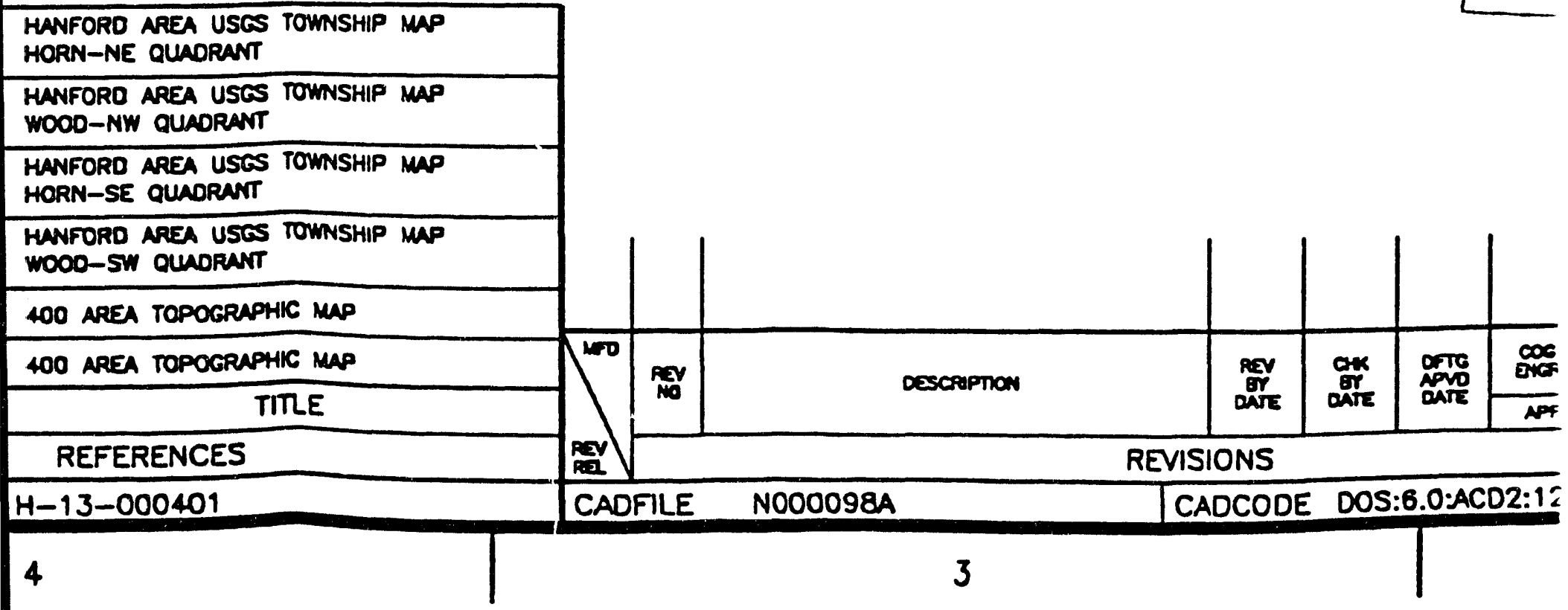




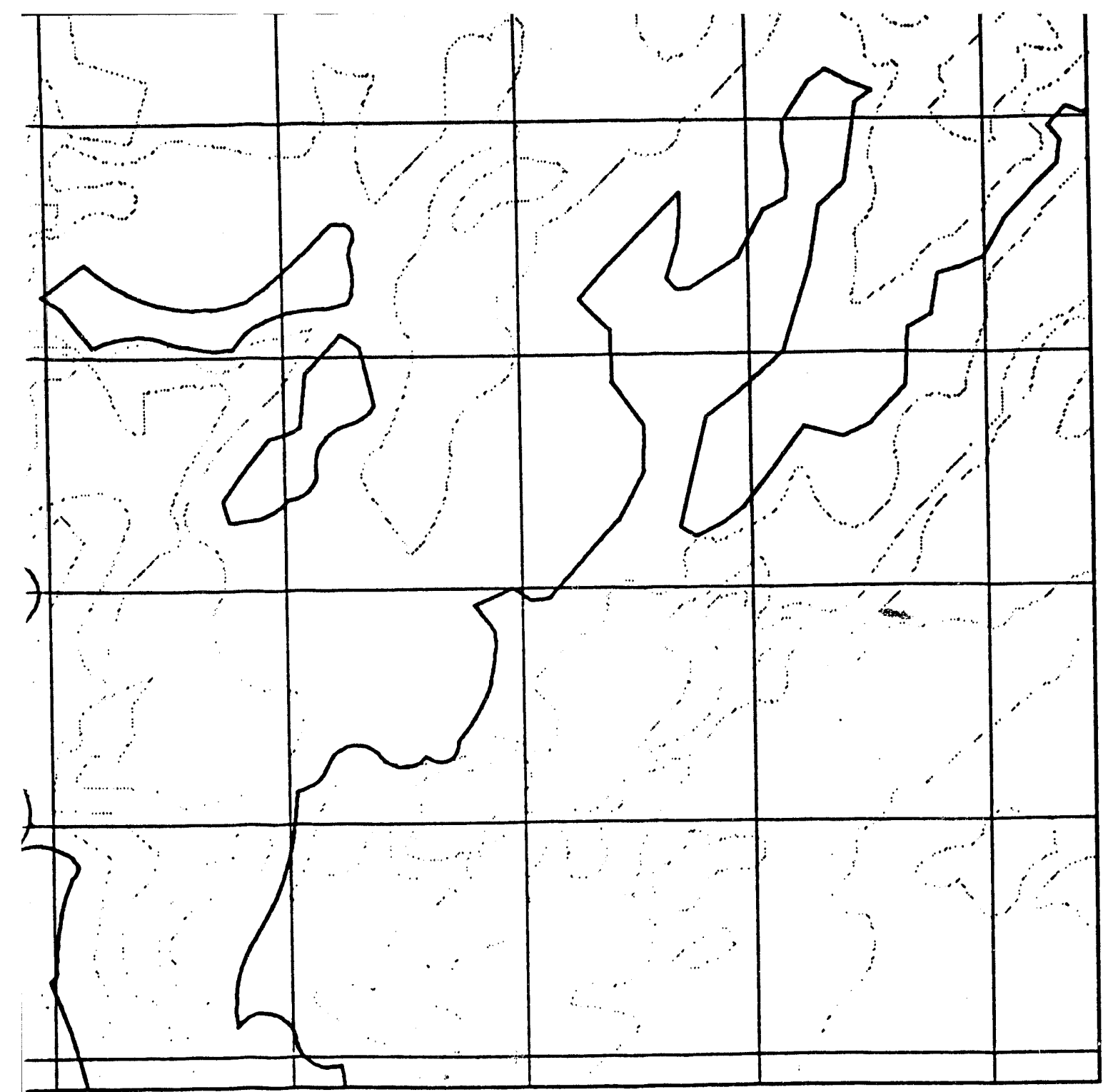

N. 123,200

N. 123,000

0

N. 122,800

N. 122,600

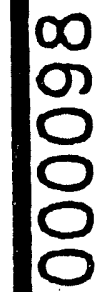

N. 122,400

THIS MAP IS TO BE USED FOR REFERENCE PURPOSES ONLY. DO NOT USE THIS MAP FOR CONSTRUCTION PURPOSES.

$$
\begin{aligned}
& \text {. } \\
& \text { (a) }
\end{aligned}
$$

RAw RAFAEL TORRES 4-26-94

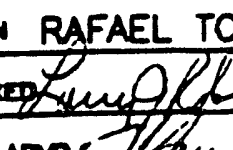

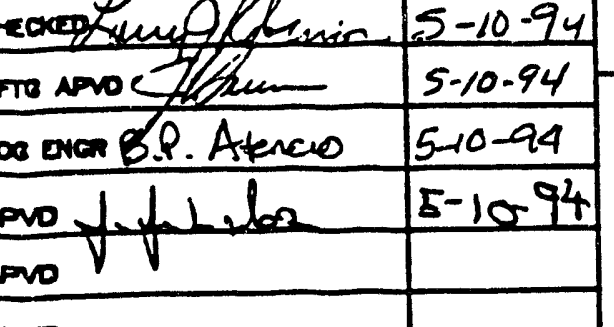

h

U.S. DEPARTMENT OF ENERGY
DOE Field Office. Richland
Westinghouse Hanford Compony

400 AREA

\section{INFILTRATION POND}

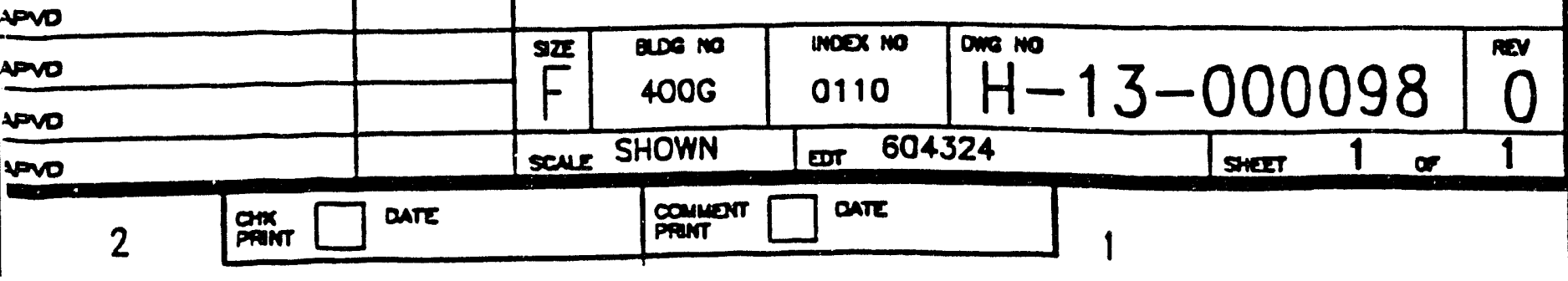




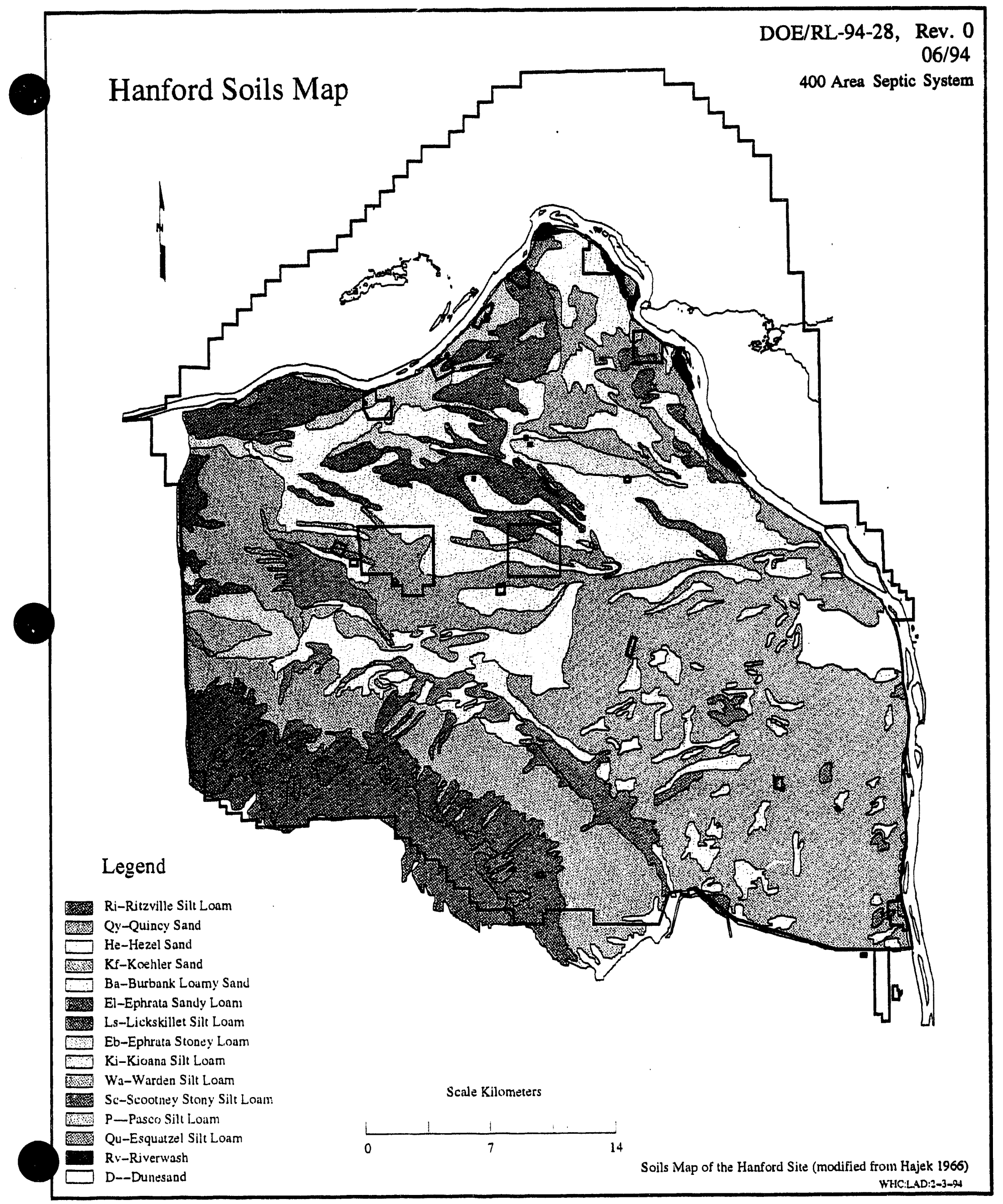

Figure E-1. Hanford Soils Map. 


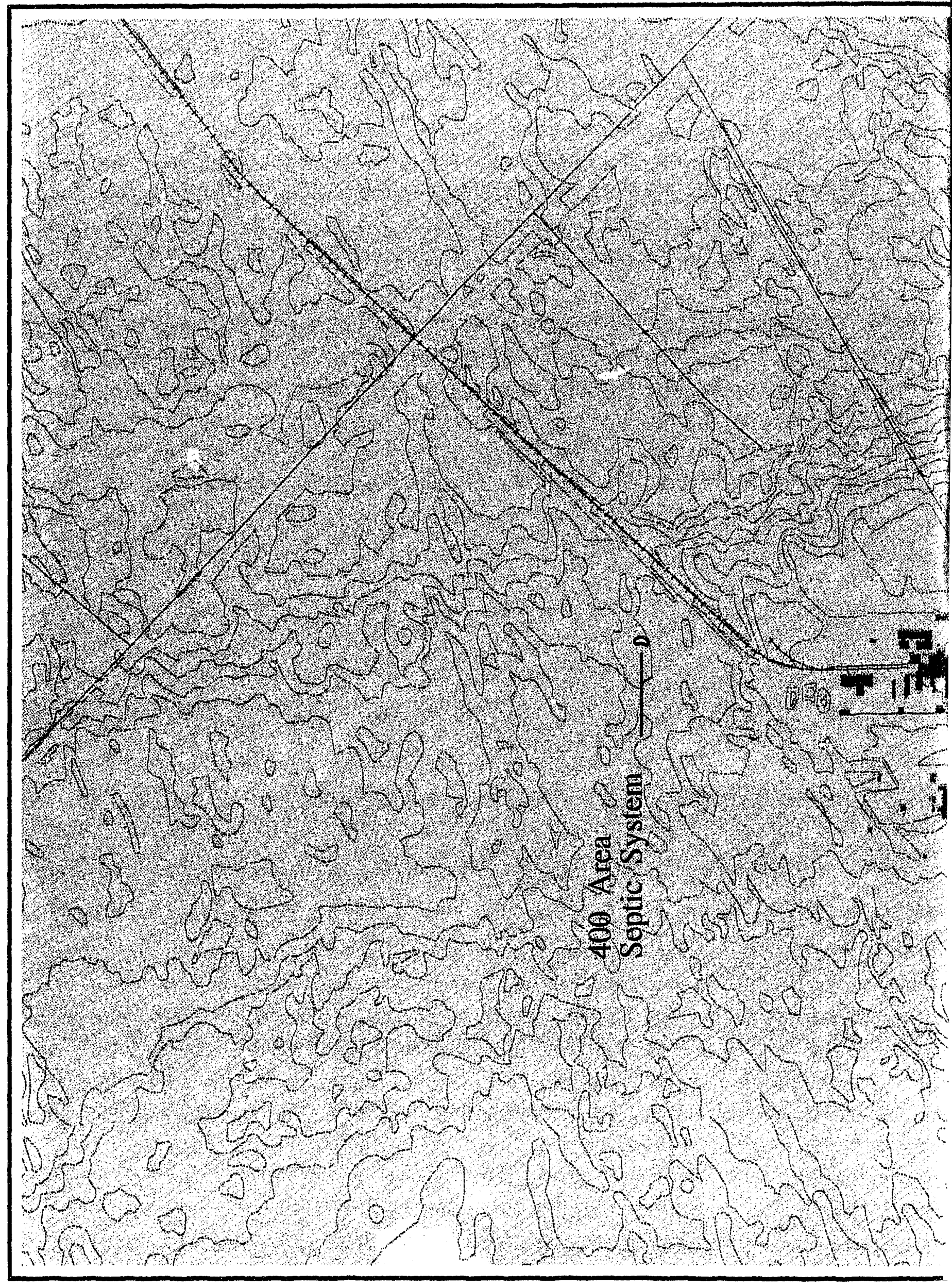




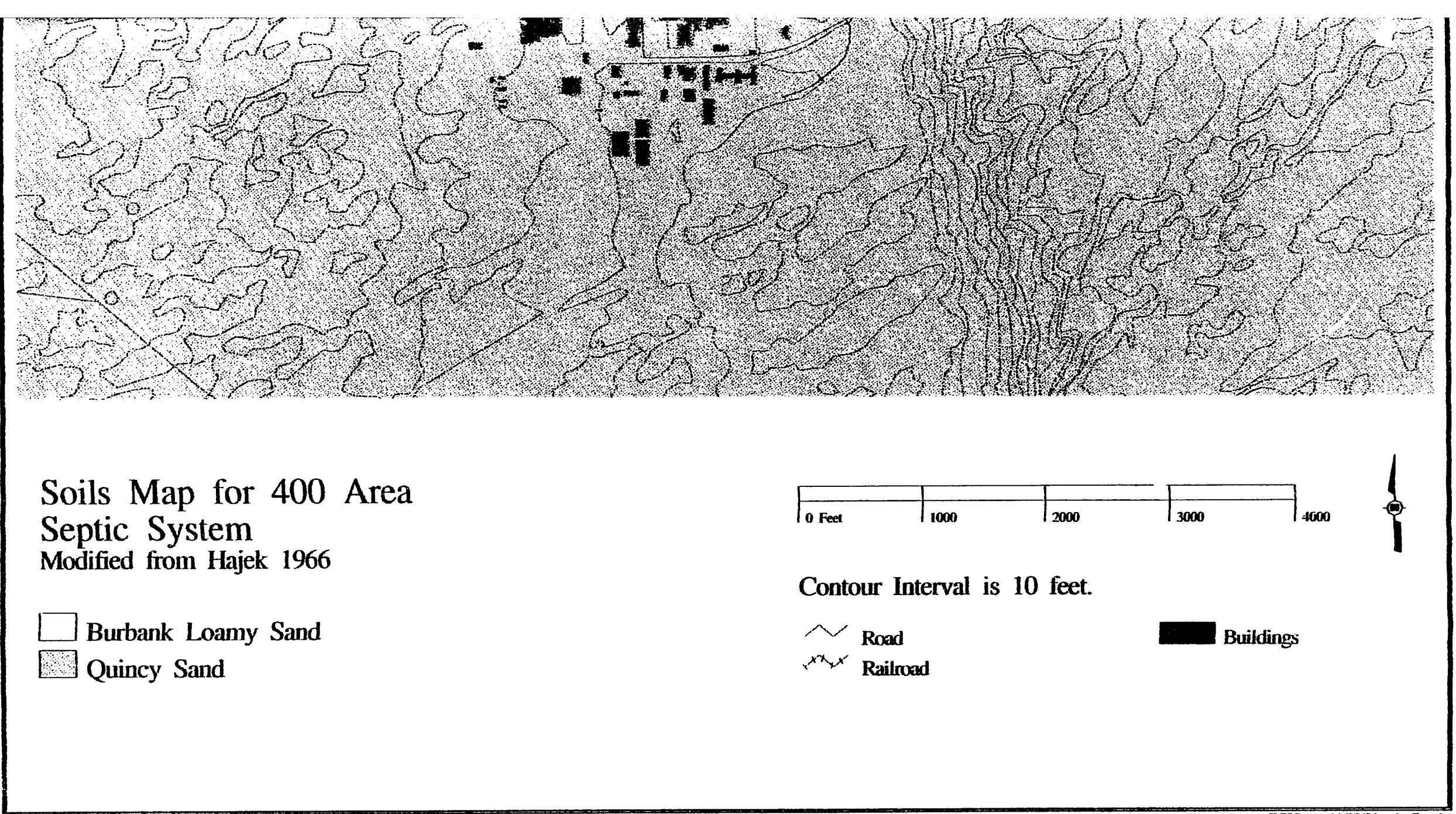

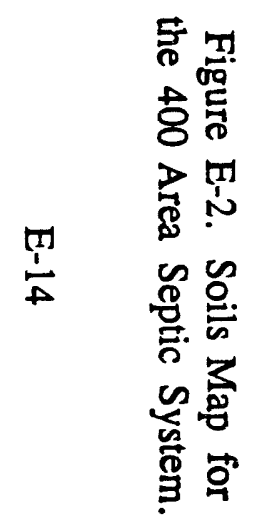

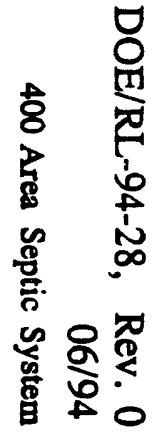




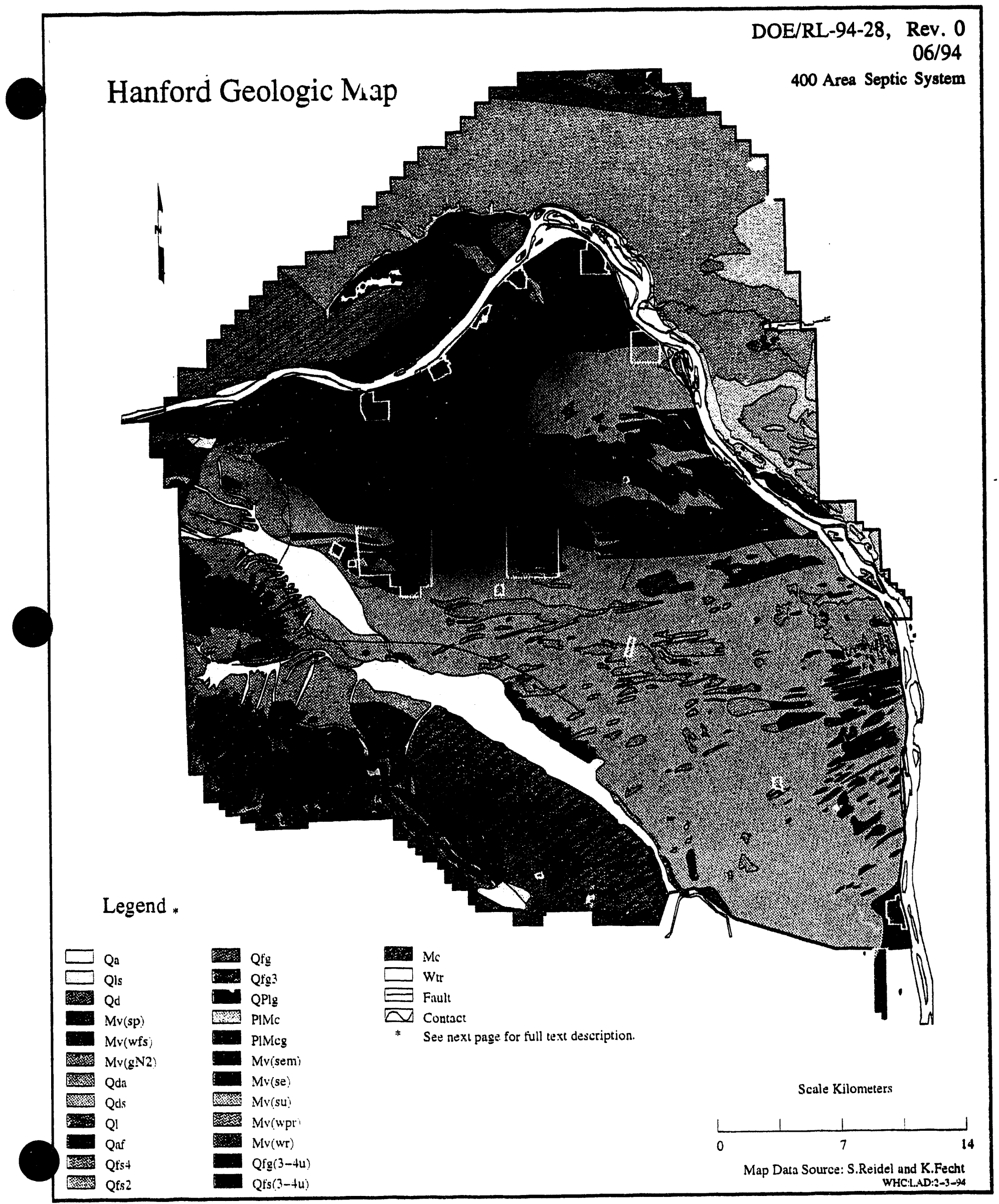

Figure E-3. Hanford Geologic Map. 


\section{Legend}

Qa-Alluvium (Holo.-Pleis.)

Qls-Mass-wasting deposits (Holo.-Pleis.)

Qd-Dune sand (Holocene)

Mv(sp)-Saddle Mt Basalt, Pomona Mbr (M. Mio.)

- Mv(wfs)-Wanapum Basalt, Frenchman Spr. Mbr (M. Mio.)

$\mathrm{Mv}(\mathrm{gN} 2)-\mathrm{Grande}$ Ronde Basalt, U. flow-normal pol. (M. Mio.)

Qda-Dune sand, active (Holocene)

Qds-Dune sand, stabilized (Holocene)

Q1-Loess (Holocene to Pleistocene)

Qaf-Alluvial fans (Holo.-Pleis.)

Qts4-Outburst flood dep.(Pleis.), silt \& sand, youngest

Qfs2-Outburst flood dep.(Pleis.), silt \& sand, 2nd oldest

Qfg-Outburst flood dep.(Pleis.), gravels, undiv.

Qfg3-Outburst flood dep.(Pleis.), gravels, 2nd youngest

QPlg-Gravel (Pleistocene to Pliocene)

PIMc-Ringold Fm., Continental sed. (Plio.-Mio.)

PIMcg-Ringold Fm., Conglomerate (Plio.-Mio.)

Mv(sem)-Saddle Mt Basalt, Elephant Mt Mbr (U. Mio.)

Dv(se)-Saddle Mt Basalt, Esquatzel Mbr (M. Mio.)

$\mathrm{Mv}(\mathrm{su})$-Saddle Mt Basalt, Umatilla Mbr (M. Mio.)

$\mathrm{Mv}$ (wpr)-Wanapum Basalt, Priest Rapids Mbr (M. Mio.)

$\mathrm{Mv}(\mathrm{wr})$-Wanapum Basalt. Roza Mbr (M. Mio)

Qfg(3-4u)-Outburst flood dep., gravels, undif.

Qfs(3-4u)-Outburst flood dep., sands, undif.

Mc-Cont. sed. dep.-interbeds in Columbia R. Basalt

$\square$ WTR-Water

$\equiv$ FAULT-Fault

$\triangle$ CONTACT-Contact between geologic units

Figure E-4. Legend for Hanford Geologic Map. 
DOE/RL-94-28, Rev. 0 06/94

400 Area Septic Systom

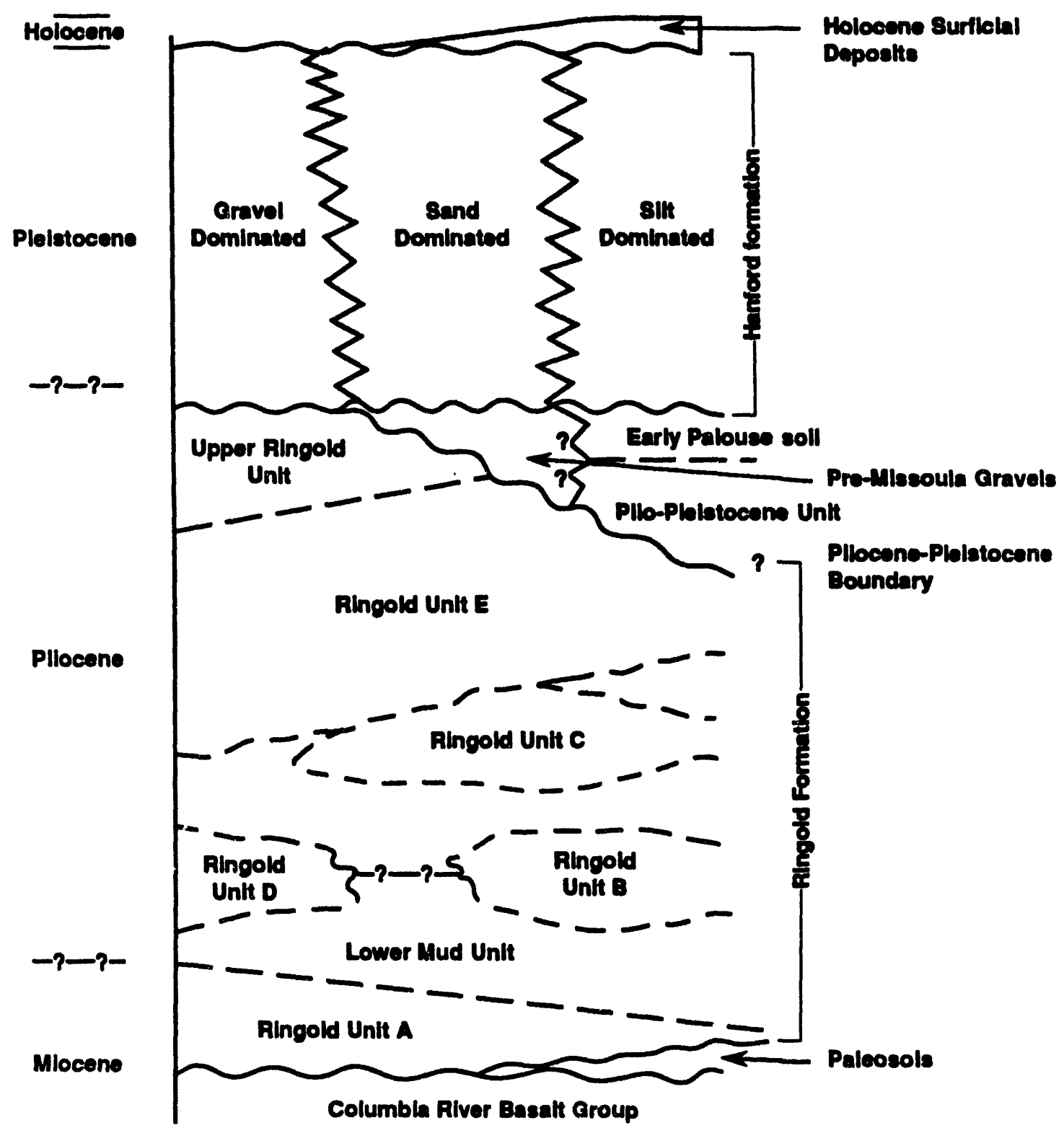

H9210018.1A

Figure E-5. Regional Stratigraphic Column. 


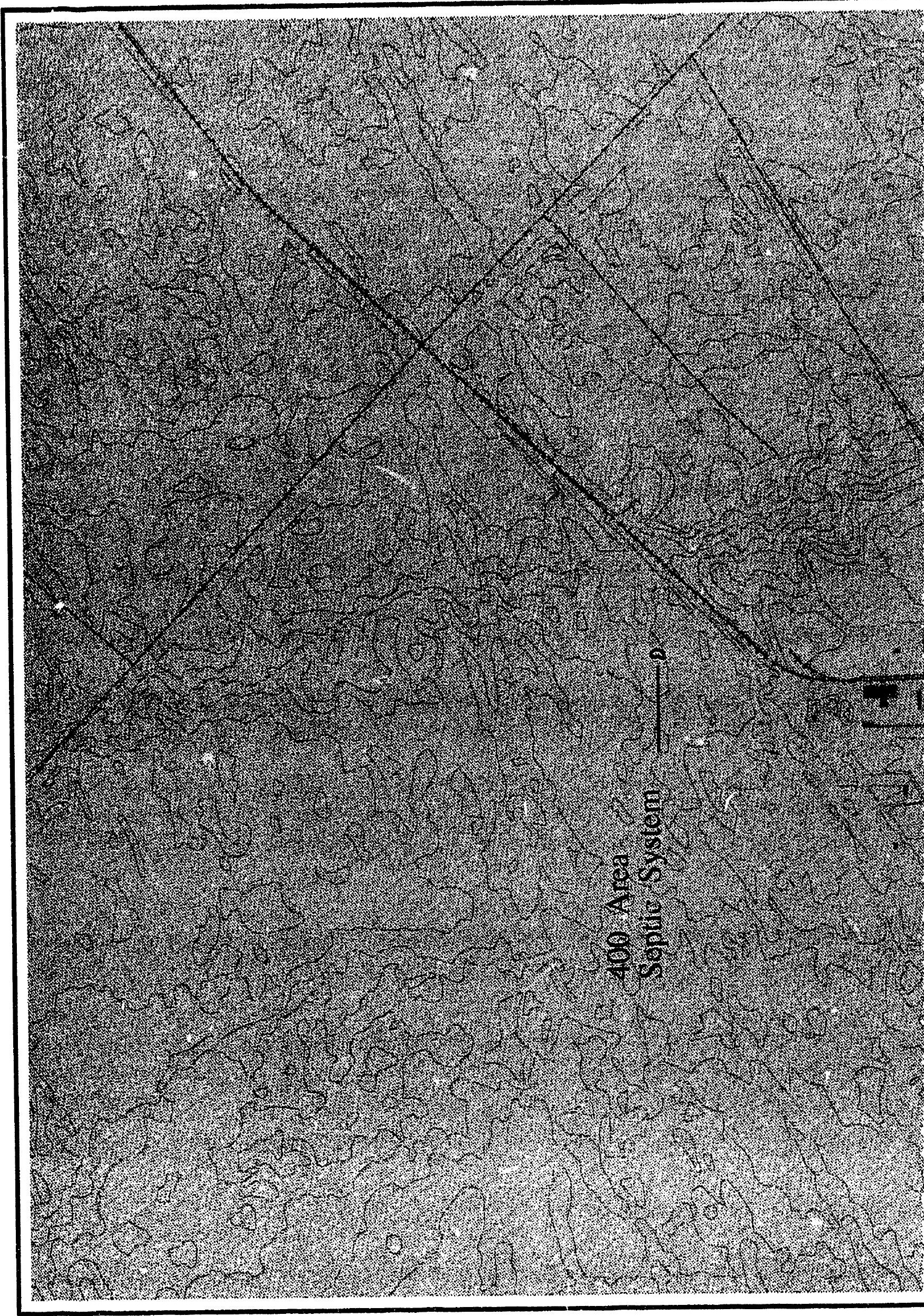




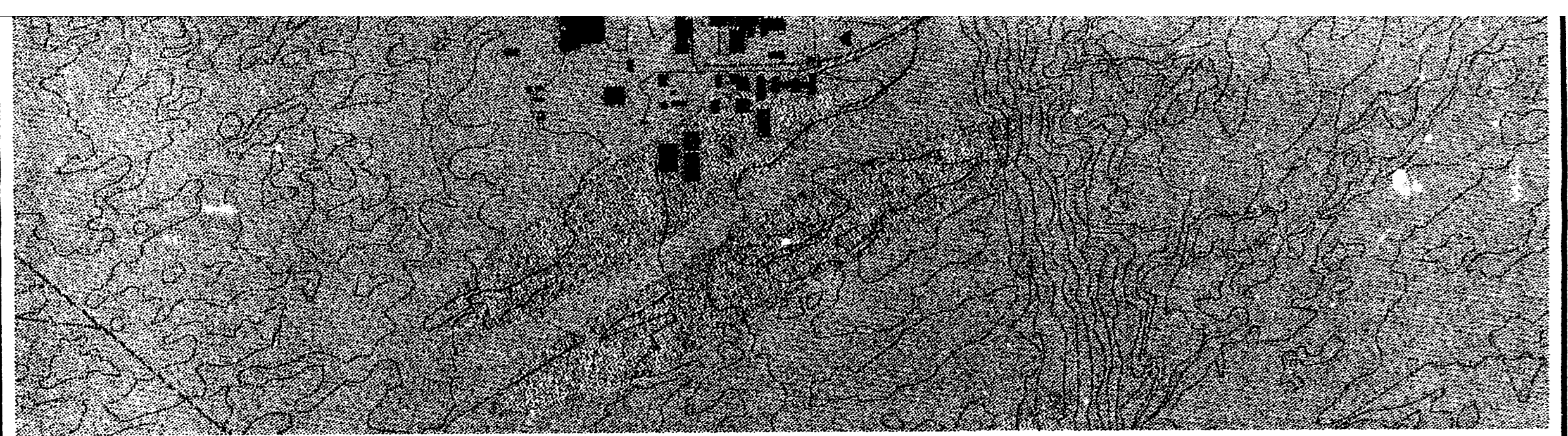

Geology Map for 400 Area Septic System

Map source: S. Reidel and K. Fecht

風 Qds

Q:

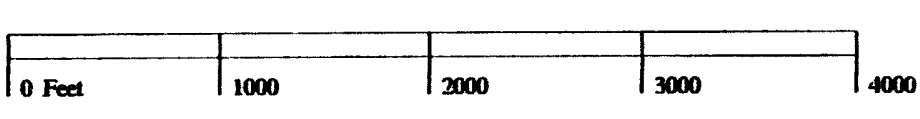

Contour Interval is 10 feet.

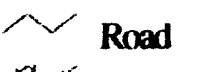

Nx Railroad

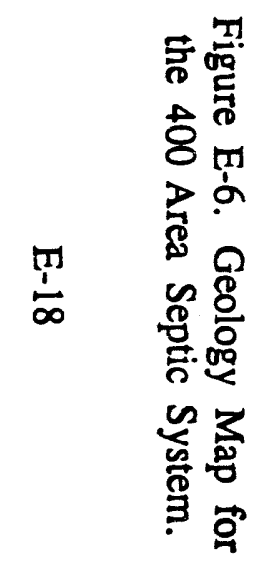



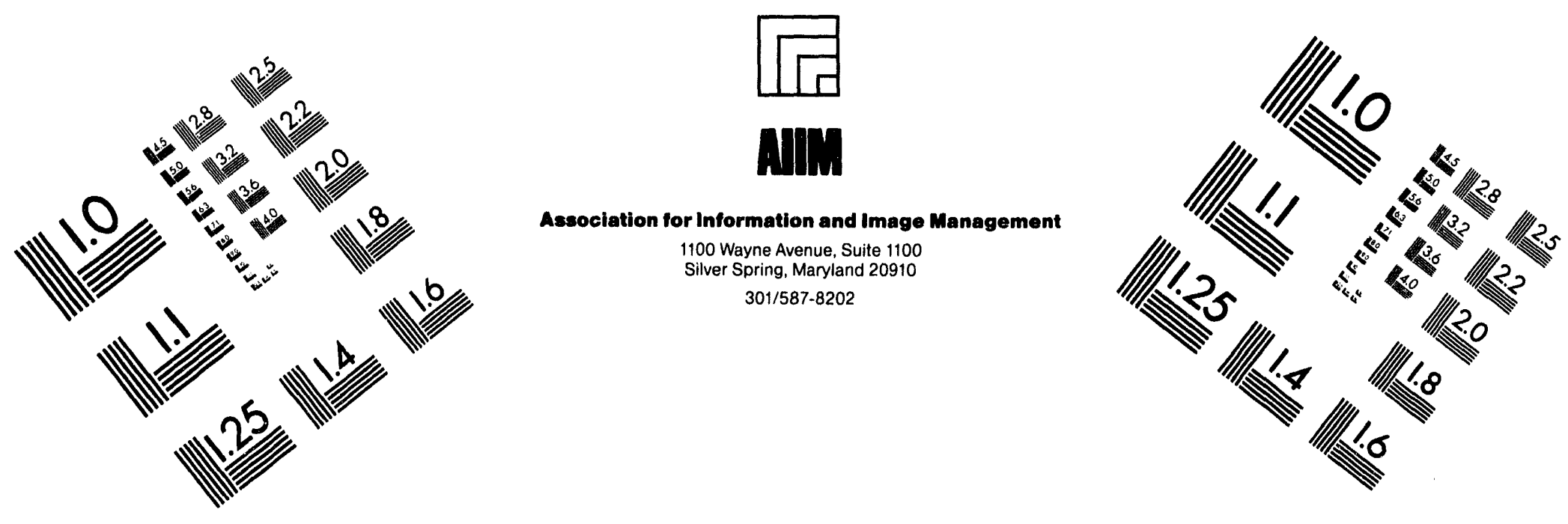

\section{Centimeter}

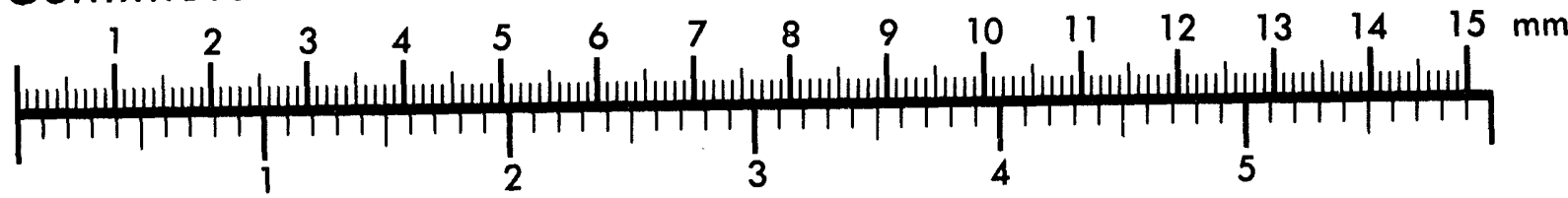

Inches
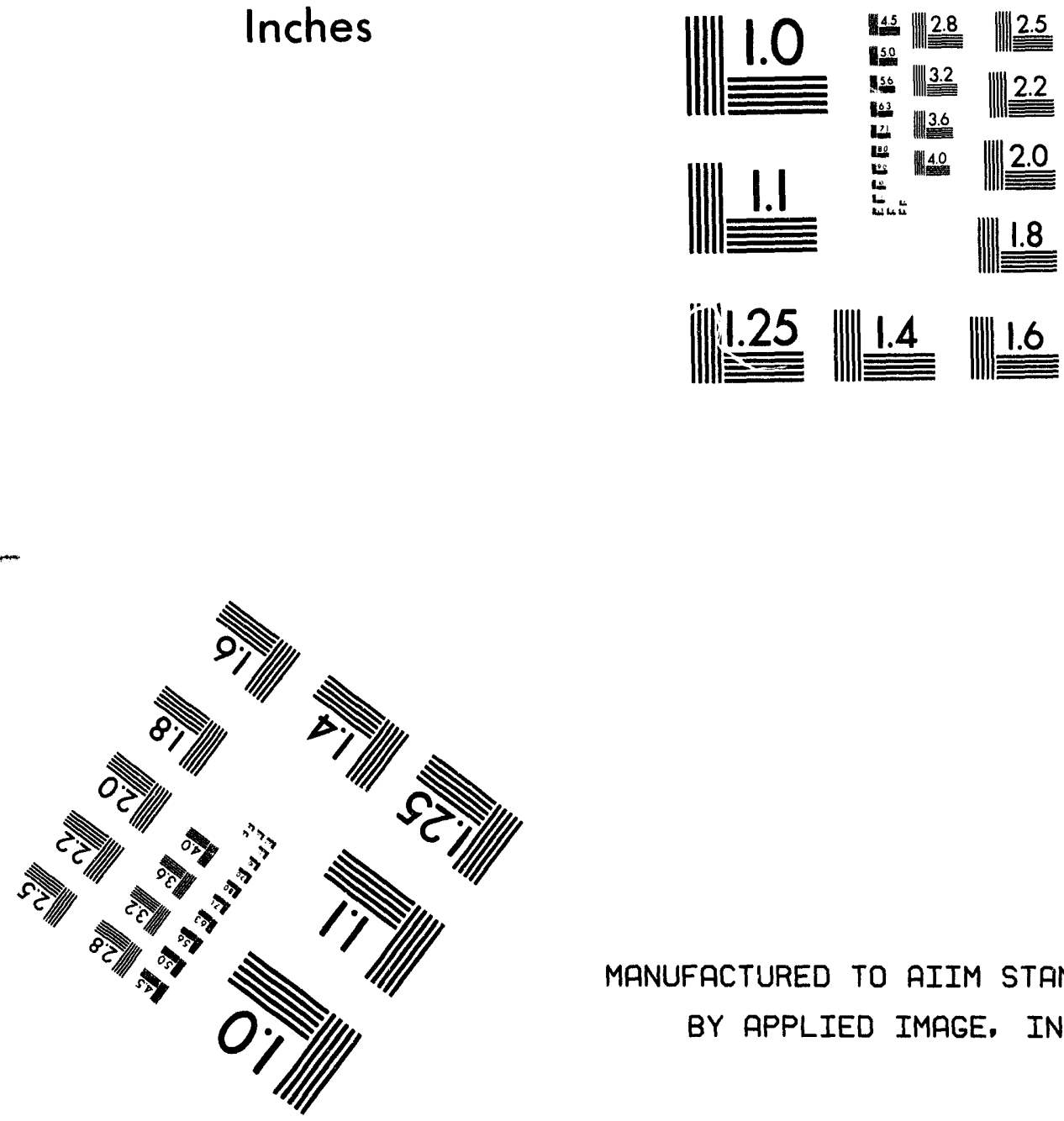

MANUFACTURED TO AIIM STANDARDS

BY APPLIED IMAGE, INC.

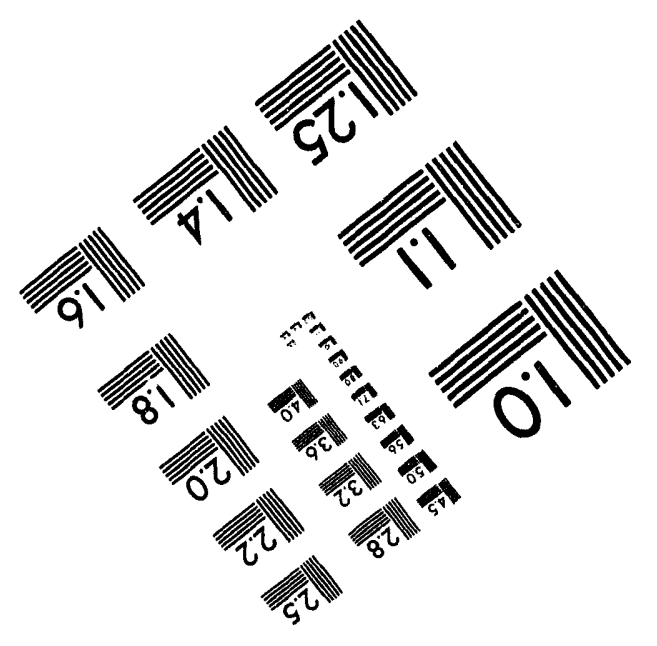



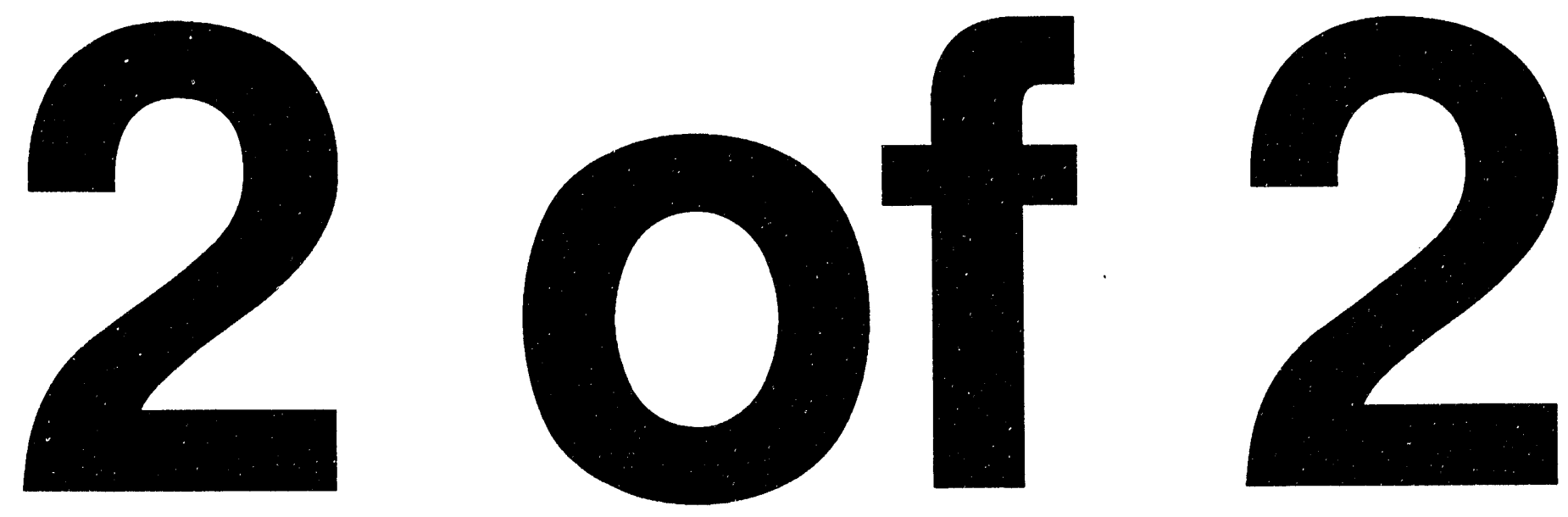
DOE/RL-94-28, Rev. 0 06/94

400 Area Septic System
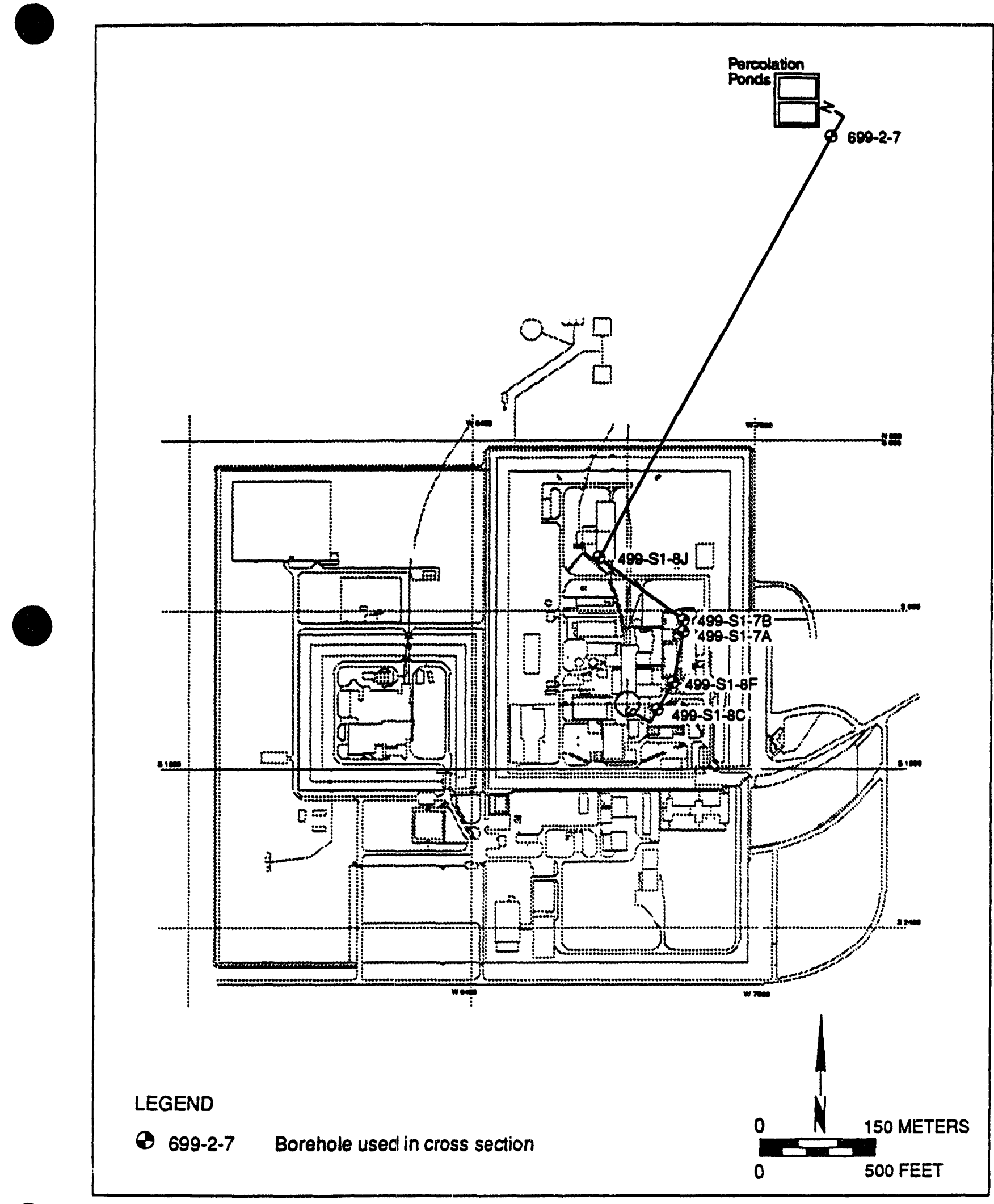

913 1728R/24243/10-16-92

Figure E-7. Line of Cross-Section for the 400 Area. 

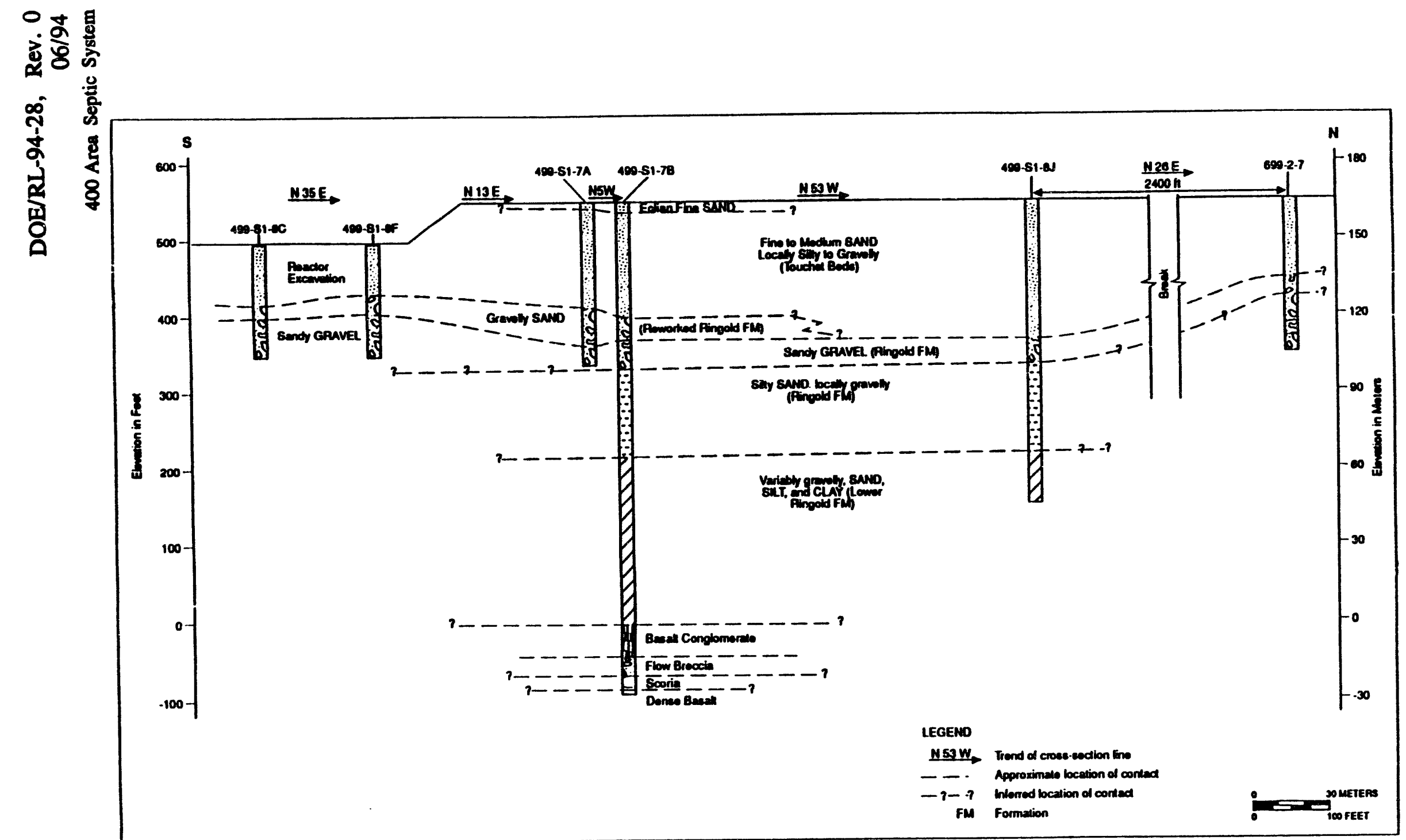


\section{Hanford Water Tablo Map}

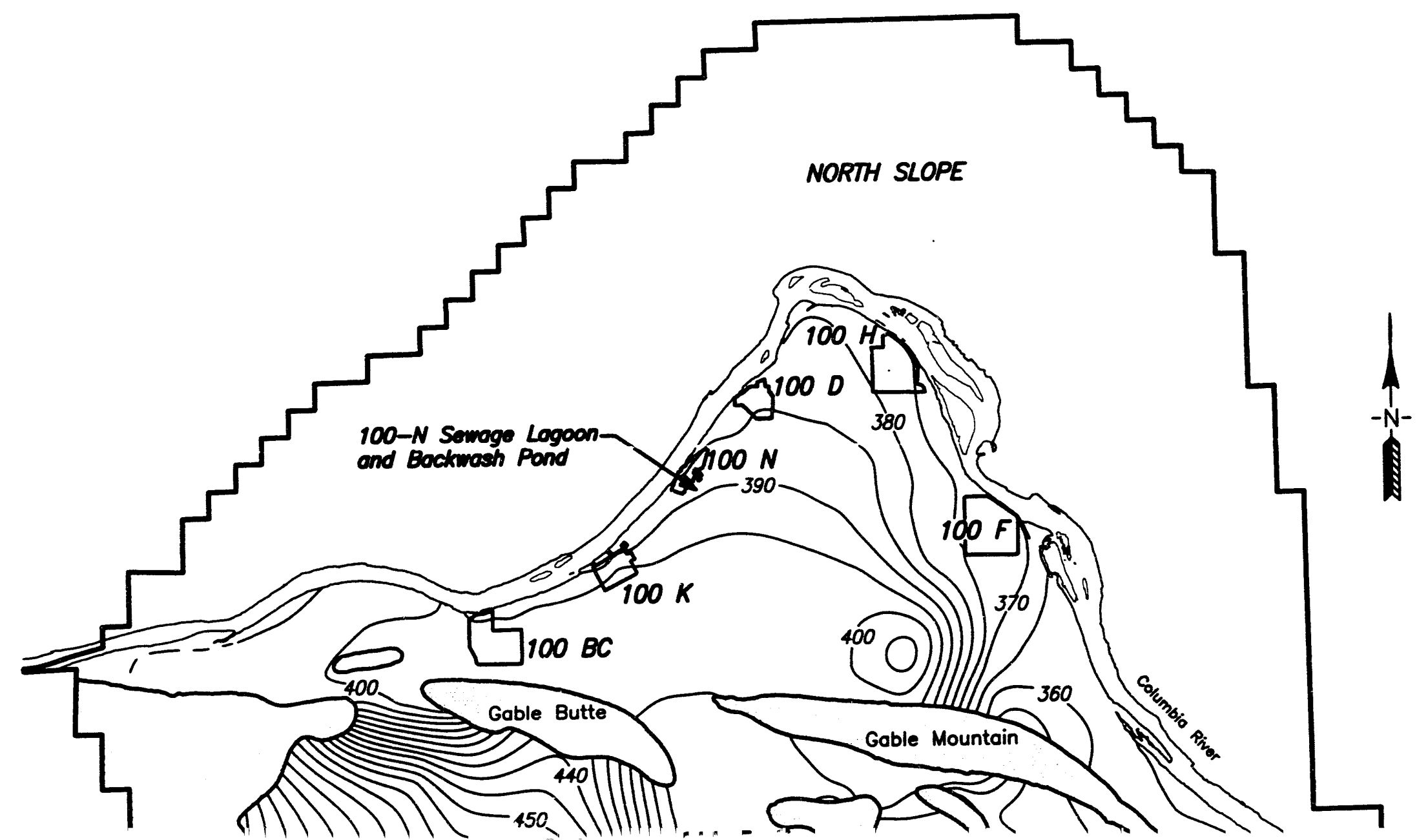


DOE/RL-94-28, Rev. 0

06/94

400 Area Septic System

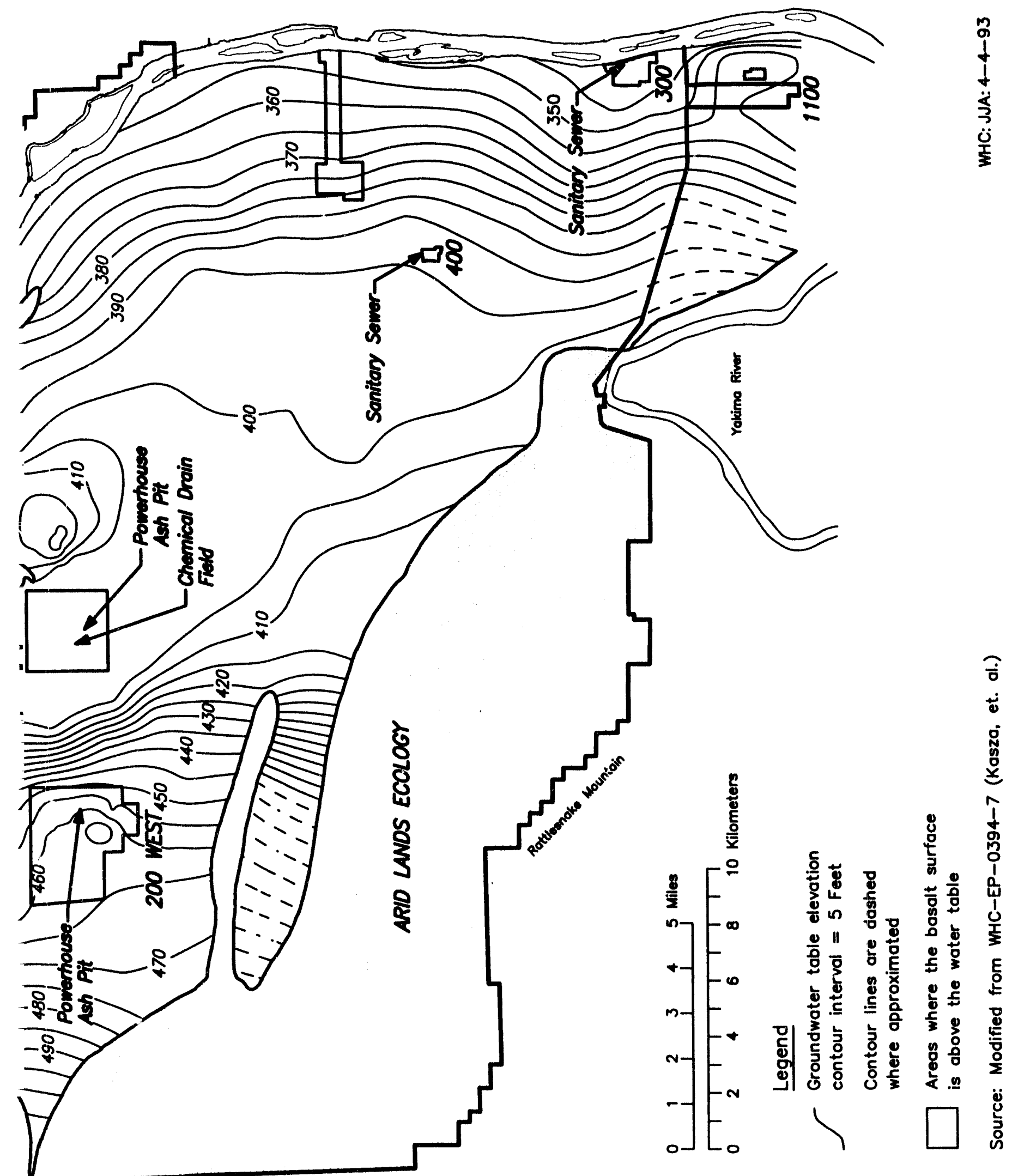

Figure E-9. Hanford Water Table Map. 

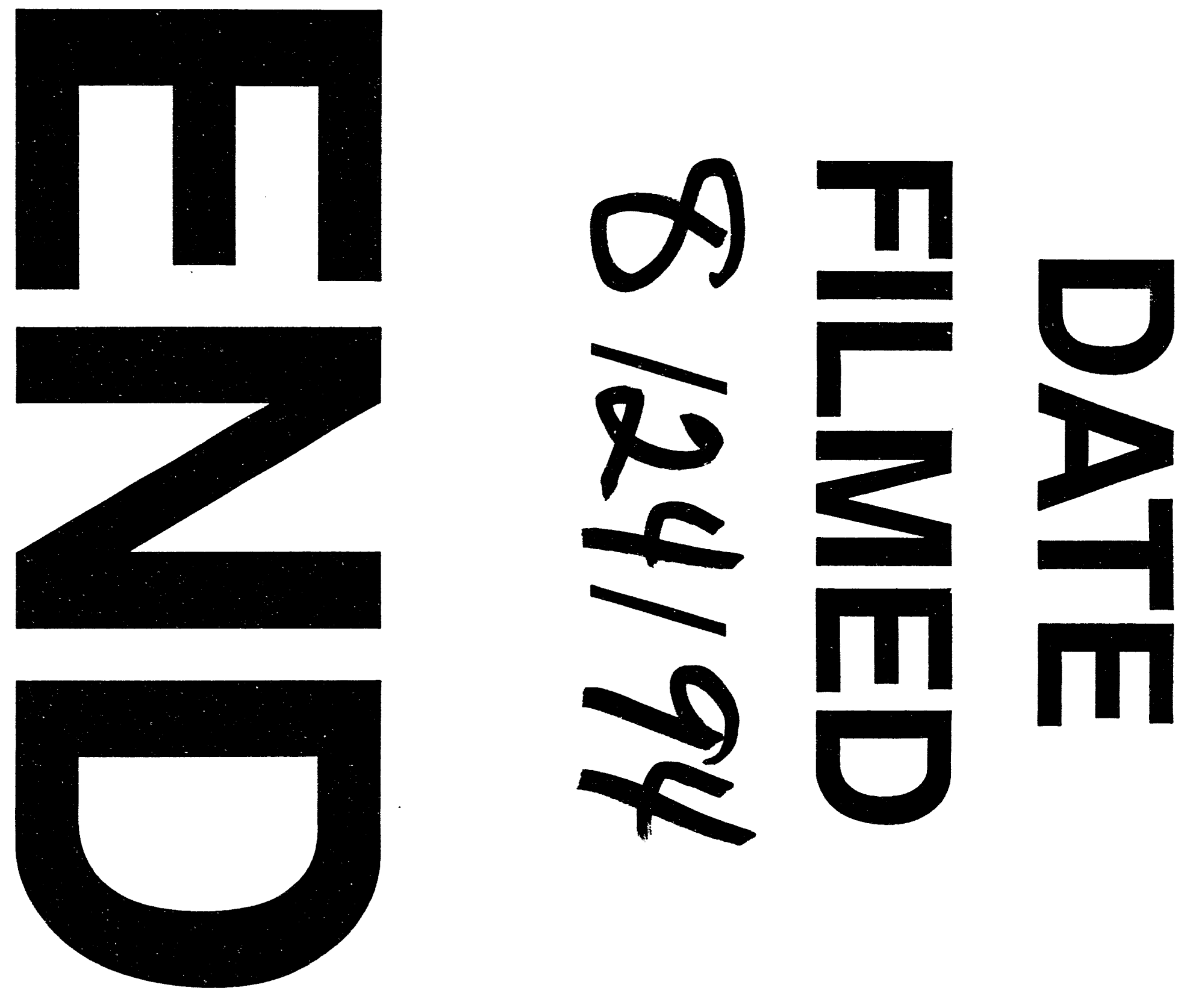


$$
1
$$

